\title{
CASE STUDIES \\ OF GEOTHERMAL LEASING AND DEVELOPMENT ON FEDERAL LANDS
}

Prepared for

\section{U.S. DEPARTMENT OF ENERGY}

JET PROPULSION IABORATORY CALIFORNIA INSTITUTE OF TECHNOLOGY PASADENA, CALIFORNIA 


\section{DISCLAIMER}

This report was prepared as an account of work sponsored by an agency of the United States Government. Neither the United States Government nor any agency Thereof, nor any of their employees, makes any warranty, express or implied, or assumes any legal liability or responsibility for the accuracy, completeness, or usefulness of any information, apparatus, product, or process disclosed, or represents that its use would not infringe privately owned rights. Reference herein to any specific commercial product, process, or service by trade name, trademark, manufacturer, or otherwise does not necessarily constitute or imply its endorsement, recommendation, or favoring by the United States Government or any agency thereof. The views and opinions of authors expressed herein do not necessarily state or reflect those of the United States Government or any agency thereof. 


\section{DISCLAIMER}

Portions of this document may be illegible in electronic image products. Images are produced from the best available original document. 


\title{
$5030-256$
}

\section{CASE STUDIES OF GEOTHERMAL LEASING AND DEVELOPMENT ON FEDERAL LANDS}

September 29, 1978

\author{
Marc Trumme1 \\ Prepared for \\ U.S. Department of Energy \\ Division of Geothermal Energy
}

JET PROPULSION LABORATORY CALIFORNIA INSTITUTE OF TECHNOLOGY PASADENA, CALIFORNIA 
CONTENTS

$\underline{\text { Page }}$

I. INTRODUCTION -

II. SUMMARY -

III. OVERVIEW OF PERMITTING/LEASING IMPLICATIONS OF CASE
STUDIES - 3-1

A. STARTING DELAYS - 3-1

B. PHASED DEVELOPMENT - 3-1

C. JOINT ACTION (FEDERAL, STATE, LOCAL) - 3-2

D. FULL FIELD WELL PERMITTING - 3-2

IV.

CASE STUDIES -

A. ISLAND PARK - 4-1

B. ROOSEVELT HOT SPRINGS -

C. MOUNT HOOD NATIONAL FOREST - 4-8

D. MONO-LONG VALLEY - 4-12

E. cosО НОТ SPRINGS - 4-24

F. IMPERIAL VALLEY - 4-30

G. THE GEYERS -

\section{Figures}

IV B-1 Map of the Roosevelt Hot Springs area showing --- 4-7 Getty's proposed access routes and wells, other major approved geothermal activities of Phillips Petroleum Co, , and the Unit Area boundary

IV D-1 Mono-Long Valley KGRA $4-14$

IV D-2 Long Valley (Mammoth) Geotherma1 Study Area -- - 4-16

IV D-3 Mammoth-Mono Land Use Plan - Alternative 3 -_-_-_ 4-19

IV D-4 Mammoth-Mono Land Use Plan - Alternative $4 \ldots-\ldots-20$

IV D-5 Mammoth-Mono Land Use Plan - Alternative 5 -

IV D-6 Mammoth-Mono Land Use Plan - Alternative 6 -_--- 4-23 
IV E-1 Coso Hot Springs KGRA and Study Area

4-26

IV G-1 BLM Mineral Reserve Lands to be Leased

$4-32$

Tables

II-1

Geothermal Case Study Summary

$2-2$

IV B-1 Roosevelt Hot Springs Non-Competitive Geothermal Leases $(6-21-78)$

4-6

IV C-1 Mount Hood Planning Unit Leases Issued

May 24, 1978

4-11

IV E-1 Coso: Non-Competitive Lease Applications --_-_ 4-27 
SECTION I

INTRODUCTION

In response to a widely expressed need to examine the impact of the federal regulatory system on the rate of geothermal power development, the Department of Energy - Division of Geothermal Energy (DGE) has established a Streamlining Task Force in cooperation with appropriate federal agencies. The intent is to find a way of speeding development by modification of existing laws or regulations or by better understanding and mechanization of the existing ones. The initial focus was on the leasing and development of federal lands. How do the existing processes work? Would changes produce positive results in a variety of cases? These are questions which must be considered in a national streamlining process.

This report presents case studies of federal leasing actions on seven diverse locations in the western region. Characteristics of existing high geothermal potential areas are quite diverse; geography, environment, industry interest and the attitudes and activities of the responsible federal land management agencies and the interested public vary widely. Included are descriptions of post and current activities in leasing exploration and development and discussions of the probable future direction of activities based on current plans. Implications of these plans are presented.

The case studies were based on field interviews with the appropriate State and District BLM officer and with the regional forester's office and the particular forest office. Documentation was utilized to the extent possible and has been included in whole or in part in appendicies as appropriate. 


\section{SECTION II}

\section{SUMMARY}

Table II-1 summarizes the case studies. The various cases have several common threads:

- On Forest Service (FS) 1and a 2 to 3 years period was required to start the environmental document preparation. This was due to lack of staff and funding and due to the FS not having full knowledge of the possible impact of geothermal development on their high recreational-use areas. Also evident is a general FS concern of their lack of control of the development process after full development leases are let.

- A similar (to FS land) lengthy start condition resulted at Coso due to Navy concerns of the impact of development on the primary mission of the Naval Weapons Center (NWC) at China Lake. First lease applications in the area were in early 1974--the contract for EIS preparation was let in September 1978.

In areas with heavy recreational use or high public visibility (FS 1and at Mt. Hood, Island Park and Mono-Long Valley) and at Coso (where the Navy is concerned about maintaining its primary milltary mission capability), the FS and Navy are reluctant to "relinquish control" over development on large blocks of land for extended perlods of time. The reluctance is manifest in different ways all of which result in a phased form of development: at Mt. Hood the leases. include a NSO stipulation with FS step-by-step approval of each phase of exploration and upon confirmation of a resource the need for a site specific EIS for a power plant; at Island Park a "less sensitive" area will be leased for full development while other possible geothermal development areas will not be leased or will be leased with NSO stipulation; at Mono-Long Valley only a part of the land "possibly" available for development will be considered for lease; at Coso the Navy plans a power plant of their own on "fee land" with other development to await its data gathering. In all of these cases, exploration for and quantification of the total areas possible resource as well as. future actual development could be delayed. 
Table II-1. Geothermal Case Study Summary

\begin{tabular}{|c|c|c|c|c|c|c|}
\hline & Area & Description & $\begin{array}{l}\text { Land Management } \\
\text { Responsibility }\end{array}$ & Leasing History & Current Activity & Future Development Imp1ications \\
\hline A & $\begin{array}{l}\text { Is land Park- } \\
\text { I daho }\end{array}$ & $\begin{array}{l}\text { A } 495,000 \text { A } \\
(450,000 \text { A Federa1) } \\
\text { ranges from forest } \\
\text { to scrub growth } \\
\text { adjolns sw corner } \\
\text { of Yellowstone } \\
\text { N.P. Includes: } \\
\text { Snake River water- } \\
\text { shed and Grizzly } \\
\text { Bean habitat. }\end{array}$ & $\begin{array}{l}\text { Large majority is in } \\
\text { Targhee N.F. small } \\
\text { portion in Gallitas } \\
\text { N.F. (Montana). BLM } \\
\text { manages small portion. }\end{array}$ & $\begin{array}{l}\text { 130 lease applications } \\
\text { in early } 1974 ; 200 \text { to date } \\
\text { Overlapping epplication } \\
\text { formed KGRA. Started area } \\
\text { wide EIS In late } 1976-- \\
\text { to be complete Jan. } \\
1979 . \text { No leasing to } \\
\text { date. FS feels area is } \\
\text { sensitive and requires } \\
\text { careful study and } \\
\text { public participation. }\end{array}$ & $\begin{array}{l}\text { Area wide EIS in } \\
\text { process. It } \\
\text { will recommend } \\
\text { leasing plan. A } \\
\text { "phased" plan is } \\
\text { probable. It } \\
\text { will select one } \\
\text { area (less } \\
\text { environmentally } \\
\text { sensitive w1th a } \\
\text { probable } \\
\text { resource) Leasing } \\
\text { and exploration/ } \\
\text { development on } \\
\text { other acceptable } \\
\text { lands would } \\
\text { awa1t experience. }\end{array}$ & $\begin{array}{l}\text { No resource has been confirmed yet. } \\
\text { Only one } 1000 \mathrm{ft} \text {. gradient hole has been } \\
\text { drilled on state land. Resource } \\
\text { confirmation and quantification would be } \\
\text { delayed by allowing development at only } \\
\text { one area. Leasing and deep hole drilling } \\
\text { should be allowed in other areas } \\
\text { concurrently with single location } \\
\text { development. The Targhee N.F. should } \\
\text { be assured of such a process remaining in } \\
\text { their control (thru 1nteraction with } \\
\text { U.S.G.S.). }\end{array}$ \\
\hline B & $\begin{array}{l}\text { Roosevel t Hot } \\
\text { Springs - Utah }\end{array}$ & $\begin{array}{l}68,365 \text { A. Scrub } \\
\text { growth in Great } \\
\text { Basin desert. No } \\
\text { residential or } \\
\text { recreation facil- } \\
\text { ities } 13 \text { mi. NE of } \\
\text { Milford, Utah. }\end{array}$ & 48,484 A, BLM managed. & $\begin{array}{l}\text { First lease applica- } \\
\text { tions Jan. } 1974 \text { KGRA } \\
\text { leased m1d } 1974.15 \\
\text { N.c. leases issued to } \\
\text { date. NEPA satisfled } \\
\text { by wide area EAR's. } \\
\text { Public reaction } \\
\text { favors development. } \\
\text { Environmental } \\
\text { problems are minimal. }\end{array}$ & $\begin{array}{l}\text { Exploratory and } \\
\text { resource defini- } \\
\text { tion drilling is } \\
\text { continuing. Nine } \\
\text { wells drilled by } \\
\text { PhIllips; } 2 \text { In } \\
\text { progress. Activ- } \\
\text { 1ty also by. } \\
\text { Thermal Power. } \\
52 \text { MW power plant } \\
\text { planned. }\end{array}$ & $\begin{array}{l}\text { During initial leasing process BLM and } \\
\text { USGS differed on stipulations. GS felt } \\
\text { that many steps were unnecessary as they } \\
\text { would be covered by POO's and the EA's. } \\
\text { BLM wanted to mainteain land management } \\
\text { control (surface). BLAS-GS interface } \\
\text { must be clearly understood. Phillips } \\
\text { feels that } 3-6 \text { month approval for each } \\
\text { drilling or pipeline app1ication may } \\
\text { cause delays. Since area is relatively } \\
\text { homogenerous (on the surface) some form } \\
\text { of general POO and EA with specific } \\
\text { exceptions if required could speed } \\
\text { development. }\end{array}$ \\
\hline c & Mt. Hood-Oregon & $\begin{array}{l}633,000 \mathrm{~A} \text {. (four } \\
\text { Planning Units) } \\
\text { area surrounds } \\
\text { Mt. Hood and } \\
\text { includes. Nt. } \\
\text { Hood KGRA. } \\
\text { Forested with } \\
\text { heary recreational } \\
\text { and timber harvest- } \\
\text { 1ng use. }\end{array}$ & Mt. Hood N.F. & $\begin{array}{l}\text { First lease applica- } \\
\text { tions were in early } \\
1975 \text {. After Timberline } \\
\text { Lodge and Mt. Hood } \\
\text { PU EARs, ffive Mt. Hood } \\
\text { and one T.L. leases } \\
\text { were let by March } 1978 \\
\text { with non-surface } \\
\text { occupancy stipulations } \\
\text { About } 94 \text { leases are } \\
\text { pending in } 4 \mathrm{PU} \text { 's. }\end{array}$ & $\begin{array}{l}\text { The F.S. Is cow- } \\
\text { pleting a NSO EAR } \\
\text { for the Clackamns } \\
\text { PU followed by NSO } \\
\text { leasing. Explora- } \\
\text { tion and develop- } \\
\text { ment on all wSO } \\
\text { leases will require } \\
\text { step-by-step ap- } \\
\text { roval by FS (and } \\
\text { USGS). Full develop- } \\
\text { ment will require a } \\
\text { site specific EIS. }\end{array}$ & $\begin{array}{l}\text { The FS feels that a step-by-step approval } \\
\text { system will maintain their control of } \\
\text { development and result in the least delay } \\
\text { due to active environmentalist public } \\
\text { groups. For this phased system to work } \\
\text { (speedily) some regulatory frame work } \\
\text { understood by all parties is needed. } \\
\text { Industry pressure seems 1fte possibly due } \\
\text { to the Mt. Hood Interagency Geothermal } \\
\text { Assessment program }\end{array}$ \\
\hline
\end{tabular}


Table II-1. Geothermal Case Study Summary (Continuation 1)

\begin{tabular}{|c|c|c|c|c|c|c|}
\hline & Area & Description & $\begin{array}{r}\text { Land Management } \\
\text { Responsibility }\end{array}$ & Leasing His tory & Current Activity & Future Development Imp11cations \\
\hline D & $\begin{array}{l}\text { Mono-Long Valley- } \\
\text { Cal1f. }\end{array}$ & $\begin{array}{l}460,000 \mathrm{~A} \text {. Includes } \\
\text { forested and scrub } \\
\text { growth areas. It is } \\
\text { an area of high } \\
\text { recreational usage } \\
\text { (winter and summer) }\end{array}$ & $\begin{array}{l}\text { The Inyo N.F. manages } \\
290,000 \mathrm{~A} \text { and the BLM } \\
105,000 \mathrm{~A} . \text { The area of } \\
\text { most promise is in FS } \\
\text { land. }\end{array}$ & $\begin{array}{l}\text { The area of most inter- } \\
\text { est 1s In lit1gation } \\
\text { under "Grandfather } \\
\text { rites." The BLM put up } \\
7 \text { parcels for lease in } \\
\text { Jan. } 1974 \text { under a } \\
\text { programmatic EIS; } 3 \\
\text { were leased, } 2 \text { of the } \\
3 \text { are In "Grandfather } \\
\text { rites" 11tigation. } \\
\text { There are about } 13 \\
\text { leases pending. }\end{array}$ & $\begin{array}{l}\text { A draft of a land } \\
\text { Use P1an for the } \\
\text { Mono-Mammoth PU } \\
\text { has been 1ssued. } \\
\text { It recommends } \\
\text { allowing geother- } \\
\text { mal leases only in } \\
\text { a } 26,330 \text { A area } \\
\text { lncluding the } \\
\text { "Grandfather" } \\
\text { land. It 1s due } \\
\text { for final release } \\
\text { 1n late } 1978 \text {. A } \\
\text { geothermal EAR for } \\
\text { the } 26,330 A \text { is in } \\
\text { preparations (also } \\
\text { scheduled late } \\
\text { 1978). Leasing } \\
\text { start 1s expected } \\
\text { Jan-Feb. 1979. }\end{array}$ & $\begin{array}{l}\text { There is activity on private leases in } \\
\text { the Casa Diable area including a pilot } \\
\text { space heating and snow melt project. An } \\
\text { unsuccessful well was drilled on one } \\
\text { BLM Lease. The current FS program will } \\
\text { allow exploration and development on } \\
\text { selected locations In the EAR study } \\
\text { area; no activity is expected on the rest } \\
\text { of the KGRA. The extent of the resource } \\
\text { 1 } \text { not yet certain. To measure Its extent } \\
\text { and to lead to a timely development of the } \\
\text { areas whole potentlal it would be necessary } \\
\text { to at least permit exploration in areas } \\
\text { other than the current } 26,330 \text { A study } \\
\text { area. To change the FS land use plan in } \\
\text { the future (based on experience in the } \\
\text { current study area) could be very time } \\
\text { consuming }\end{array}$ \\
\hline E & Coso Hot Springs & $\begin{array}{l}80,000 \text { A. study area } \\
106,000 \text { A. KGRA. A } \\
\text { desert area. Most } \\
1 \text { s on the China } \\
\text { Lake Navy Weapons } \\
\text { center Including all } \\
\text { all of the most } \\
\text { promising land. }\end{array}$ & $\begin{array}{l}\text { Of the } 80,000 \mathrm{~A} \text {, study } \\
\text { area } 30,000 \text { are BLM } \\
\text { managed, } 47,000 \text { are } \\
\text { Navy withdrawn and } \\
3,000 \text { are Navy } \\
\text { acquired fee land. }\end{array}$ & $\begin{array}{l}58 \text { non-competitive } \\
\text { lease applications } \\
\text { have been received. } \\
\text { No leases let to date } \\
24 \text { applications } \\
\text { remain open. Leasing } \\
\text { was delayed pending an } \\
\text { environmental document } \\
\text { and a BLM-Navy agree- } \\
\text { ment. The Navy wishes } \\
\text { to protect it's } \\
\text { primary mission. A } \\
\text { BLM-Navy MOU is } \\
\text { 1mminent. }\end{array}$ & $\begin{array}{l}\text { A contract for an } \\
\text { EIS covering the } \\
80,000 \text { A. study } \\
\text { area w111 be } \\
\text { awarded in } \\
\text { September 1978. A } \\
\text { final w1ll be } \\
\text { distributed in } \\
\text { Apr. 1980. Lease } \\
\text { sale 1s scheduled } \\
\text { for Dec. 1980. } \\
\text { The Navy is pro- } \\
\text { ceeding with plans } \\
\text { for a } 25 \text { MW plant } \\
\text { on their fee } \\
\text { lands. }\end{array}$ & $\begin{array}{l}\text { The Navy favors what would be a phased } \\
\text { development program. Results from their } \\
\text { fee land would be used for decisions } \\
\text { regarding BLM leased land. Again this } \\
\text { type of development will be slower than } \\
\text { otherwise possible. Exploration and } \\
\text { development on other lands would speed } \\
\text { definition and possible development of } \\
\text { the resource. }\end{array}$ \\
\hline
\end{tabular}


Table II-1. Geothermal Case Study Summary (Continuation 2)

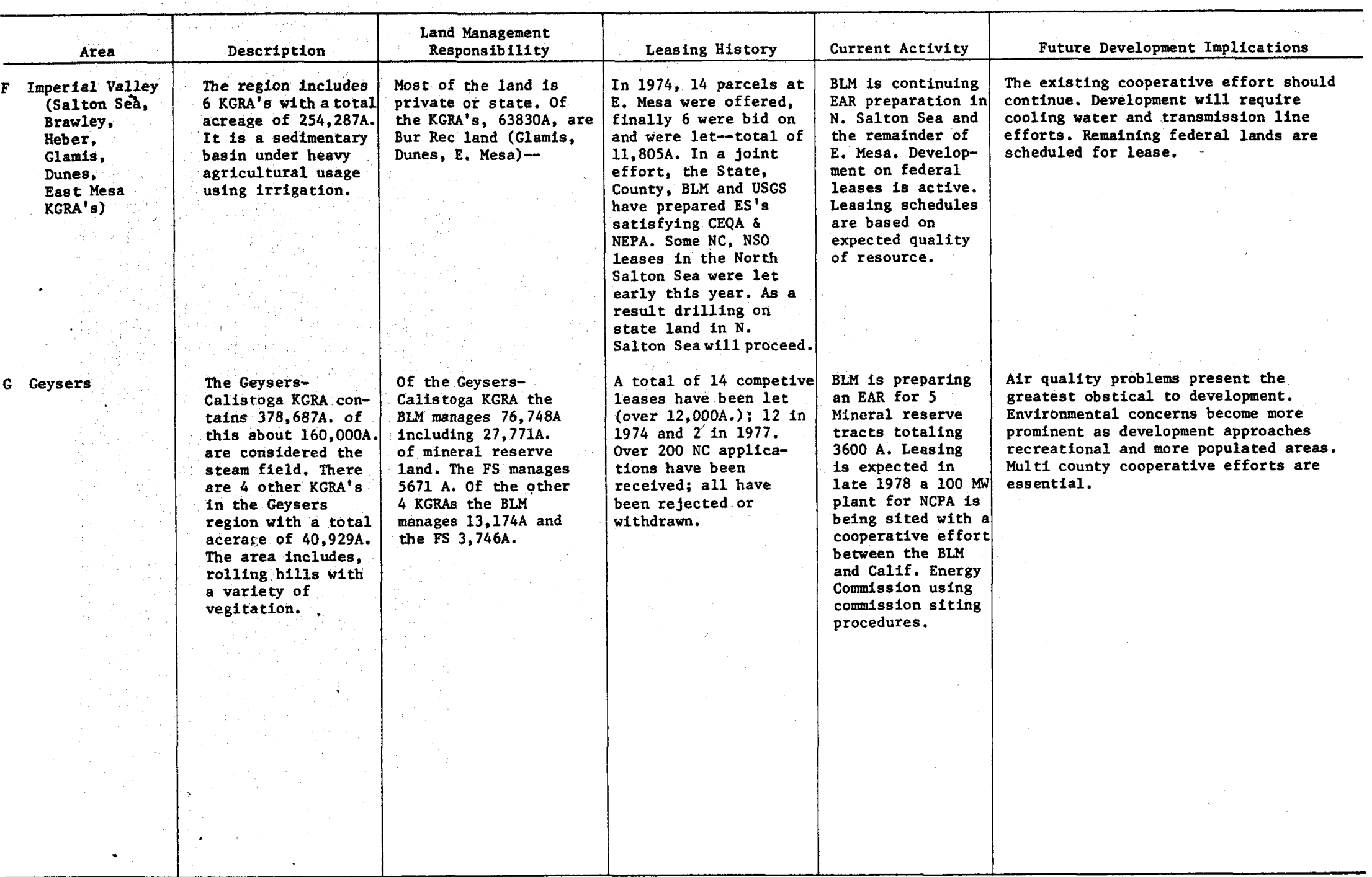


SECTION III

\author{
OVERVIEW OF PERMITTING/LEASING IMPLICATIONS \\ OF CASE STUDIES
}

\title{
A. STARTING DELAYS
}

- The post-1ease regulatory process relationship between the local land management agency and the USGS charged with regulating drilling operations and plant siting should be examined to see if the current process does allow the local agency sufficient control or if some changes are appropriate.

A relatively lengthy time was required to start the lease process on a11 FS lands and on the BLM/Navy land at Coso. The times were at least caused in part by a lack of knowledge of the full implications of geothermal development (in the case of the FS on their forest management plans and in the case of the Navy on their primary military mission). The FS, to paraphrase the opinion of one official, is reluctant to give up control of the forest to a 20 to 30 year geothermal power development without fully understanding the nature of such a development.

The FS did not feel that their land management role in the exploratory and development drilling and the plant siting phases was sufficient to assure control of total forest usage. This concern (and the Navy's similar concern) became manifest in the various forms of "phased" development discussed below.

The current process (FS approval of drilling EA's prepared by the USGS) does give the FS some control of development; they may not fully appreciate it or may desire a more active participation as the local land managers.

\section{B. PHASED DEVELOPMENT}

- In areas where phased development is implemented an available regulatory process that allows a controlled exploratory program on lands not under full development would permit the most timely definition of the extent of the resource and later full development of its potential.

Another result of an area specific geothermal development "experience gap" is the use of some form of phased development in areas with little or no previous geothermal development. The result is that full development will be permitted in a limited less-sensitive area with future development in other areas based on experience with its results: the impact could be a delay in exploring and defining the total resource and in developing its ultimate potential at a11 areas. 
C. JOINT ACTION (FEDERAL, STATE, LOCAL)

- In areas of mixed land (private, state, and federal) such as Imperial County a cooperative effort is essential to rapid development. Environmental documents should be written jointly to satisfy both federal and state requirements. County/local governments should be encouraged and aided to become active partners in development.

- The BLM approach in California of siting the NCPA plant at The Geysers by using State procedures and the California Energy Commission may be a method of procedure which results in maximum local cooperation.

D. FULL FIELD WELL PERMITTING

- In relatively homogeneous areas development could be speeded by not necessarily requiring new $\mathrm{POO}$ 's and EA for each well (or group of wells); a general POO and EA with specific exceptions as required might be feasible. 
SECTION IV

CASE STUDIES

\section{A. ISLAND PARK}

1. Summary

A five-year two-month period will elapse from the first 63 lease applications till the implementation of an EIS to permit leasing. Three years of that period was start-up time prior to EIS preparation. The reason for this three year period was the lack of Forest Service experience in Geothermal development and the obtaining of appropriate FS staff and funding.

The issue critical to timely development of the area will be the determination and implementation of a leasing and development policy that encourages both exploration for resource confirmation and powerplant development. If the FS uses a "phased" development approach the allowed activities within the region must be such that both exploration for resource confirmation over a wide area and a swift (as permitted by the EIS) development progression is possible.

\section{Area Description}

The Island Park study area consists of about 495,000 acres (450,00 Federa1) in an area west of the southern part of Yellowstone Park. It is mostly in the Targhee N.F. in Idaho with a small northern part in the Gallatin N.F. (Montana) and a small south-eastern portion in Wyoming. Some smaller portions of the federal land are BLM managed and there is some small amount of state land.

The area vegitation ranges from Pine Forest to scrub growth; it includes many streams, is a primary area for the Snake River watershed and included Grizzly Bear habitat and possibly other rare or endangered species concerns.

The proximity of Yellowstone Nationa1 Park and the possible sensitivity of its natural activity to commercial development in the Island Park area is also of concern.

\section{Leasing Background}

Over 130 lease applications in the area were received in the first ha1f of 1974; the total to date is almost 200 . There have been some withdrawals but most applications remain. Some of these applications are in the Yellowstone KGRA; others overlapped causing a new (Island Park) KGRA to be defined. Appendix A-1 (from an Island Park FS Progress Report - early 1977) summarizes the background of the process resulting in deciding to do an area wide EIS prior to leasing. The preparation of 
the EIS actually started in January 1977 with the formation of a study team. It is due for completion in January 1979 with implementation in Apri1 1979.

\section{Activities}

The schedule in Appendix A-2 summarizes the EIS preparation plans. The Targhee N.F. is the lead agency; a three man team is preparing the EIS for Targhee: Mickey Beland, Coordinator; John McGee, Biologist; and Stan Szczepanowski, Hydrologist. They are supported by an interagency team as 1isted in Appendix A-3.

The preparation consists of a year of data collection and planning followed by a year of writing and complex public and government agency reviews. The public review listed on the schedule (Appendix A-3) for 2/4/78 was actually conducted on March 18, 1978 (Appendix A-4). Mickey Beland feels they are "essentially" on schedule and will meet the completion dates.

Around six options are under consideration ranging from essentially no leasing to very liberal leasing. The final policy will include a land-use plan defining: areas precluded from any leasing; areas requiring a non-surface occupancy or limited activity lease; and areas which could be leased and developed subject to site specific EA approval by USGS and the FS, The timing or sequences of leases will also be defined. Possibilities range from opening all lands for lease simultaneously (as permitted by the land-use plan) to a "phased" lease plan opening selected areas for lease and development in a phased manner. The phased leasing plan would probably select an area containing high resource potential and low environmental impact for earliest development.

\section{Discussion}

a. EIS Preparation. There will be a five-year and two-month period between the first 63 lease app1ications $(1-31-74)$ and the start of implementing leasing $(4-5-79)$. of this, two years and three months will be required to prepare and implement an EIS; it took three years between the first lease applications (63 applications) and the starting of EIS preparation.

A summary of the development schedule is as follows:

\begin{tabular}{|c|c|}
\hline \multirow{2}{*}{\multicolumn{2}{|c|}{ First 63 lease applications received. }} \\
\hline & \\
\hline $4-30-74$ & Lease applications total 133 \\
\hline $5-\quad-74$ & Targhee Forest informed of lease app1ications \\
\hline$: 5-07-75$ & $\begin{array}{l}\text { Interagency meeting agrees on need for EIS - } \\
\text { target date } 1978 \text { for draft. Targhee N.F. } \\
\text { designated as lead agency. }\end{array}$ \\
\hline $7-11-75$ & $\begin{array}{l}\text { BLM notified lease applicants that an EIS } \\
\text { would be required to lease--to be complete } \\
\text { sometime in } 1978 \text {. }\end{array}$ \\
\hline
\end{tabular}




\begin{tabular}{|c|c|}
\hline $9-17-75$ & $\begin{array}{l}\text { Targhee Supervisor issues statement on } \\
\text { development plans to Senate Interior Sub- } \\
\text { Committee. }\end{array}$ \\
\hline $\begin{array}{r}9-\quad-76 \\
1-\quad-77 \\
12-01-77 \\
3-18-78 \\
4-13-78\end{array}$ & $\begin{array}{l}\text { EIS team begins to form--Mickey Beland becomes } \\
\text { Coordinator. Two additional FS Team Members } \\
\text { hired. } \\
\text { First Interagency meeting held. } \\
\text { Data gathering complete. } \\
\text { Public involvement session. } \\
\text { Public input analyzed. }\end{array}$ \\
\hline $\begin{array}{l}(6--78) * \\
(7-05-78) \\
(9-08-78) \\
(10-20-78) \\
(12-01-78) \\
(1-05-79) \\
(4-05-79)\end{array}$ & $\begin{array}{l}\text { Draft EIS complete. } \\
\text { Draft to interested public and CEQ. } \\
\text { Organizational meeting. } \\
\text { Complete final statement. } \\
\text { Final reviews. } \\
\text { File with CEQ and mail to interested public. } \\
\text { Implement recommendations. }\end{array}$ \\
\hline
\end{tabular}

*Parenthesis indicate scheduled dates.

The schedule shows that it took a year and one-ha1f to decide to prepare an EIS and another year and one-half to start it. The first year and one-half period was probably due to the (we11 discussed) FS inexperience with geothermal development and its implications. The second year and one-half period was taken up by some controversy following the EIS decision and the obtaining of funding and new FS personnel to prepare the document.

The schedule shows that on 9-17-75 George 01son, the Targhee Forest Supervisor testified to a Senate Sub-Committee committing the FS to a time table for EIS preparation (no earlier than 1978). He explained that the Island Park Land-Use Plan was in preparation and would contribute toward the EIS. He said that two (2) complete field seasons would be required for data gathering for the Land-Use P1an and EIS. He stated several times that plans were contingent on funding and staffing.

b. Development Plans. The nature and speed of future Island Park geothermal development depends on the leasing policy approved by the BLM and Forest Supervisors. What the policy will be is not certain in detail but it will certainly exclude much land from any development and will almost certainly indicate allowable power plant development in other areas (subject to future EA approval). Some areas may still be "gray"; future development in these gray areas might depend on "experIence" obtained in the development of the less impacted areas. There are several graduated options under consideration.

Recently the service has started considering a "phased" leasing approach. A higher probable resource and lower environmental 
impact would be selected and leased for development. Based on the experiences with development (and resource confirmation) in that area, other areas would be later opened for development. What to do with the areas outside the initial development area seems to still be a question; lease applications could be kept pending or non-surface occupancy (or limited activity) leases could be let.

c. Implications to Speedy Development. Central to the issue is the fact that a resource has not been confirmed. The FS would like a more thorough geologic analysis of the area (which still would require actual drilling for confirmation). To date only one 1,000 foot gradient hole has been drilled on state land at Railroad Ranch (Harriman State Park).

If one area is selected for initial development there should be a possibility for exploration activity on other areas. If the other areas are not leased the KGRA could be extended based on successfu1 drilling on the development area. If the other areas are leased the surface occupancy stipulations should encourage exploration to confirm a resource.

For speedy development at Island Park a leasing approach and leasing development procedure (with the USGS cooperation) is necessary that encourages and expedites both initial development and a wide-area exploration program.

\section{B. ROOSEVELT HOT SPRINGS}

\section{Summary}

The Roosevelt H.S. area received first priority by Utah BLM for geothermal leasing; the first Utah EAR was for this area. The KGRA (expanded by overlap) was leased in 1974 and some 15 additional noncompetitive leases were processed, starting January 31,1974 , in an average period of about 17 months.

There were some differences of opinion between the BLM and USGS on required stipulations with the USGS-AGS feeling that less stipulations were required since concerns could be controlled in $P O O$ and EA approvals. The BLM basically felt that surface stipulations were their concern and acted accordingly.

Phillips Petroleum is a major developer in the area at this date. They Indicated that development could possibly be speeded if there were some form of broader drilling approval not requiring a 3 to 6 month approval period for each specific well POO and EA.

\section{Area Description}

The Roosevelt Hot Springs area is in the Great Basin Desert about 13 miles N.E. of Milford, Utah, lying along the base of the Mineral 
Mountains. It's terrain is flat to slightly rolling with scrub vegitation. No residential or recreational facilities are included.

The EAR covers 68,365 acres including 48,484 acres administered by the BLM and 19,881 acres of state or private land. The original KGRA covered about 5,000 acres; it was enlarged by overlapping lease applications in early 1974 to about 24,000 acres.

\section{Leasing Background}

To support geothermal leasing the Utah BLM State office decided to prioritize their effort. Roosevelt H.S. was selected as the first priority and the first EAR was prepared for that area by the Filmore District office. Later EARs were prepared for Cove-Fort and Thermo H.S. and then two additional EARs for the intervening land.

The first non-competitive lease applications were received $1-31-74$ with the final application in the area by 1-15-75. The last lease was let by 7-1-76. There are now a total of 15 non-competitive leases 1 et.

The KGRA (as revised) was put up for lease sale in early 1974 with the bids due 7-30-74 (Appendix B-1). Special stipulations developed by the BLM-SO were included.

Stipulations were reviewed by the USGS-AGS with the general comment that many were unnecessary as they would be covered by $\mathrm{POO}^{\prime}$ 's and the required EA, for site operations; the BLM perservered and general (revised stipulations) were later developed (Appendix B-2).

\section{Activities}

a. Leasing. Table IV B-1 summarizes the non-competitive leasing activities. Total time for leasing averages about 17 months with individual times ranging from 12 to 23 months. Generally most of the time seemed to be taken by the negotiation of POO's with the applicant. The AGS responded relatively rapidly to requests for clear listings; a continual objection to the stipulations was made in many cases by the AGS but didn't seem to inordinately hold up leasing. of development.

The stipulations in the leases do not seem to be restrictive

b. Development. Phillips Petroleum Company, the major lease holder in the KGRA, has been the most active in development. They have drilled nine (9) wells with two additional in progress; a total of 22 wells are permitted at this date. Additionally there has been some activity by Thermal Power. A $52 \mathrm{MWe}$ power plant development by Roger International (power plant builder and owner) and Utah Power and Light (electricity purchase) is planned. Figure IV B-1 shows the well and pipe-1ine locations. 
Table IV B-1. Roosevelt Hot Springs Non-Competitive Geothermal Leases (6-21-78)

\begin{tabular}{|c|c|c|c|c|c|c|c|c|c|}
\hline Lease No. & App1lcant/Holder & Acreage & $\begin{array}{c}\text { Date } \\
\text { Application }\end{array}$ & To G.S. 1st CL & $\begin{array}{l}\text { Returned } \\
\text { to State } \\
\end{array}$ & To G.S. 2nd CL & Returned to State & \multicolumn{2}{|c|}{ Withdrawn/Rej/Issued } \\
\hline $\begin{array}{l}\text { U25239 } \\
\text { U25305 }\end{array}$ & $\begin{array}{l}\text { Chevron } \\
\text { Davon assigned to }\end{array}$ & 1304.55 & $1-31-74$ & & $2-01-74$ & $4-24-75$ & $5-13-75$ & Issued & $5-01-75$ \\
\hline & thermal and $0^{\prime}$ Brien & 2254 & $1-31-74$ & & $5-02-75$ & $10-06-75$ & $10-23-75$ & Issued & $11-01-75$ \\
\hline $\begin{array}{l}\text { U25580 } \\
\text { U25308 }\end{array}$ & $\begin{array}{l}\text { Gary Seltzer } \\
\text { Davon assigned to }\end{array}$ & 1285 & $2-07-74$ & & $3-01-74$ & & $6-17-75$ & Issued & $7-01-75$ \\
\hline U25585 & $\begin{array}{l}\text { thermal and } 0^{\prime} \text { Brien } \\
\text { Trevan windsor }\end{array}$ & $\begin{array}{l}1920 \\
1920\end{array}$ & $\begin{array}{l}1-31-74 \\
2-08-74\end{array}$ & & $\begin{array}{l}5-03-74 \\
3-01-74\end{array}$ & $10-06-75$ & $\begin{array}{r}10-23-75 \\
6-17-75\end{array}$ & $\begin{array}{l}\text { Issued } \\
\text { Issued }\end{array}$ & $\begin{array}{r}11-01-75 \\
7-01-75\end{array}$ \\
\hline $\begin{array}{l}\text { U25253 } \\
\text { U26266 } \\
\text { U26263 }\end{array}$ & $\begin{array}{l}\text { G/T Exp. Co. } \\
\text { Trevan Windsor } \\
\text { Hunt }\end{array}$ & $\begin{array}{r}640 \\
1949 \\
2544\end{array}$ & $\begin{array}{l}1-31-75 \\
5-31-74 \\
5-12-74\end{array}$ & $\begin{array}{l}3-24-75 \\
6-28-74\end{array}$ & $2-10-75$ & & $\begin{array}{l}6-26-75 \\
6-17-75\end{array}$ & $\begin{array}{l}\text { Issued } \\
\text { Issued } \\
\text { Withdrawn }\end{array}$ & $\begin{array}{l}7-03-75 \\
7-01-75 \\
8-29-75\end{array}$ \\
\hline $\begin{array}{l}\text { U31296 } \\
\text { U29441 }\end{array}$ & $\begin{array}{l}\text { Noeth Gillette } \\
\text { American Geological }\end{array}$ & 2560 & $9-15-75$ & & $10-17-75$ & $6-18-76$ & $6-21-76$ & Issued & $7-01-76$ \\
\hline $\begin{array}{l}\text { U25319 } \\
\text { U25320 }\end{array}$ & $\begin{array}{l}\text { Enterprises } \\
\text { Milton Fisher } \\
\text { Milton Fisher }\end{array}$ & $\begin{array}{l}1520 \\
1908 \\
1656\end{array}$ & $\begin{array}{l}2-27-75 \\
1-31-74 \\
1-31-74\end{array}$ & $4-7-75$ & $\begin{array}{l}4-16-75 \\
2-01-74\end{array}$ & $6-01-76$ & $\begin{array}{l}6-21-76 \\
6-17-75 \\
6-11-75\end{array}$ & $\begin{array}{l}\text { Issued } \\
\text { Issued } \\
\text { Issued }\end{array}$ & $\begin{array}{l}7-01-76 \\
7-01-75 \\
6-16-75\end{array}$ \\
\hline U25321 & Milton Fisher & 2157 & $1-31-74$ & & $2-01-74$ & $5-09-75$ & $6-02-75$ & Issued & $7-01-75$ \\
\hline $\begin{array}{l}\text { U25584 } \\
\text { U27426 }\end{array}$ & $\begin{array}{l}\text { Trevan Windson (GP) } \\
\text { Malcolm Justice }\end{array}$ & $\begin{array}{l}1920 \\
2182\end{array}$ & $\begin{array}{l}2-08-74 \\
7-10-74\end{array}$ & $9-03-74$ & $\begin{array}{l}3-01-74 \\
2-11-75\end{array}$ & $6-01-76$ & $\begin{array}{l}6-21-76 \\
6-11-75\end{array}$ & $\begin{array}{l}\text { Issued } \\
\text { Issued }\end{array}$ & $\begin{array}{l}7-01-76 \\
7-01-75\end{array}$ \\
\hline U25332 & o'Brien Resources & 702 & $1-31-74$ & . & $2-01-74$ & . & $6-13-75$ & Issued & $11-01-75$ \\
\hline
\end{tabular}




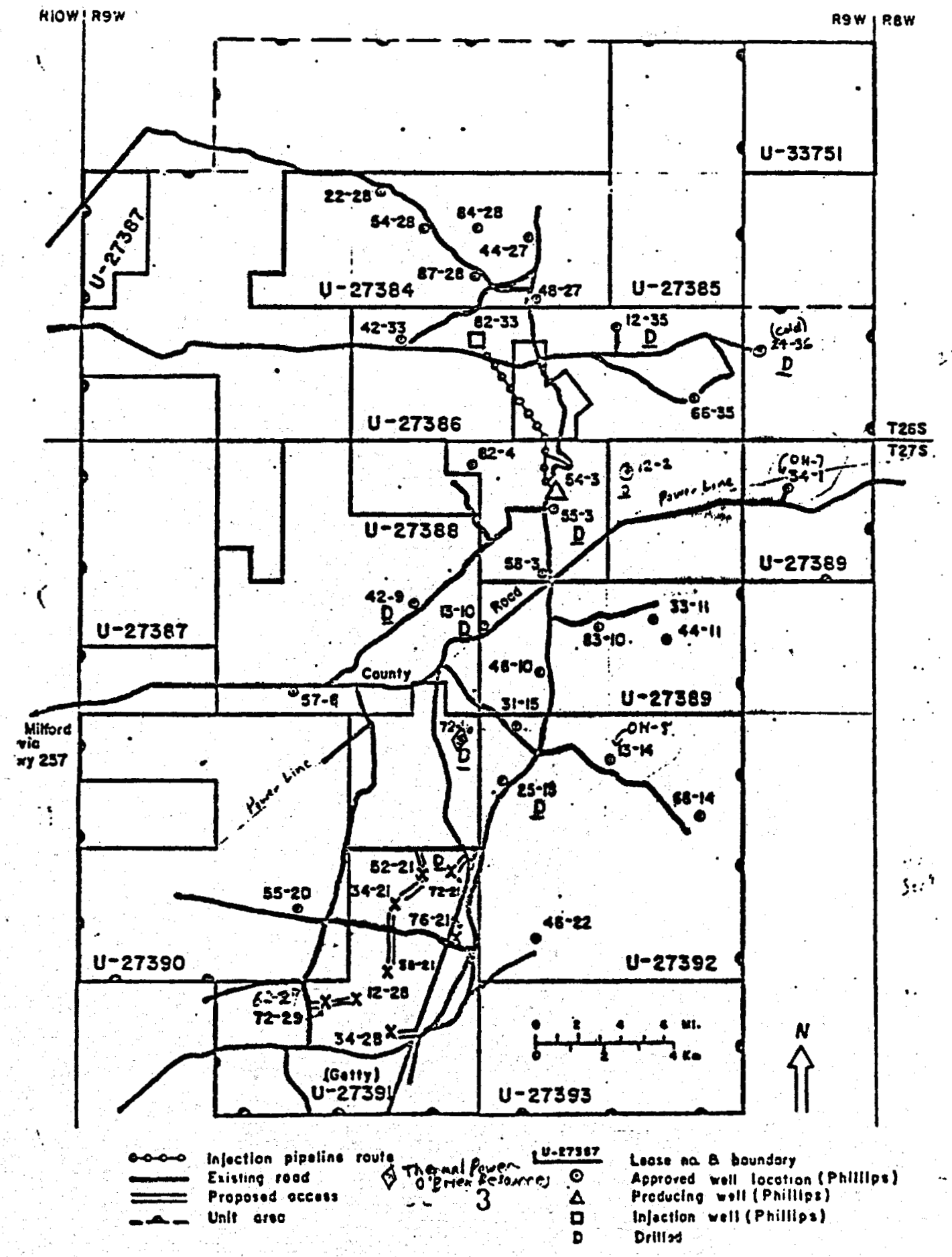

Figure IV B-1. Map of the Rooseve1t Hot Springs area showing Getty's proposed access routes and wells, other major approved geothermal activities of Phillips Petroleum Co., and the Unit Area boundary. 
Phillips (Don Harban) states that a three to six months period is required for approval by the AGS of each drilling activity and pipe-line plan. They indicate that this requirement for each individual activity can cause some delay in development.

\section{Discussion}

The Roosevelt area was the first to be leased by Utah. Given this fact, leasing seemed to have progressed reasonably promptly.

Phillips has been the most active developer in the area. They feel that the major factor slowing the speed of development is the need for a POO and EA approval on each specific action. They indicate a three to six month period is required for each approval. Perhaps it would speed, or have speeded, development if there were an agreed upon "standard" POO and approved EA for the area with specific deviations if required approved (in an expedicious manner); or perhaps, alternately an area wide well-drilling EA with some specific approvals required for each well.

This particular area seems amenable to area wide treatment since it is relatively homogeneous (surface) and does not present particular environmental problems.

\section{MT. HOOD NATIONAL FOREST}

\section{Summary}

Leasing in the Mt. Hood National Forest is controlled by the Forest Services' decision to use non-surface occupancy (NSO) 1eases with closely controlled, step-by-step development. Upon discovery and proof of a developable resource, a site and development-specific EIS would be written with the USGS (at this writing the USGS-AGS has not concurred with this plan).

Leasing in the Mt. Hood PU started when this decision was made and NSO leasing should be complete on the Mt. Hood and Clackamus F.S. Planning Units by late this year.

Industry seems content with this slow development, possibly just "reserving land", until the Mt. Hood Interagency Geothermal Assessment confirms (or denies) a resource.

Once pressure to proceed with exploration and development starts, expeditlous progress will depend on a timely, and well defined process for the successive steps in the development procedure. Delays are possible if the FS and GS do not work closely together in an environmental review process of each "new" operation plan. 


\section{Leasing Activity Background}

Leasing activity is non-competitive in the Mt. Hood National Forest land surrounding the Mt. Hood KGRA; the KGRA itself is essentially the top-of-the mountain and may never, or certainly not rapidly, be developed due to its physical and weather characteristics.

a. Mt. Hood Planning Unit. The first lease applications in the area were in the Mt. Hood Land-Use Planning Unit (west of the mountain) in February and March of 1975. Between November 1977 and January 1978 five leases were let (eventually assigned) to the North West Natural Gas Co. (NWNG). Four leases west of the mountain were applied for in November 1976 by Portland General Electric (PGE) and were let in March 1978. One lease, near Timerland Lodge south of the mountain, was applied for in March 1976 and let (with partial refection) in August 1977. Two leases are being appealed to the Interior Board of Land Appeals by G.P. Davidson. About 15 leases are pending while about 15 have been rejected or withdrawn.

b. Clackamus Planning Unit. There are currently 67 lease applications in Clackamus and no (zero) leases have been issued to date.

c. Bu11 Run Planning Unit. Three applications are pending in this unit (partially in Mt. Hood). Activity has been held up by the courts with resolution by recent congressional action (95200).

d. Lava - Eight-Mile White River Planning Unit. There are 18 lease applications pending in this unit; none let to date.

e. Current-Lease Descriptions. There are basically three leasing patterns in the Mt. Hood PU: the Timberline Lodge Lease planned for space heating of the Lodge and two larger lease areas at 0ld Maid Flats by the NWNG Co. (five leases) and on the east side of the mountain by Portland General Electric (four leases). NWNG plans to pipe $160^{\circ} \mathrm{F}$ hot water over a $50 \mathrm{~km}$ line to Portland for heating: PG\&E probably intends electric production.

The nature of the lease stipulations (discussed in Section IV-4) is such that any activity beyond non-surface occupancy (NSO) must be approved by the Forest Supervisor and the USGS-AGS.

Any power plant development work on full field development will require a full EIS by the FS and a site specific EA by the USGS (or a single cooperative document).

\section{Agency Responsibilities}

Since the land is within a National Forest the Mt. Hood Forest Supervisor has assumed the lead for environmental studies and stipulations 
with the USGS-AGS assistance and concurrance in the stipulations. The BLM-SO serves as the leasing agent.

\section{Forest Service Activities}

Until 1977 leasing was delayed since the FS had not decided on a policy for geothermal leasing. This was due in part to the previously reported "newness" of non-renewable resource management to the service and the lack of a "geothermally" experienced staff. In addition, the Mt. Hood forest was felt (by the FS) to present some unique considerations due to its high visibility and the great interest and involvement of public environmentalist and conservationalist groups.

a. Mt. Hood PU - Timberline Lodge (OR 15686). On June 24, 1977 an EAR for this specific lease was approved. It considered the impact of drilling (up to $4000 \mathrm{ft}$.) wells for use in obtaining hot-water for space heating of the Lodge. Special stipulations with the lease are included in Appendix C-1. USGS-AGS and FS approval of specific Plans of Operation (through EA) were also required. This lease was applied for on March 25, 1976 and was issued effective September 1, 1977.

b. Other Mt. Hood PU Leases. Or October 19, 1977 an EAR for NSO leasing in the FS Mt. Hood PU was approved. Special stipulations for leases under this EAR were developed and concurred with by the AGS on November 17, 1977. (Appendix C-2) On December 6, 1977 the Mt. Hood FS cleared 12 leases for issuance with the NSO requirement and the special stipulations. Six leases were not to be offered at that time; on six leases part were not to be leased. The BLM SO issued eight leases (Table IV C-1): two leases are under appea1. The BLM-SO and Mt. Hood Forest are continuing the leasing activity. John Geyer of the Mt. Hood Forest expects all (acceptable) leases in the Mt. Hood PU to be let by late this summer (the FS will exclude leases not developable due to terrain or being in a wilderness area, etc.).

Item 1,4 and 5 in the stipulation (Appendix C-2) have been satisfied and will be used in allowing further leasing. Items 2 and 3 will in reality continue and will be used to control exploration and development (see 5a).

c. Other Planning Units. John Geyer (FS Mt. Hood) plans to complete a NSO-EAR for the Clackamus PU by late 1978; at that point NSO leasing of Clackamus will proceed. Leasing on the other 2 PU's are further off. (Bull Run and 8 mile White River.)

d. Forest Service Land Management Plan (LMP). The LMP for Mt. Hood PU Is complete; the Clackamus LMP is due next year; unlike the Mt. Hood LMP it will include a "typical" EIS outline for a flashed-steam power plant. The FS feels that the LMP's (10-15 year effective 1ife) 
Table IV C-1. Mt. Hood Planning Unit Leases Issued

May 24, 1978

\begin{tabular}{|c|c|c|c|c|c|}
\hline Leasee & Number & Acres & $\begin{array}{c}\text { Date } \\
\text { Applied }\end{array}$ & $\begin{array}{l}\text { Date } \\
\text { Signed } \\
\text { for US }\end{array}$ & $\begin{array}{l}\text { Eff. Date } \\
\text { of Lease }\end{array}$ \\
\hline P. G. \& E. & $\begin{array}{ll}\text { OR } & 17050 \\
\text { OR } & 17054 \\
\text { OR } & 17055 \\
\text { OR } & 17056\end{array}$ & $\begin{array}{l}2560 \\
2620 \\
1900 \\
1923\end{array}$ & $\begin{array}{l}11-04-76 \\
11-04-76 \\
11-04-76 \\
11-04-76\end{array}$ & $03-08-78$ & $04-01-78$ \\
\hline $\begin{array}{l}\text { Alaska Pacific } \\
\text { Lumber to NWNG }\end{array}$ & OR 15503 & 2560 & $02-26-76$ & $03-17-78$ & $04-01-78$ \\
\hline $\begin{array}{l}\text { Max Millis } \\
\text { to NWNG }\end{array}$ & $\begin{array}{l}\text { OR } 14202 \\
\text { OR } 14204\end{array}$ & $\begin{array}{l}2560 \\
2604\end{array}$ & $\begin{array}{l}03-31-75 \\
03-31-75\end{array}$ & $\begin{array}{l}01-24-78 \\
01-24-78\end{array}$ & $\begin{array}{l}01-01-78 \\
01-01-78\end{array}$ \\
\hline $\begin{array}{l}\text { John Hook } \\
\text { to NWNG }\end{array}$ & $\begin{array}{ll}\text { OR } & 13993 \\
\text { OR } & 13994\end{array}$ & $\begin{array}{l}2560 \\
2560\end{array}$ & $\begin{array}{l}02-28-75 \\
03-10-75\end{array}$ & $\begin{array}{l}11-30-77 \\
11-30-77\end{array}$ & $\begin{array}{l}11-01-77 \\
11-01-77\end{array}$ \\
\hline $\begin{array}{l}\text { RLK \& Co. to } \\
W^{\prime} \text { East }\end{array}$ & OR 15686 & 589 & $03-25-76$ & $09-16-77$ & $09-01-77$ \\
\hline
\end{tabular}

are a foundation document and will assist EIS preparation following an application for site specific development.

\section{Discussion}

a. Mt. Hood FS Approva1. The Mt. Hood Forest has adopted the use of a NSO lease with controlled (by FS and USGS) exploration. If a developable resource is discovered they would then (with USGS) prepare a EIS specific to the site and to the nature of planned development.

They feel that an all-inclusive area-wide EIS would not work in the Mt. Hood Forest due to the high visibility of the forest and the active interest of the public groups.*

An area wide EIS would have to consider many types of development in all possible areas thus raising many significant environmental issues that might not occur if EIS's were related only to specific locations and to specific types of development.

*Sierra C1ub, Oregon Environmental Council, Mazamas, Friends of the Earth, Portland Advocates of the Wilderness, 1000 Friends of Oregon, etc. 
They feel the step-by-step NSo lease approach (keeping the public informed at all stages) will result in the most rapid and orderly development with the best long-term management of the forest. This approach would tend to assure the public that the FS was managing the forest "locally" for the maximum benefit of both local and national needs.

b. Exploration Under NSO Leases. Clearly, to prove a commercially developable resource, more than shallow wells are needed. The FS w111, with the USGS, need to permit (on a well-by-well basis) exploratory drilling to increasing depths and with increasing surface impacts. They will do this on a site-specific basis (an EA for each plan-of-operation). Lease applications on clearly undevelopable land have been denied but with the required site-specific studies of environmental impacts it may be found at a later date that other leases cannot be developed.

The Mt. Hood FS feels that development must continue with careful step-by-step control of each action due to the lack of experience in drilling (and managing drilling) on sites such as those found at Mt. Hood (unstable land and young volcanics).

c. Reaction of Developers. The developers seem content with slow development at this point. This may be due to the ongoing Mt. Hood Interagency Geothermal Assessment due to be completed in 1979. Their current leases are holding reserved space on what may be proved to be a valuable resource; at that point they might become more active in deve1opment.

d. Drilling Activities. Some shallow drilling has gone on the Timberline Lodge Lease (wells collapsed): new efforts to drill there are expected.

An $1800 \mathrm{ft}$. hole has been drilled on the NWNG leases in 01d Maid Flats. The hole will be drilled to $4000 \mathrm{ft}$. this year with Federal funding.

e. Speeding Development. The development of this area could best be aided by a well understood development and environmental approval procedure that would satisfy the FS desires for controlled step-wise development and the developers needs for a well defined clear orderly process. The integration of FS and USGS responsibilities needs to be well defined.

\section{MONO-LONG VALLEY}

\section{Summary}

The majority of the geothermally interesting land in the Mono-Long Valley region is managed by the U.S. Forest Service. Since first contact with the FS by the BLM in June 1973 for help in preparing a 
programmatic EIS until the expected start of leasing in the FS managed grandfather area of Long Valley will have taken five years and eight months.

As in the cases of the other FS managed areas, much time (two years) was taken up by adapting a FS "position" and acquiring staff, funding, and geothermal experience.

In July 1976 the Inyo forest started an EAR for a 26,330 acre parcel including the 16,730 acre grandfather lands. This document will identify the type of leasing allowed (or not allowed) with the required stipulations. Full development will be allowed in some areas; other areas will be leased with no surface occupancy stipulations; still other areas will not be leased at all.

The Regional Forester decided in October 1977 that the availability and suitability for leasing would be decided by a Land Management process as required by the National Forest Management Act. A draft of an Environmental Statement for Land Management in the Mono-Mammoth Planning Unit was distributed in July 1978. The draft recommends geothermal leasing only in the EAR study area. Leasing in this area is expected to start early in 1979 .

While the grandfather area is presently the highest interest region, there is a possible resource in other areas. The FS could change its approved land use plan later to permit leasing in other areas based on experience in the approved area; however, to avoid extended delay and to allow timely definition of the available resource, some form of leasing or permitting for exploration on other lands in the planning unit (not clearly unavailable for development) would be more effective.

\section{Area Description}

The Mono-Long Valley KGRA (figure IV D-1) consists of about 460,000 acres (290,000 USFS, 105,000 BLM, and 65,000 state and private). It includes a full range of terrain from mountain and forest to high desert (Great Basin).

Although sparsely populated, it is a heavily used recreation area both in summer and winter. Many local residents are sensitive to any development and are concerned with maintaining the environmental character of the area.

The area is of significant archaeological interest due to a history of Native American occupation. It is also of current cultural interest to the contemporary Native Americans.

Also of concern is noise pollution, particulate air pollution, and the exaggeration of winter fogs over Lake Crowley. 


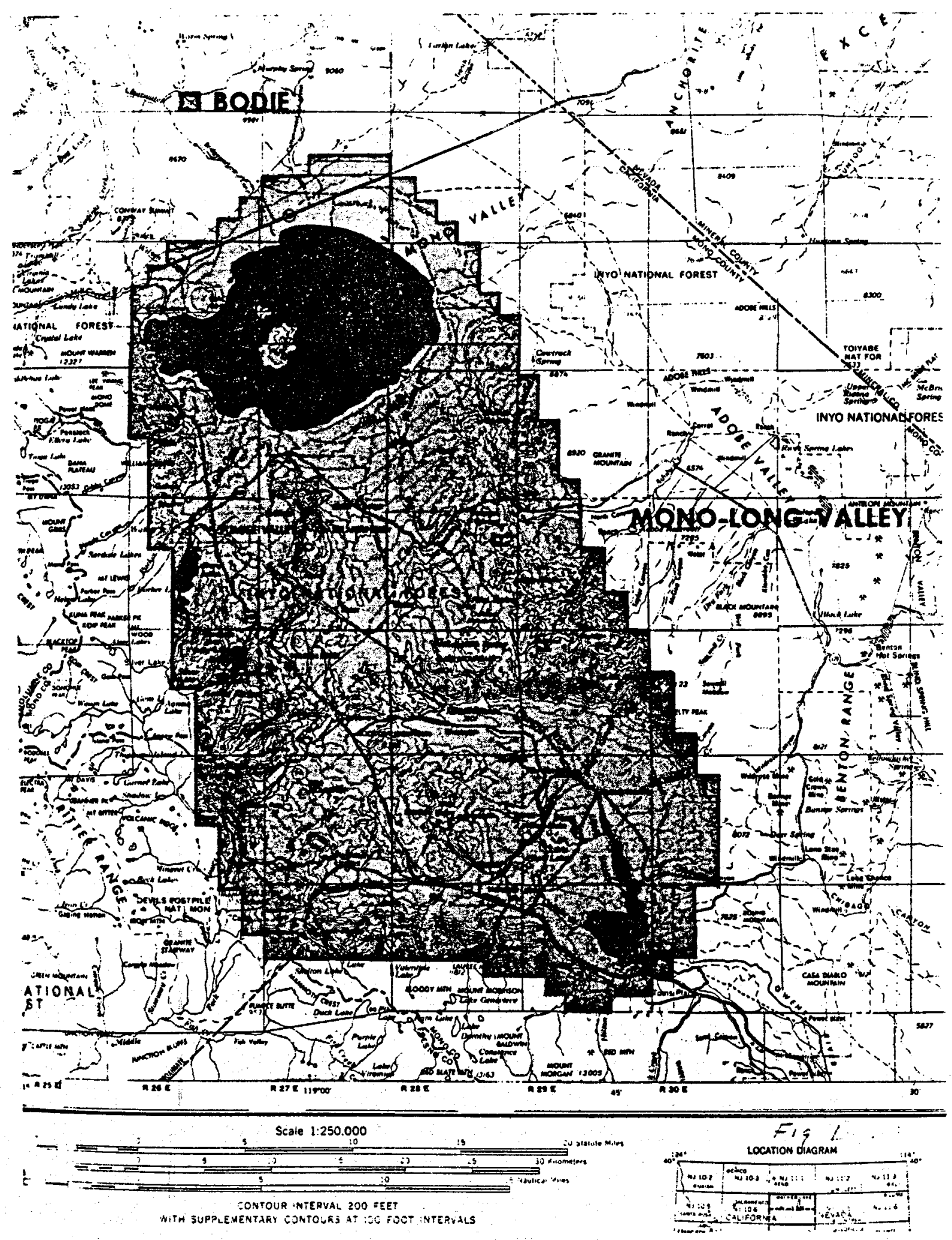

Figure IV D-1. Mono-Long Valley KGRA 
3. Leasing Background

In January 1974 the BLM put seven parcels northwest of Lake Crowley up for bid under a programmatic EIS completed October 1973; they received a total of ten bids on three tracts. Figure IV D-2 shows the three tracts; 1 and 2 are in litigation involving grandfather rights under the 1872 Mining Law.

Applications for grandfather rights lease conversions under the Steam Act have also been received for the "grandfather rights" area of the FS land and for a parcel in Mono Lake. Four applications in the John Muir Wilderness Area southwest of Lake Crowley were later withdrawn. There are ten applications pending on land south and east of Lake Crowley. There are two pending applications within the "grandfather rights" area.

Union Oil has leased a small parcel of private 1and (the "Clay Pit") in Little Antelope Valley in the middle of the grandfather area (figure IV D-2). They plan no significant exploration activity until surrounding lease sales occur.

Magma Power also holds private leases in the Casa Diablo area.

\section{Activities}

The activities and related events are summarized by the table in Appendix D-1. From the initial contact by the BLM requesting help on a programmatic EIS (June 1973) until the start of leasing (February 1979) will ultimately take five years and eight months. Two years (to June 1975) were occupied in deciding position and policy and acquiring staff and funds.

Air quality and archaeological surveys started June and July 1975. Archaeological studies were restarted (under a new contract) July 1976 and completed September 1976.

In October 1977 the Regional Forester decided that the suitability of land for geothermal leasing would be decided by the Land Management Planning Process with specific areas and stipulations determined through an EAR. This decision was based on requirements of the National Forest Management Act (passed November 1976) and partially on public input obtained in October 1975. A review draft of this plan was distributed Ju1y 3,1978 . It is discussed in the following section.

A Geothermal leasing EAR started In July 1976 is scheduled for completion November 1978. The author has recently accepted a new position in the Angeles National Forest; replacing him (with the resultant hiring and training process ) could delay the completion of this document.

The EAR covers the grandfather clause area and some land to its north and west (figure IV-2). The preferred option of the draft Land Management plan assigns the identical area for geothermal leasing. 


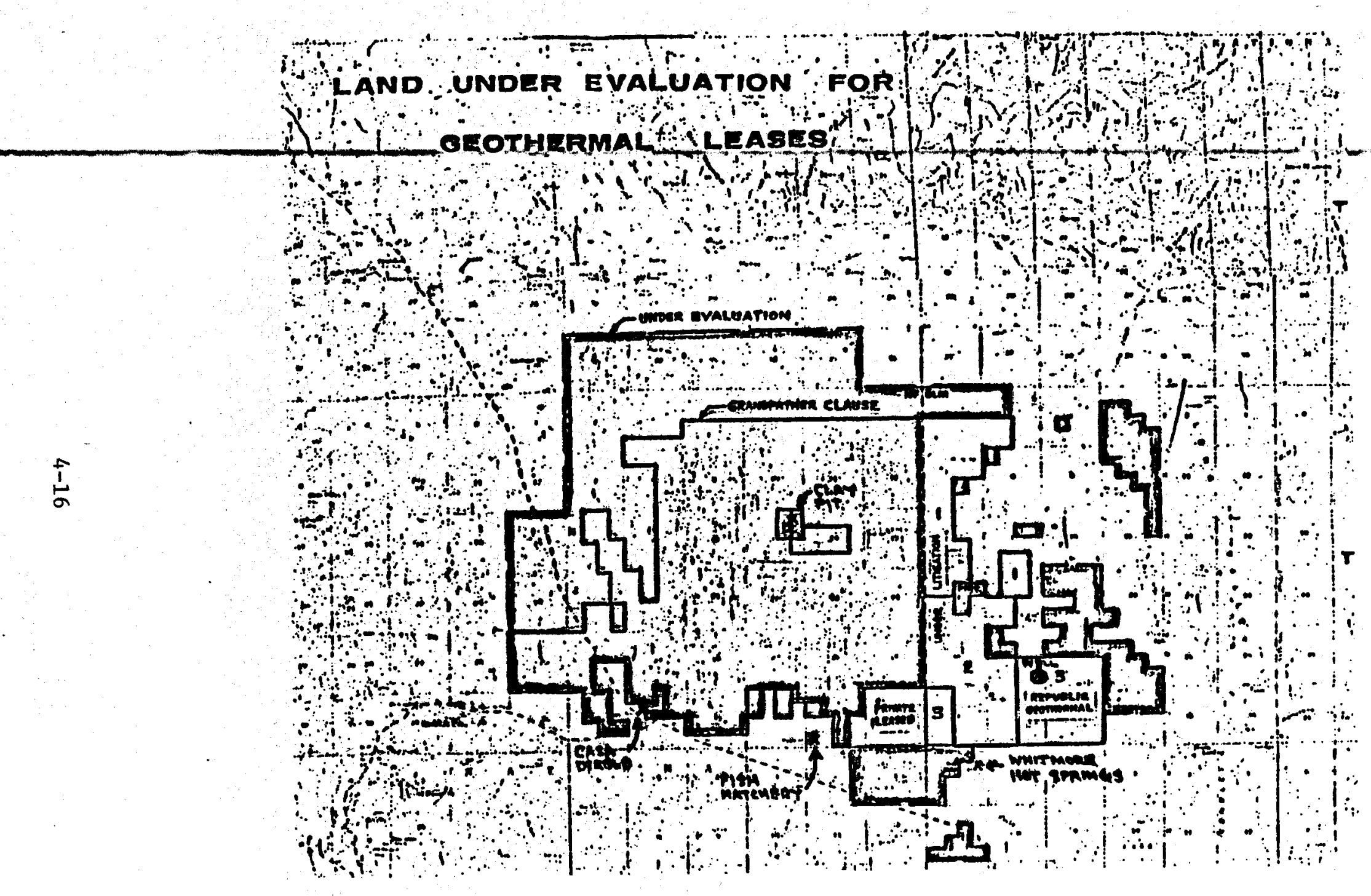

Figure IV D-2. Long Valley (Mammoth) Geothermal Study Area 


\section{Discussion}

As is true for other FS-managed geothermal regions discussed herein, the FS has taken a long period to "get started" on geothermal leasing. The reasons are also similar: 1ack of staff experienced with the implication of geothermal development, lack of funding, and, perhaps most significant, a high level of sensitivity to the possible impact of development on the recreational, environmental, cultural, and archaeological aspects of the region (particularly as reflected by the user and resident public reaction).

The process was stretched out by: the desire to consider county land use plans (Mono Plan), the soliciting of financial or other equivalent aid, and the decision to follow the land use planning requirements of the National Forest Management Act.

a. Land Use Plan. The Inyo Forest has prepared a land use plan called "USDA-Forest Service Environmental Statement Land Management Plan Mammoth-Mono Planning Unit". The draft was issued for comment July 3, 1978 , and is due for final issue October 1978.

The relative urgency and issues of main concern as stated in the Land Use Plan are quoted below.

"Relative Urgency of the Proposal

"The Mammoth-Mono Planning Unit (MMPU) is receiving priority attention because of the need to respond to an increasing number of environmental issues and concerns relating to competitive demands on National Forest lands. Many of the decistons to be made by private landholders and county administrators are contingent upon management directions taken by the Forest Service. The Inyo National Forest is also committed to an environmental statement as a followup to the Monoplan and the June Lake Loop General Plan.

"Issues of major concern in the MMPU are:

- Providing quality recreation opportunities, both winter and summer, commensurate with public demand and capabllity of the land to accommodate such activity

- Providing suitable lands for geothermal development which are commensurate with maintaining other resource values

- Acceptance of the Monoplan by the Forest Service

- Acceptance of the June Lake Loop General P1an by the Forest Service" 
(1) Land Management Alternatives. The plan evaluates (against each other) six land use alternatives based on the following criteria:

"Criterion 1: Dealing with issues of major concern.

Criterion 2. Contributing to RPA* goal attainment.

Criterion 3. Yielding outputs for contributing to

RPA target attainment.

Criterion 4. Passing tests of feasibility.

Criterion 5. Resulting in the least adverse environmental effects on the physical and biological environment.

Criterion 6. Resulting in the most beneficial changes in the social environment.

Criterion 7. Resulting in the highest economic growth."

The six alternate plans allow for geothermal leasing ranging from no specific considerations (Alt 1) and 16,730 acres (Alt 5) to 281,750 acres (Alt 2); Alternative 6 , the recommended one, allows leasing on 26,330 acres. The following are the six alternatives and the geothermal leasing implications:

Alt 1. Continues present management directions.

No specific geothermal considerations.

Alt 2. Permits geothermal development on all areas except wilderness areas and research areas. Existing winter sports areas limited to space heating geothermal development. Potential winter sports areas may. be developed for geothermal with winter sports development modifled not to interfere. No foreground geothermal development along highways 395, 120, iand 158.

Potential geothermal area 281,750 a

A1t 3. Large geothermal area - mostly east of Highway 395. NSO leases in Hot Creek and within existing or potential recreation sites that would degrade the desired experience level. Limits highway foreground view development.

Potential geothermal area 138,990 a (figure IV D-3)

Alt 4. Moderate geothermal area - NSo leasing near Hot Creek. Limits highway foreground view development.

Potential geothermal area 55,900 a (figure IV D-4)

* Forest and Rangelands Renewable Resource Planning Act 


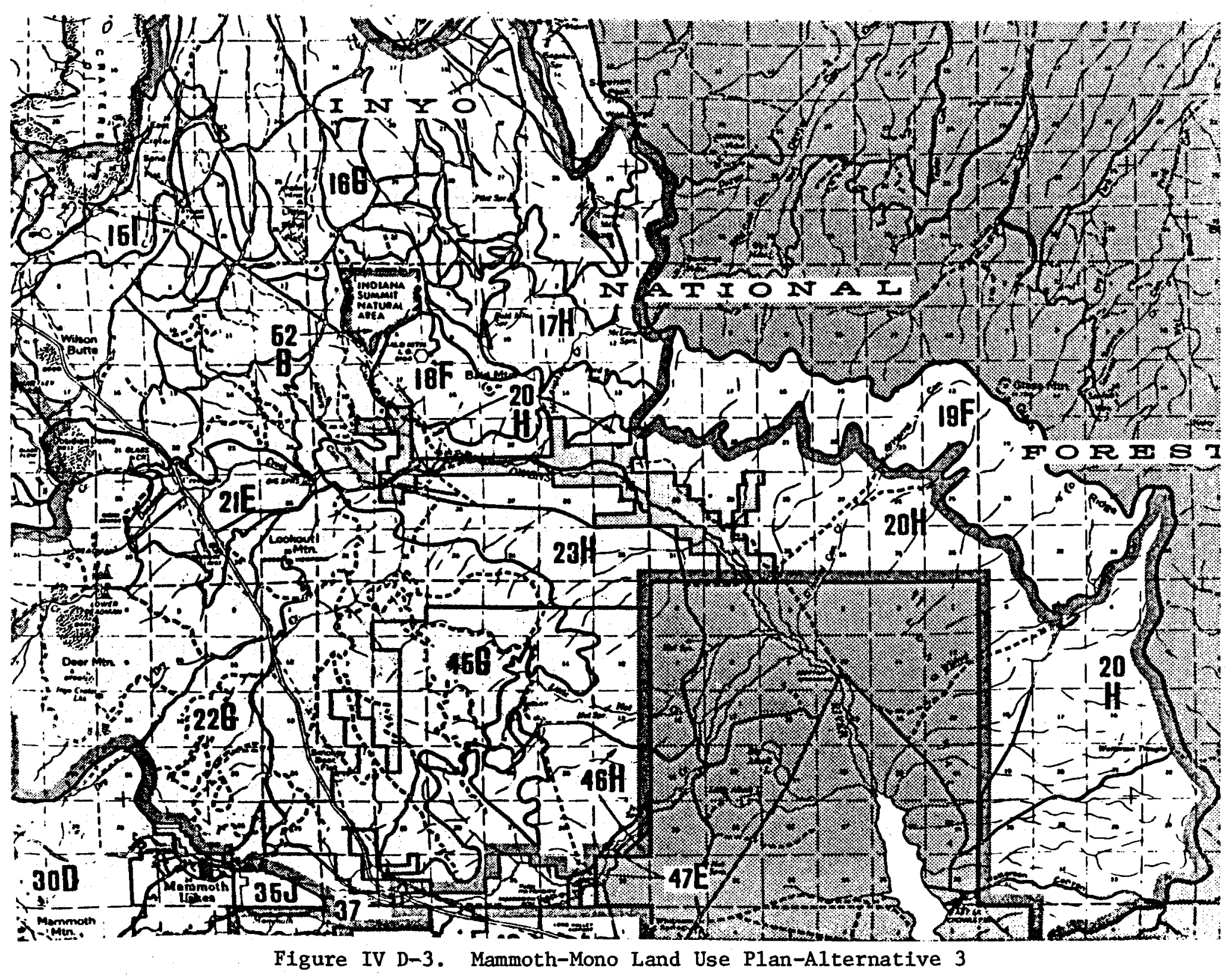




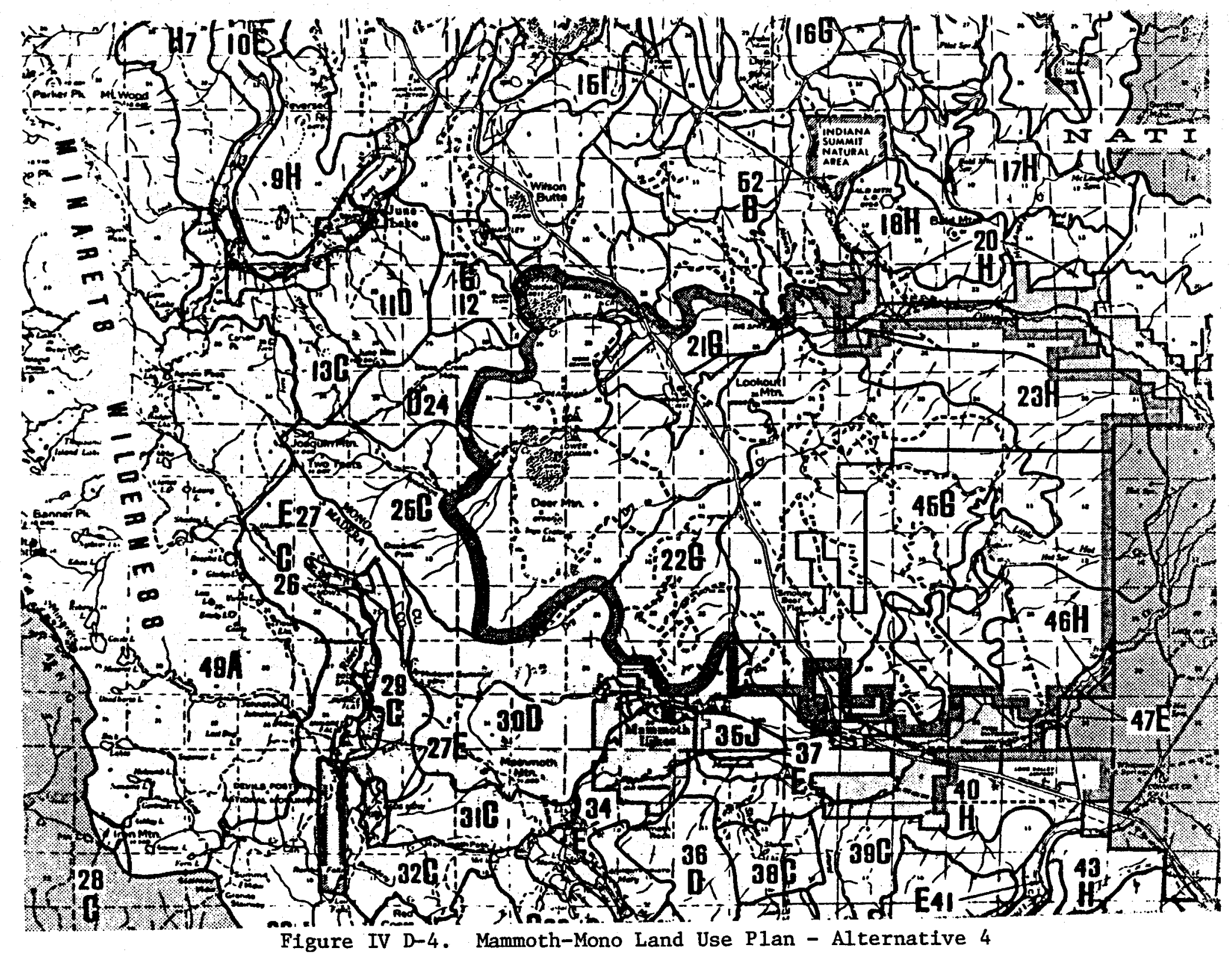


A1t 5. Geothermal development limited to "grandfather lands". NSO leasing near Hot Creek.

Potential geothermal area 16,730 a (figure IV D-5)

Alt.6. Extends geothermal development slightly northward and westward of "grandfather lands". NSO leasing of Hot Creek area. Recommended development area is that being studied in current geothermal EAR.

Potential geothermal area 26,330 a (figure IV D-6)

(2) Forest Service Evaluation of Alternatives. Appendix D-2 reproduces the evaluation summary tables from the Land Use P1an. In examining them it is most important to remember that the FS evaluates the six alternatives against each other not against meeting some other goal (such as national energy needs). Also, the six alternatives are based on overall balanced land use plans (from the FS viewpoint); there is not a specific "Geothermal Plan" that addresses how maximum geothermal development (in minimal time) can occur with consideration of minimizing its impact on environmental, socio-economic, and archaeological concerns.

The summary evaluation used by the FS to identify the preferred alternative is shown in Appendix D-2. The preferred alternative (Alternative 6) targets a 10,000-acre extension of the grandfather lands for gethermal leasing for a total of 26,330 acres.

(3) Implications of the Recommended Alternative on Geothermal Development. Alternative 6 does target development on the currently most interesting and promising lands; it will fit the needs for a start on initial exploration and development. Since no other land in the Planning Unit is allocated for geothermal exploration or leasing (even on a minimal disturbance basis), it will not be possible to fully explore or define the extend of a possible resource in other parts of the KGRA. To modify the Land Use Plan at a later date for this purpose will be costly and time-consuming. It might have been possible to at least allow for some form of exploration (and possible development) in other areas of the Planning Unit with the future preparation of geothermal specific environmental documents.

b. The Current (In Preparation) Geotherma1 EAR. An EAR for the 26,330 acres In the recommended alternative 6 is in preparation scheduled for completion in late 1978. It will delineate the specific areas unacceptable for development and the requirements, and stipulations on other areas. It is expected that locations such as view areas near highways, the recreational areas near Hot Creek, the Hot Creek Fish Hatchery area, and high-potential archaeological areas (Little Hot Creek) will not be leased or will be leased with a NSO stipulation. 


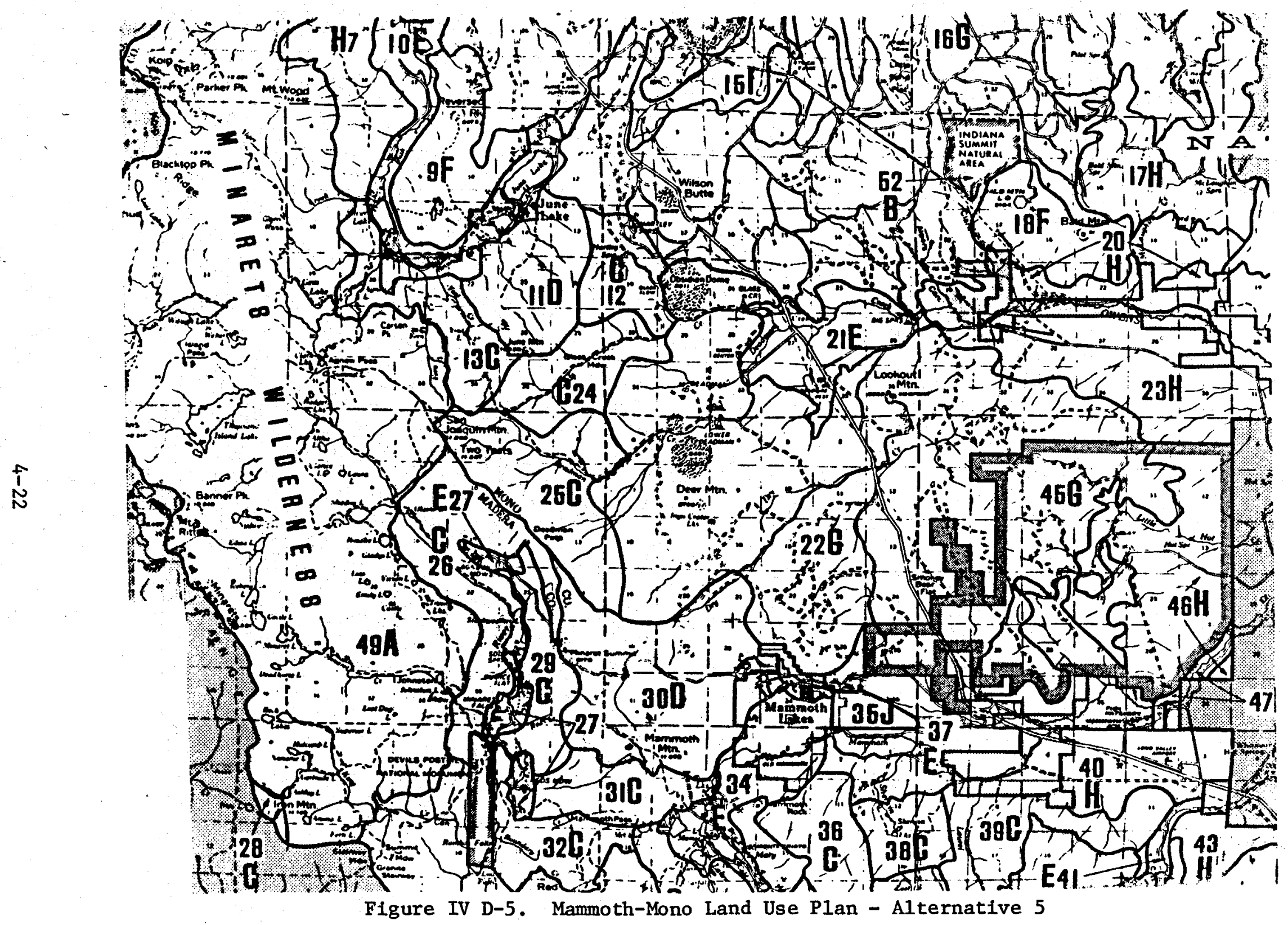


c. Development Activities. There has been drilling activity on private leases in the Casa Diablo area with moderate success. A pilot demonstration of space heating and snow removal in underway at the lumber company adjacent to Casa Dlablo; the use of geothermal for space heating (and possibly snow remova1) in the community of Mammoth Lakes is being proposed.

Republic has drilled a well on its BLM lease (figure IV D-2); it turned out essentially dry.

Union is postponing drilling on its private lease in the "clay pit" (figure IV D-2) pending leasing definition. They fear that drilling results could affect leasing costs.

\section{E. COSO HOT SPRINGS}

1. Summary

The Coso Hot Springs KGRA and adjacent area has been estimated by the USGS to be particularly promising, although currently unproven. First lease applications were made in January 1974. In a11, 58 noncompetitive lease applications have been made; none let. Thirty-four have been closed out because of withdrawals or rejections of the applications. of the remaining 24 still pending, all but six are inside the KGRA, which was expanded in August of 1976 and again in April of 1978. About twothirds of the lands, and the lands of greatest indicated-potential, are Navy withdrawn lands associated with the Naval Weapons Center at China Lake. Late in 1977 the BLM and the Navy drafted a memo of understanding, which establishes a plan under which 80,000 acres of BLM and Navy lands will be evaluated for leasing. This study area was established based on heat flow data. The BLM is in the process of contracting for the Environmental statement (ES) on these acres. According to the joint plan, leasing is scheduled in January of 1981. The BLM Office in Bakersfield feels that the ES and leasing program at Coso are moving well now.

The primary concerns to be addressed in developing leasing plans are preserving the Navy mission at the Weapons Center and protecting those areas of high archeology value and religious significance to the Native Americans of the Owens Valley. It is doubtful that the lands associated with Coso Hot Springs itself will be leased. In addition, there also appear to be 5000 acres in the northwest portion of the study area, which potentially could be classified as "roadless".

Because of the limited knowledge of the resources in the area and the unknowns associated with the impact of potential geothermal development, the Navy would prefer to see a phased leasing program, in which succeeding development steps could be evaluated before further approvals are granted.

The Navy is formulating plans which could lead to Navy owned power plants on their acquired fee lands in the KGRA. 


\section{Area Description}

Figure IV E-1 shows the current boundaries of the KGRA. It consists of approximately 106,000 acres. Roughly two-thirds is Navy withdrawn lands. The areas of highest indicated geothermal potential are on lands withdrawn by the Navy and on public lands acquired by the Navy. The area within the greater-than -3.5 heat flow units, in Figure IV E-1, is estimated to be the most promising.

The original Coso Hot Springs KGRA was established in March 1971, based on data gathered from geologic investigation conducted by the U.S. Navy and the California Division of Mines and Geology. It comprised 51,760 acres. The KGRA has been expanded on two subsequent occasions. In August 1976, 5000 acres were added to the KGRA, primarily as a result of overlapping non-competitive lease applications by the Getty Oil Company and Union Oil (CA 1022 and CA 1041). In April of 1978 an additional 50,000 acres were added as a result of more extensive heat flow data that indicated the potential resource extended further to the north and east than the original KGRA boundaries.

At Coso Hot Springs there are fumaroles, boiling springs, mercury deposits and shallow wells with temperatures up to 2080F. There are several holocene perlite domes and basalt flows in the nearby area. In 1967 the U.S. Navy and the California Division of Mines and Geology drilled a shallow well, 375 feet deep, which produced steam and water at $2870 \mathrm{~F}$. In 1977 , under a DOE supported effort, the Navy drilled a we11 to a depth of 4800 feet. Temperatures were around $390^{\circ} \mathrm{F}$. The well was flow tested for $1-1 / 2$ hours and produced steam at a rate of 70,000 pounds per hour before it was closed off. The Navy has obtained the necessary permits to conduct more extensive well flow tests, including a review by the National Advisory Council on Historic Preservation on the effect of the proposed test program on the hot springs.* The test.s were initiated the first part of September 1978.

\section{Leasing Background}

Fifty-eight noncompetitive lease applications have been made on the lands in the Coso KGRA area. The earliest dates back to January 1974. No leases have been let. of the 58 filed, 34 have been closed out; 11 being withdrawn, 2 being rejected because of KGRA determination by the USGS; and 21, primarily on Navy withdrawn lands, being rejected because the land was not avallable for leasing. The rejections occurred in 1976, most of them within two to eight months of receiving the applications. The two that were rejected because of KGRA determination were resolved after 28 months. Table IV E-1 lists the 24 lease applications which were still pending as of May of this year. of the 24, only six include lands outside the revised KGRA (CA1018, CA4690, CA4806, CA1031, CA1042, CA1046). There is a two section overlap between

\footnotetext{
*Navy data indicate the potential impact would not be measurable.
} 


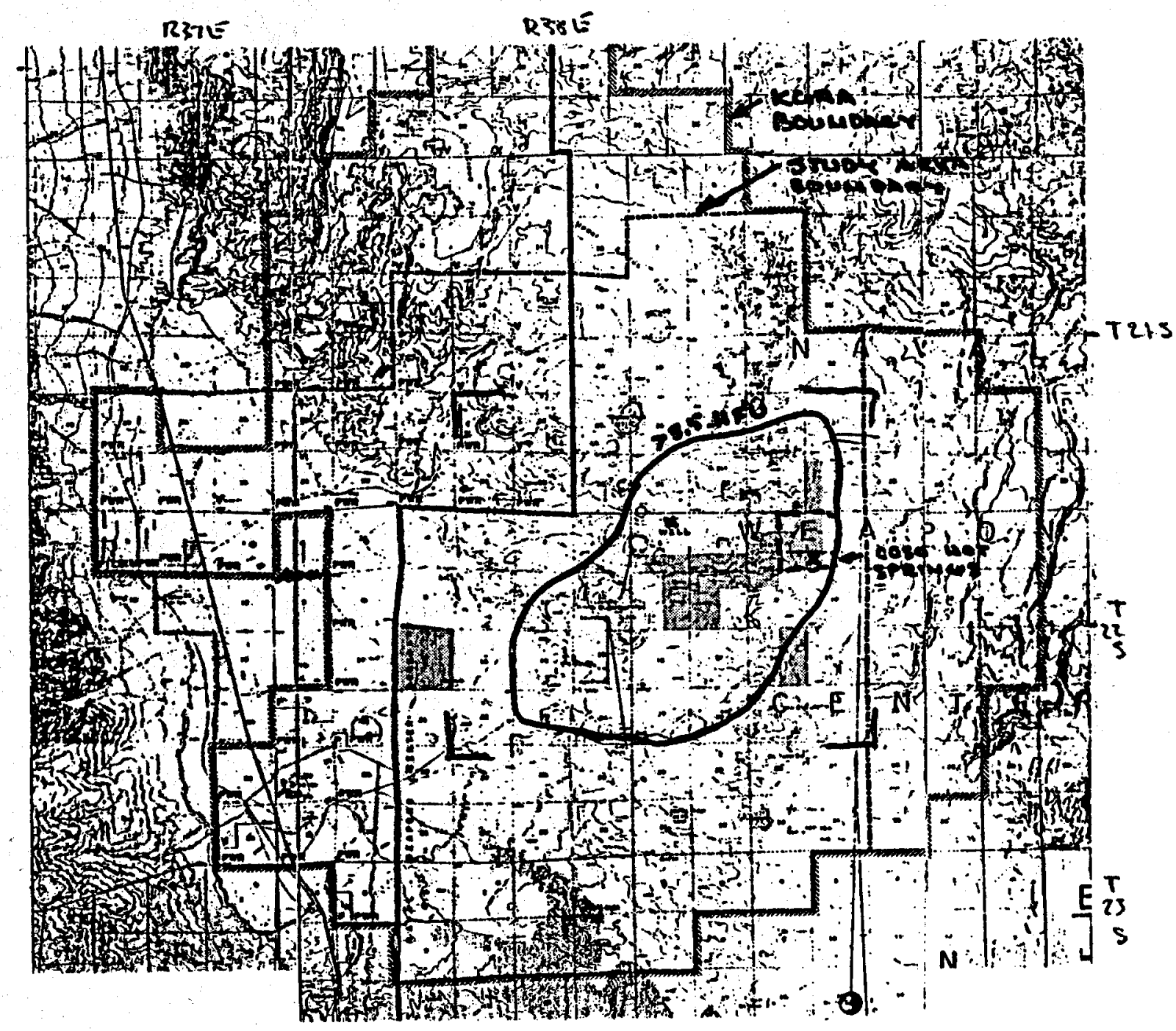

Figure IV E-1. Coso Hot Springs KGRA and Study Area 
Table IV E-1. Coso: Noncompetitive Lease Applications

\begin{tabular}{|c|c|c|c|c|c|c|c|c|}
\hline $\begin{array}{c}\text { Lease } \\
\text { Application }\end{array}$ & Applicant & Acreage & $\underset{\text { Date }}{\text { Application }}$ & $\begin{array}{c}\text { To } \\
\text { District } \\
\text { Office }\end{array}$ & $\begin{array}{c}\text { Application } \\
\text { Withdrawn }\end{array}$ & $\begin{array}{c}\text { NC Lease } \\
\text { Issued }\end{array}$ & $\begin{array}{l}\text { Lease } \\
\text { Refected }\end{array}$ & Comments \\
\hline$\frac{\mathrm{CA} 1018}{\mathrm{CA} 2250}$ & $\begin{array}{l}\text { Mono Power Co. } \\
\text { Mono Power co. }\end{array}$ & $\begin{array}{l}2479 \\
1280\end{array}$ & $\begin{array}{l}1-31-74 \\
7-03-74\end{array}$ & $\begin{array}{l}10-13-76 \\
10-13-76\end{array}$ & & * & .. & $\begin{array}{l}\text { - } 3 \text { sections outside KGRA (BLM); } 3 \text { sections Inside } \\
\text { revised KGRA (BLM) } \\
\text { - Duplicates } 2 \text { sections of CA } 1018 \text { in revined KGRA } \\
\text { (BLM) }\end{array}$ \\
\hline CA $2590^{\circ}$ & Getty 011 Co. & 1280 & $12-30-74$ & $10-13-76$ & & * & & - 2 sections in revised KGRA (BLM) \\
\hline $\begin{array}{l}\text { CA } 4688 \\
\text { CA } 4689 \\
\text { CA } 4690 \\
\text { CA } 4691 \\
\text { CA } 4692 \\
\text { CA } 4804 \\
\text { CA } 4805 \\
\text { CA } 4806 \\
\end{array}$ & $\begin{array}{l}\text { Sulphur River } \\
\text { Exploration Co. } \\
\text { Sulphur River } \\
\text { Exploration Co. } \\
\text { Sulphur River } \\
\text { Exploration Co. } \\
\text { Sulphur River } \\
\text { Exploration Co. } \\
\text { Sulphur River } \\
\text { Exploration Co. } \\
\text { Sulphur River } \\
\text { Exploration Co. } \\
\text { Sulphur River } \\
\text { Exploration Co. } \\
\text { Sulphur RIver } \\
\text { Exploration Co. }\end{array}$ & $\begin{array}{l}2567 \\
2560 \\
2560 \\
2562\end{array}$ & $\begin{array}{l}10-31-77 \\
10-31-77 \\
10-31-77 \\
10-31-77 \\
10-31-77 \\
12-08-77 \\
12-08-77 \\
12-08-77\end{array}$ & $4-05-78$ & & $\begin{array}{l}* \\
* \\
* \\
* \\
* \\
* \\
* \\
*\end{array}$ & $\begin{array}{l}4-14-78(1) \\
4-14-78(1) \\
4-14-78(1) \\
4-14-78(1) \\
4-14-78(1)\end{array} \mid$ & $\begin{array}{l}\text { - } 4 \text { sections in revised KGRA (Navy); } \\
\text { - } 4 \text { sections in revised KGRA (Navy) } \\
\text { - } 4 \text { sections outside KGRA (Navy) } \\
\text { - } 4 \text { sections in revised KGRA (Navy) } \\
\text { - } 1 \text { section in revised KGRA (Navy); } 3 \text { sections } \\
\text { outside KGRA (Navy) } \\
\text { - } 4 \text { sections 1n revised KGRA (Navy) } \\
\text { - } 3 \text { sections in revised KGRA (Navy) } \\
\text { - } 1 \text { section in revised KGRA (BLM); } 3 \text { sections } \\
\text { outside KGRA (BLM) }\end{array}$ \\
\hline $\begin{array}{l}\text { CA } 4682 \\
\text { CA } 4683 \\
\text { CA } 4684 \\
\text { CA } 4685 \\
\text { CA } 4686 \\
\text { CA } 4760 \\
\text { CA } 5018\end{array}$ & $\begin{array}{l}\text { Supron Energy Corp. } \\
\text { Supron Energy Corp } \\
\text { Supron Energy Corp } \\
\text { Supron Energy Corp } \\
\text { Supron Energy Corp } \\
\text { Supron Energy Corp } \\
\text { Supron Energy Corp } \\
\text { Supron Energy Corp }\end{array}$ & $\begin{array}{r}2200 \\
2560 \\
2554 \\
2240 \\
2560 \\
1920 \\
1119 \\
640\end{array}$ & $\begin{array}{r}10-31-77 \\
10-31-77 \\
10-31-77 \\
10-31-77 \\
10-31-77 \\
10-31-77 \\
11-30-77 \\
4-03-78\end{array}$ & & & $\begin{array}{l}* \\
\star \\
* \\
* \\
* \\
* \\
*\end{array}$ & $\mid \begin{array}{cc}5-10-77 \\
1 & \text { section } \\
& (8) \\
& \\
& \\
& \\
& \end{array}$ & $\begin{array}{l}\text { - } 4 \text { sections in revised KGRA (BLM) } \\
\text { - } 4 \text { sections in revised KGRA (Navy) } \\
4 \text { sections in revised KGRA (Navy) } \\
\text { 4 sections in revised KGRA (Navy) } \\
\text { - } 4 \text { sections in revised KGRA (Navy) } \\
\text { - } 2 \text { sections in revised KGRA (Navy) } \\
\text { - Reapplicatication on revised KGRA (BLM) } \\
\end{array}$ \\
\hline $\begin{array}{ll}\mathrm{CA} & 1031 \\
\mathrm{CA} & \\
\mathrm{CA} & 1042 \\
\end{array}$ & $\begin{array}{l}\text { Unton ofl co. } \\
\text { Unton oil co. } \\
\text { Unton oil co. } \\
\text { Union oli co. }\end{array}$ & $\begin{array}{l}2240 \\
1119\end{array}$ & $\begin{array}{l}1-31-74 \\
1-31-74 \\
1-31-74 \\
11-21-77\end{array}$ & $\begin{array}{l}10-13-76 \\
10-13-76 \\
10-13-76\end{array} \mid$ & 2 sect only & * & $\mid \begin{array}{l}11-12-74 \\
5 \text { sects } \\
1 \text { section } \\
8\end{array}$ & $\begin{array}{l}\text { - Remaining } 2 \text { section: } 1 \text { outside KGRA (BLM) and } \\
\text { 1 section in revised KGRA (BLM) } \\
\text { Of } 5 \text { rejection sections: 1 was patent lands and } \\
4 \text { in revised KGRA (BLM). Remaining section } \\
\text { outside KGRA (BLM) } \\
\text { - } 3 \text { remaining sections outside KGRA (BLM) } \\
\text { - } 2 \text { sections in revised KGRA (BLM) Reapplication } \\
\text { on } 2 \text { sections rejected 1n CA 1031 }\end{array}$ \\
\hline R 4344 & Crowhite Corp & 770 & $6-21-71$ & & & * & & $\begin{array}{l}\text { - Mining claims on } 6 \text { sections: all within original } \\
\text { KGRA - } 2 \text { on Navy, } 4 \text { BLM }\end{array}$ \\
\hline
\end{tabular}

- Lease not signed (action pending)

(1) Rejected as lands not avallable for lease (Navy withdrawn under PL0431). Rejection being appealed to IBLA

(1) Rejected as lands not avallable for lease (Navy withdrawn under
(8) Fallure to apply for all available lands (43 CFR 3210.2-1C). 
CA1018 and CA1046. The BLM plans to process their open noncompetitive lease applications after completing the Coso EIS in January 1981. The plans for those applications on Navy lands outside the KGRA are uncertain.

Much of the apparent delay in the leasing program at Coso was the result of the lack of agreement between the Navy and the BLM on the potential leasing of the Navy withdrawn lands for geothermal development. The BLM did have tentative plans for leasing the lands to the west of the Navy withdrawn lands, but such an action begged the issue that the more promising resource potential and the area of greater industry interest was associated with the Navy withdrawn lands. The Navy, in turn, was very concerned that geothermal leasing on their lands would interfere with their mission at the Naval Weapons center which is to continue as the principal Navy RDT\&E center for air warfare and missile weapon systems.

The 'station was established in November 1943 under PLO-431 to meet the immediate needs of war-time rocket developments and as a center for permanent weapon research and development for the Navy. The major advantage of the isolated location was that it made it possible to do the testing of new experimental weapons on ranges close to the supporting research laboratories. The Navy-owned home town at China Lake and the adjacent development at Ridgerest support a population in excess of 20,000 people. As a result the Weapon Center provides a unique facility to the Navy which would be difficult to duplicate.

A series of meetings between the BLM and the Navy resulted in the drafting of a memo of understanding between the two agencies which could result in substantial geothermal leasing and development beginning in 1981 compatible with the Navy mission. The Navy stipulations associated with the memo of understanding are in Appendix E-1.

\section{Activities}

a. Leasing Development Plan. The BLM is in the process of letting a major contract for the preparation of a comprehensive Environmental Statement (ES) prior to initiating the proposed action calling for the leasing of 1and within the Coso Geothermal Study Area (CGSA). The study area includes 80,640 acres. Of this total, 30,080 are on public lands (BLM), 47,640 acres are Navy withdrawn and approximately 2,999 acres are Navy acquired lands. The boundaries of the study area, shown in Figure IV E-1, include the area with indicated heat flow greater than 2.5 heat flow units, and the noncompetitive lease applications. The schedules for the ES preparation and tentative leasing are shown in Appendix E-2.

As is indicated in the ES Contract Preparation Plan (Appendix E-3), the ES wi11, be based on a quantitative geothermal development model of probably 2560 acres which will provide predictable and quantifiable impact assumptions when applied to the study area. The model will be based upon the anticipated geothermal potential of the CGSA and will quantify acres disturbed by each activity within each stage of development; roads, pipelines, drill pads, number of wells needed to power a 
plant, number of people employed within each stage, etc. The model will be multiplied to cover the CGSA. The resources within the CGSA will be inventoried and assessed to indicate various sensitivities and unique qualities. The development model will be applied to the sensitivity classifications, and impacts will be deduced, indicating areas where resource conflicts/impacts are of high, medium and low significance. In discussions with BLM and Navy personnel the major concerns are:

- impacts on cultural archeology

- air quality deterioration which could jeopardize the Navy mission*

- preservation of the Coso Hot Springs because of their sacred and religious significance to the Native Americans of the Owens Valley.

It is doubtful that development will be allowed close to the Hot Springs or in other areas of high cultural value. There also appear to be roadless areas of over 5,000 acres within the northwest portion of this study area which will complicate mitigation measures.

The Coso ES Project Manager, Janis Bowles, indicated that this is the first ES done on contract out of their offices and was necessary because the BLM staff was swamped by roadless area and grazing land studies. She also indicated that once the decision was made to contract and the money provided, things really moved well.

b. Other Development Activities. The Navy is interested in developing their acquired (fee) lands to provide a source of reliable, cost-stable power for the Weapon Center with the possibility of wheeling excess power to other military bases in the state. By providing such a source of guaranteed, low-cost power the Navy feels that they can increase the value of the $R \& D$ dollar at the base and can assist in maintaining marginal bases which could be closed by escalating energy costs. The Navy is thinking of a $25 \mathrm{MW}$ power plant initially and is planning to contract for such a development next year. Sixteen to seventeen firms have expressed interest. The Navy development program will consist of five controlled phases:

- field investigation and research
- field exploration
- field development
- plant siting
- plant construction

*Primarily concerned with the effects of sulfates on the visable spectrum. 
The Navy feels that data forthcoming on their fee lands development will serve as a pathfinder on the lands to be leased by the BLM. The Navy is seeking authorization from Congress on their development program.

In addition to the Navy activities the DOE is sponsoring an Environmental Overview Program, managed by Lawrence Livermore Laboratories, at Coso. This is a longer term program, aimed at developing more detailed environmental data and impact assessment than will be possible under the BLM ES activities and hence will provide more detailed data on potential development options. The Navy feels that the overview activities should accelerate post lease development decisions.

F. IMPERIAL VALLEY

1. Summary

Geothermal development in Imperial county is active reflecting the results of a county interested in development supported by a Federal/ State cooperative effort.

Most land in the region is state or private; there is Bureau of Reclamation land in the Dunes, Glamis and East Mesa, and BLM land in the North Salton Sea area. The county, state, BLM and USGS have cooperated on joint Environmental documents. Exploration and development is active; 10MW power plants are underway in East Mesa (Magma and Republic). SDG\&E plans a plant at East Mesa. SCE plans a plant at Salton Sea.

The development problems that remain are mostly technical; salinity, temperature, reinjection, subsidance, etc. The availability of cooling water and transmission lines are also of concern.

\section{Discussion}

The region is a sedimentary basis under heavy irrigated agricultural use. The county is an active and interested force in geothermal development. A geothermal component to the county land use plan has been developed and state, local and federal agencies have cooperated in writing joint environmental documents satisfying both NEPA and CEQA. The advanced state of development reflects the probable quality of the resource and the results of joint cooperative efforts between government agencies and industry.

Recently, non-competitive NSo leases have been let by the BLM in the North Salton area permitting exploration activities on nearby state leased land.

Development problems that remain are mostly technical or involve cooling water requirements and transmission lines. The resource seems to range from hot and highly saline in the north to cooler and less saline in the south. Problems in economically and rellability utilizing a highly saline resource and a cooler resource are under study. Required reinjection to avoid land subsidance may also present a problem, particularly with highly saline water. 
Construction of $10 \mathrm{MW}$ power plants by Magma and Republic at East Mesa is underway. SDG\&E plans a $50 \mathrm{MW}$ plant at East Mesa (with Republic and Ralph M. Parsons). SCE plans a $45 \mathrm{MW}$ plant at Heber (with Chevron) and is working with Union 0il on a $10 \mathrm{MW}$ pilot plant at Brawley (by Rogers Engineering).

G. THE GEYERS

1. Summary

Continued rapid development of the hot dry steam resource depends to a large extent on solving air quality problems $\left(\mathrm{H}_{2} \mathrm{~S}\right)$.

The BLM is close to the start of competitive leasing of 5 tracts (3600 A) of mineral reserve land in or adjacent to the current field boundary (Figure IV G-1).

Northern California Power Association (NCPA) is proceeding with a $100 \mathrm{MW}$ plant to be built on a Shell Federal Lease. Siting approval is being processed through California Energy Commission procedures (although on federal land) in a cooperative between the BLM and the Commission.

Leasing of other land in surrounding areas (and KGRA's) awaits completion of environment documentation by either the ELM or USFS.

Development of a possible hot water resource is not active; it may await full development of steam usage.

\section{Leasing Background}

To date 14 competitive leases have been let totaling about 12,000 acres. Of these 12 were let in the last half of 1974 and two were let in late 1977. There have been NC applications for 208 leases; all have been withdrawn or rejected.

\section{Discussion}

The Geysers steam field is currently producing 502 . MW of power and the State of California and industry are interested in swift expansion. New power development depends greatly on overcoming the $\mathrm{H}_{2} \mathrm{~S}$ problem involving interrelationships between the various county's in the area. As development extends toward recreational areas and toward Lake County, air quality and other environmental concerns become more complicated.

In an effort to establish a cooperative effort with the State of California and (hopefully) to best satisfy local concerns, the BLM is siting a $100 \mathrm{MW}$ NCPA power plant in a Shel1 Federal lease through the California Energy Commission and its procedures. 


\section{Leceners}

- - - - Curnour Fierdo Boundandr

1100000000 en Estimatrs Protisos

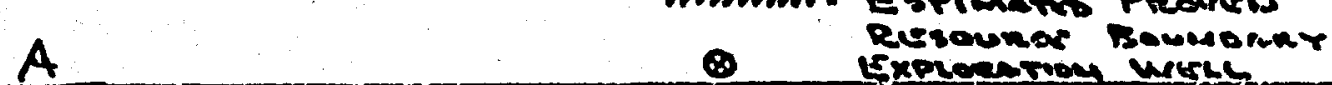

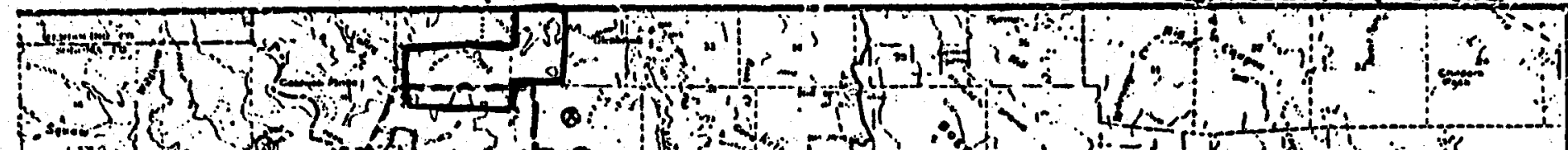

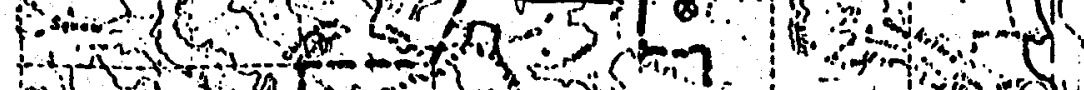

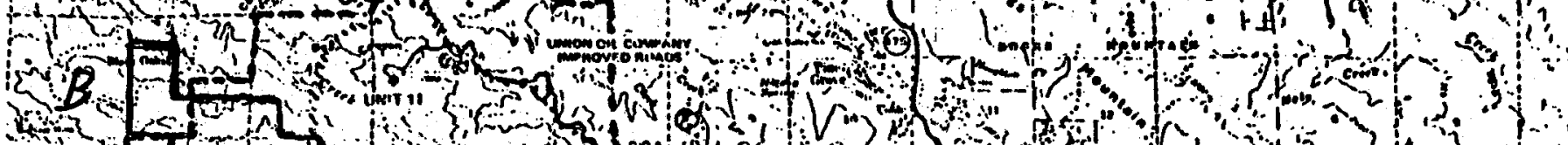
De

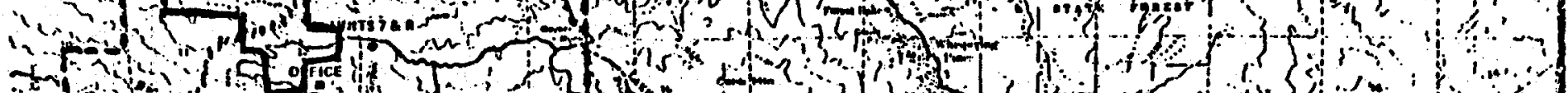

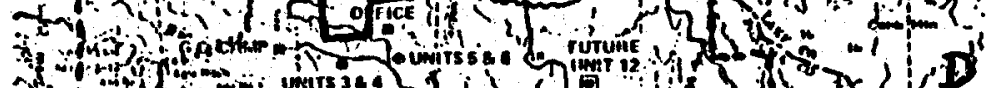
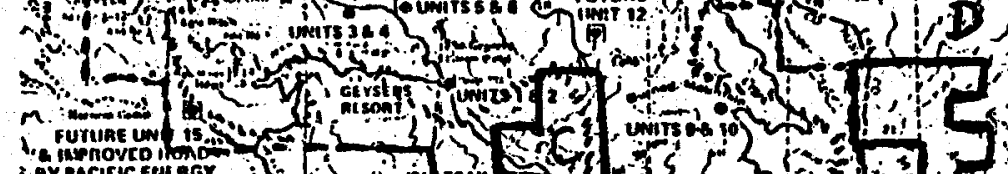

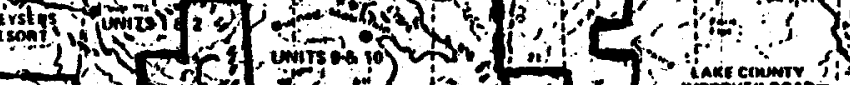

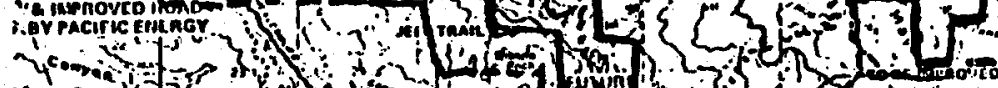

M
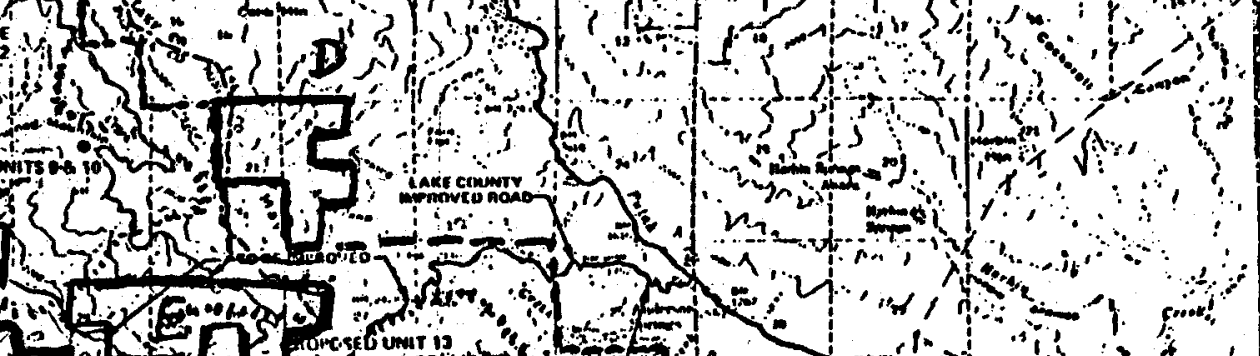

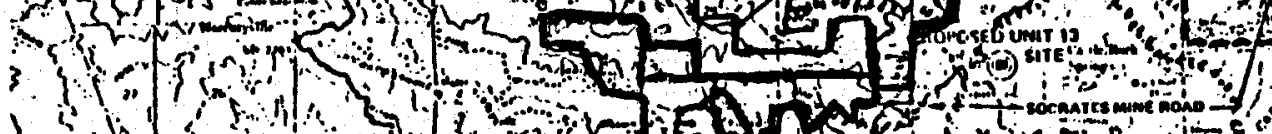

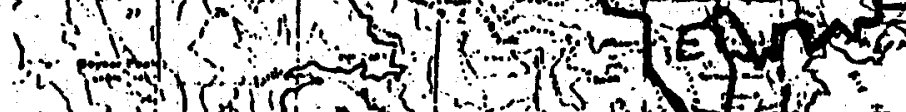

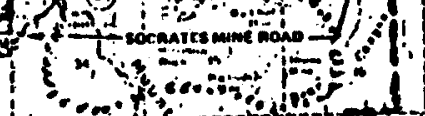

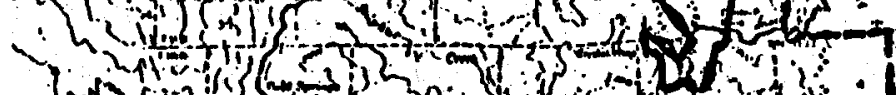

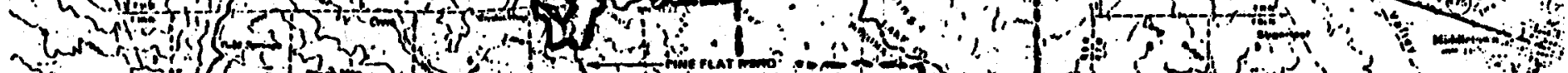

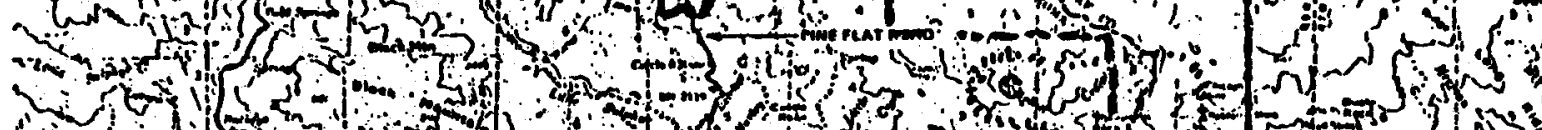

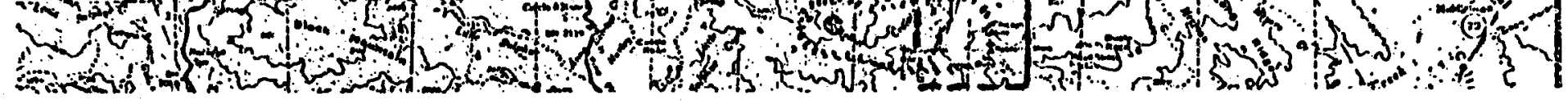

Figure IV G-1. BLM Mineral Reserve Lands to be Leased 
The BLM has issued a draft EAR on 5 tracts consisting of 3600 acres adjacent to or within the existing steam field (Figure IV G-1). Competitive leasing is expected shortly after final approval. The NCPA experience should establish procedures for development on these lands. 



\section{$A-1$}

\section{BACKGROUND}

- In May of 1974, the Bureau of Land Management informed the Targhee' Forest that applications for geothermal leases for the Island Park area had bees recelved.

- By mid-1975 more than 150 lease applications had been received.

- The Geothermal Steam Act of 1970 (84 stat. 1566-1574; 30. U.S.C. 1001-1025) provides that lands withdrawn or acquired in aid of functions of the Department of Agriculture can only be leased with the consent of and under such terms and conditions as may be prescribed by the head of that department.

- On May 7, 1975, personnel. from U.S. Geological Survey; Bureau of Land Management, Forest Service, U.S. Fish and Wildlife Service and National Park Service met in Boise io discuss the Island Park Geothermal Area. the Targhee N.F. would serve as the lead for the interagency effort. They agreed upon a target date of 1978 for the draft statement.

- In Juiy 1975, the state Director, B.I.M., Idaho state office, notified. all lease applicants that an environmental statement would precede any geothermal leases (Appendix).

- Considerable controversy developed after the decision was made to go with" a full environmental statement. This resulted in at least two congressional inquiries. Responses to these inquiries comitted the Forest service to timetable pending funding and personnel (Appendix).

- On October 17, 1975, Targhee Supervisor George Olson Issued a statement to the Subcomittee on Energy Research and Water Resources of the Senste Interior Comittee (Appendix). 


\section{$A-2$}

\section{SCHEDULE}

Complete Data Gathering

$12 / 1 / 77$

Organizational Review

Present inventories, discuss involvement document

$12 / 6-9 / 77$

Complete Involvement Document

$1 / 1 / 78$

Conduct Public Involvement Session

$2 / 4 / 78$

Analyze Public Input

$2 / 15 / 78$

Complete Draft Statement

$4 / 10 / 78$

Draft Review

Study team

$4 / 24 / 78$

Others

Draft Statement Printing

$6 / 1 / 78$

$6 / 30 / 78$

Send to Interested Publics

$7 / 5 / 78$

File with CEQ

$7 / 5 / 78$

Organizational Meeting

Review public input and reeds for additional

data and/or modification

Complete Final statcment

$10 / 20 / 78$

Final Reviews (in-service-othex appropriate agencies)

Final Printing

12/1/78

$1 / 1 / 79$

File with CEQ and Mail to Interested Publics

$1 / 5 / 79$

Implement Statement Recommendations

$4 / 5 / 79$ 
Geothermal Interagency Team

A-3

Edmund Bucknall (Ted)

Resource Management Specialist

Yellowstone National Park, Wyoming 82190

Bob Kent

Chief, Environmental Section

Office of the Area Geothermal Supervisor

. 2465 E. Bayshore Rd.

Palo Alto, CA. 94303

Forest Supervisor

ATTN: Phil Cowan

Gallatin National Forest

Box 130

Bozeman, MT. 59715

Rich Howard

Wildlife Biologist

U.S. Fish \& Wildilfe Service

Ecological Services

4620 Overland Road

Bolse, Idaho 83705

Doug Causey.

Idaho Falls District

Bureau of Land Management

940 Lincoln Road

Idaho Falls, ID. 83401

Robert E. Lewis

U.S. Geological Survey

Water Resources Div.

Box 036, FBUSCH

550 W.- Fort Street

Bolse, ID. 83724 
Fifty six people participated in the Geothermal Workshop held at Madison Junior High School, Rexburg, Idaho on Saturday, March 18, 1978.

A varlety of occupational backgrounds were represented. The following table describes the number of individuals by occupational background:

Occupational Background

Geology-Hydrology

Engineering

Wildlife

Resource Management

Agriculture

Seothermal Development

Public Utilities

Planning

Environmental Specialists

Forestry

Physics

Law

Botany

Student

Receptionist

Transportation

Economics

Other (unknown)

\section{Individuals}

12
7
7
6
3
3
2
2
2
1
1
1
1
1
1
1
1
4

Individual concerns expressed Included the following:

a. More information about the geothermal resource is needed. This was expressed by $57 \%$ of the individuals who commented.

b. Non-electric use of a geothermal resource should be considered.

c. Worst case analysis for economic considerations is unrealistic. $36 \%$ of the individual responses said more varied analysis is needed.

d. Protection of endangered or threatened wildlife species habitat is Important.

e. More alr quality data is needed.

f. The "Geysers" geothermal area should not be used as a model for Island Park geothermal development considerations. 


\section{$A-4$}

\section{Group Response}

Seven groups participated in the afternoon session. Each group had from 5 to 7 individuals. The groups were asked to collectively produce a map showing where, and where not, geothermal leasing should occur within the Island Park area. Group comments were requested to be included on the finished product.

All but one group responded by either producing a map or making - comments. Two of the groups made comments and 5 groups produced a map.

The following inferences are made from the five group maps:

a. The groups believed that the southeast corner of the Island Park area (adjacent to Yellowstone N.P.) is the most sensitive. All five groups recommended excluding leasing from some, or all, of this portion.

b. Most of the center portion of the Island Park area (Moose

- Creek Plateau) should be made available for leasing.

c. Grizzly bear habitat should be protected.

d. Protect Henry's Fork of the Snake River. Three groups identified a strip at least one mile on each side of the river that they believed should be excluded from leasing.

e. Lease those areas where visual qualities are low (low visibility).

f. Leasing should occur in the area adjacent to West Yellowstone, Montana. 
Each participant was asked to respond to the following questionnaire:

\section{ISLAND FARK GEOTHERMAL WOPKSHOP}

The following is a list of potential uses of natural resource lands. Please rank these uses in order of importance, assuming the lands being considered have the potential for all of these uses. For example. if you feel that range is the most important use of natural resource lands, place a one (1) in the box to the right of range. Please assign a different number to each use.

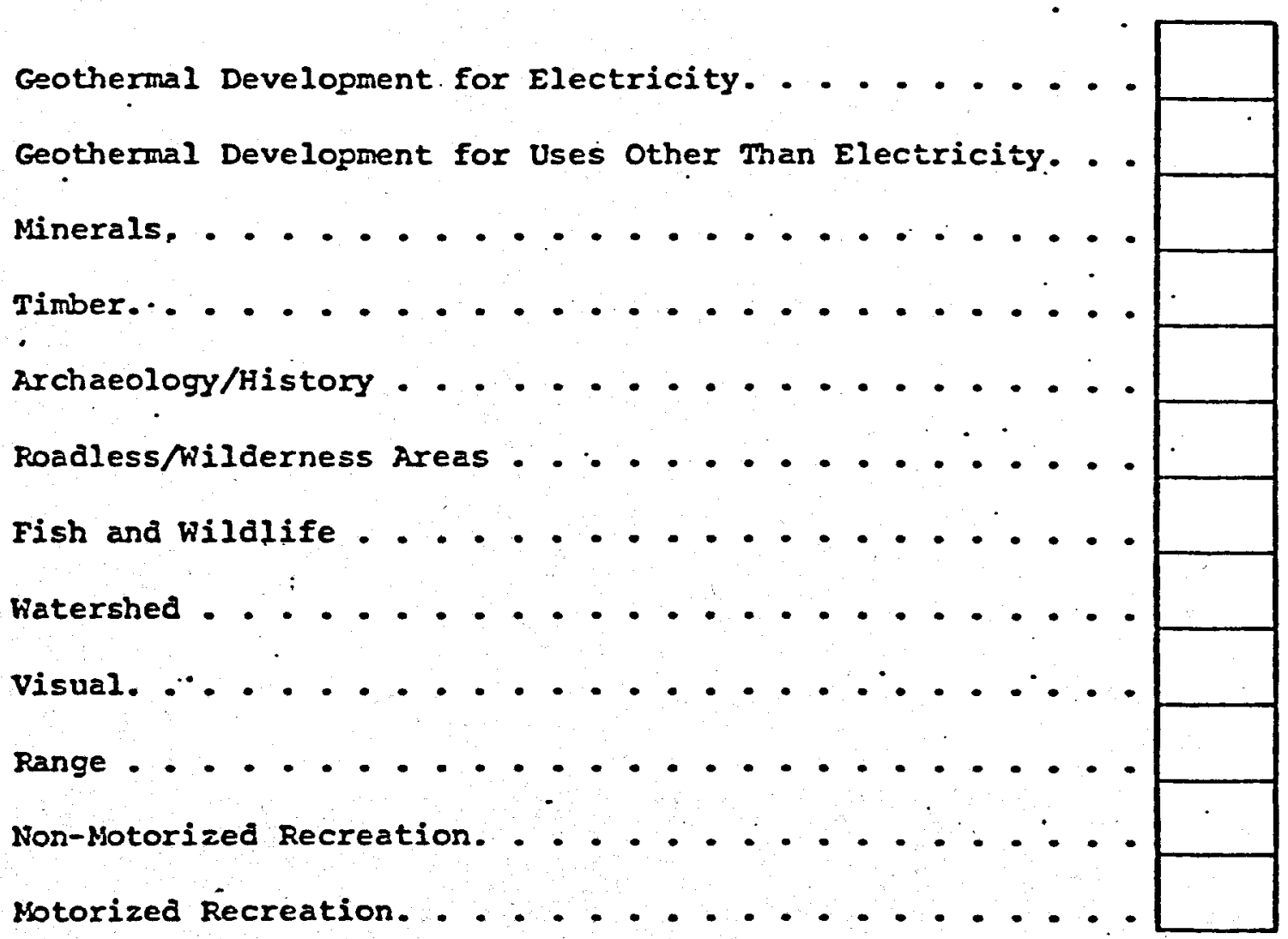

Forty-three usable questionnaires or responses were completed.

A computer program known as PUBLIC was used to analyze the forty-three questionnaires. The following discussion summarizes some of the results from PUBLIC.

The priority ranking of the potential uses most satisfactory to the majority of the forty-three respondents was as follows with use numbr one the most important and use number twelve the least important: 
Fish and WIIdIffe

Watershed

Timber

Geothermal development for electricity

Geothermal development for uses other than electricity

Range

Visual

Non-motorized Recreation

Minerals

Roadless/Wilderness Areas

Archaeology/History

Notorized Recreation
1

2

3

4

5

6

7

8

9

10

11

Twenty-five out of the forty-three respondents ranked fish and wildlife either one, two, or three. of these twenty-five, eight ranked fish and wildife with a one priority.

Twenty-three respondents ranked geothermal development for electricity with either a one, two, or three. of these twenty-three, two ranked geothermal development for electricity with a one priority.

Concern was also shown for watershed, with twenty-two respondents ranking it a one, two, or three. Of these twenty-two, eleven gave watershed a one priority.

Eleven respondents ranked range with a priority of one, two, or three, with six of these eleven respondents giving range a one priority.

Motorized recreation was given a twelve ranking by nineteen respondents.

The geothermal team has begun developing a set of alternatives for leasing ir. the Island Park area. The above summarized concerns and comments will be helpful as we proceed with alternative development and later environmental statement activities.

The time, interest and enthusiasm of those who participated in the public workshop is greatly appreciated. 


\section{A-4}

Geothermal Workshop Participants

Madison Jr. High

March 18, 1978

Mickey Beland

Geothermal Team - U.S. Forest Service

St. Anthony, Idaho 83445

(Geothermal E.S. Coordinator)

Ray Breuninger

Mt. Dept. of Natural Resources \& Cons. 32 S. Ewing,

Helena, Mt. 59601

(Geologist)

Marian Boulter

Rt. \#3, Box 290

Rexburg, Idaho 83440

(Receptionist)

Keith E. Brown

Canyon Creek, Mt. 59633

(Montana Energy office)

Ted Bucknall

P.0. Box 168

Yellowstone Park, Wyo. 82190

(Park Ranger)

Craig Carver

828 1st St. \#810

Denver, Co. 80202

(Attorney)

Douglas Causey

940 Lincoln Rd.

Idaho Falls, Idaho 83401

(Geologist - BLM)

Robert N. Chappell, DOE 550 2nd St.

Idaho Falls, Idaho 83401

(Engineer)
Eddie Chew

1546 Beverly

Idaho Falls, Idaho 83401

(Physicist)

Phil Choate

P.0. Box 351

Rexburg, Idaho 83440

(Planner)

Vernon Christoffersen

Tetonia, Idaho 83452

(Farmer)

Eugene V. Ciancanelli

- 12352 Escala Drive

San Diego, Calif. 92128

(Consulting Geologist)

Gary L. Davidson

3740 Brookfield

Idaho Falls, Idaho 83401

(Fish \& Game)

Mark Dublin

160 Pine, \#3

Idaho Falls, Idaho 83401

(Transportation Director - VISTA)

Sandy Enyeart

459 ' $I$ ' St.

Idaho Falls, Idaho 83401

(Environmental Eng. - STAFCO, INC.)

John Ferebauer

Geothermal Team - U.S. Forest Service

St. Anthony, Idaho 83445

(Economist) 
O'dell A. Frandsen

940 Lincoln Road Idaho Falls, Idaho 83401

(District Manager - BLM)

Beth Gorringe

646 E. 4 th N.

St. Anthony, Idaho 83445

Russell Hillman

P.0. Box 328

St. Anthony, Idaho 83445

(Fremont County Agent)

Roger D. Hoggan

587 Gemini

Rexburg, Idaho 83440

(Geology Prof. - Ricks)

Rich $P$. Howard

4620 Overland Rd.

Bosie, Idaho 83705

- (Biologist FWS)

Roderick A. Hutchinson

0ld Faithful

Yellowstone National Park

(Park Geologist)

David Jay

U.S. Forest Service

St. Anthony, Idaho 83445

(Fores: Supervisor)

Klem K. Kennedy

820 8th St.

Idaho Falls, Idaho 83401

(Engr.)

\section{Steven Knapp}

Box 97

Ashton, Idaho 83420

(Operations Mgr. - Fall River

Rural Electric (o-op.)

Rem Kohrt

P.0. Box 617

St. Anthony, Idaho 83445

(Forester)
Dr. John McGee

Geothermal Team - U.S. Forest Service

St. Anthony, Idaho 83445

(W1ld Iffe Biologist)

Michael McSorley

636 Pershing

Pocatello, Idaho 83201

(Env. Spec. - IDHW)

Ralph Meyer

U.S. Forest Service

West Yellowstone, Mt. 59758

(District Ranger)

William G. Miller

St. Anthony, Idaho 83445

(Idaho Geothermal Corp.)

C.F. Murer

777 Washington St.

Denver Colo. 80203

(Geologist)

Deborah Parrott

Box 91

Victor, Idaho 83455

Ralph V. Pehrson

600 So. Walnut

Boise, Idaho 83706

(Program Coordinator -

Dept. Fish \& Game)

Bruce Penske

15 Honeybee Lane

Idaho Falls, Idaho 83401

(Conservation officer)

Chris H. Peterson

673 10th St.

Idaho Falls, Idaho 83401

(Const. Engr.)

Robert Ruud

136 W. 7th S.

St. Anthony, Idaho 83445

(Idaho Geothermal Corp.) 
Fred Schmidt

112 W. Gold

Butte, Mont. 59701

(Hydro Technician)

Glan Sharp

Squirrel, Idaho 83447

Fall River Elect.

(Farmer)

Samuel E. Shepley

1453 Idaho St.

Idaho Falls, Idaho 83401

(Environmental Consultant Stafco Inc.)

P.A. Smith

Resources Co.

P.O. Box 3722

San Francisco, Ca. 94119

(Geologist/Permit Representative)

Susan G. Spencer

EG\&G, Box 1625

Idaho Falls, Idaho 83401

(Environmental Engineer)

John Sonderegger

Mont. Bureau Mines \& Geol.

Butte Mt. 59701

(Hydrogeologist)

Bob Stenner

Division of Env.

635 Pershing

Pocatello, Idaho 83201

(Env. Engr. Spec.)

Jacauelyn Sullivan

EG\&G, Idaho

P.0. Box 1625 - UPD

Idaho Falls, Idaho 83401

(Environ. Biologist/Aquatic Ecologist)
Stan Szczepanowsk1

Geothermal Team - U.S. Forest Service

St. Anthony, Idaho 83445

(Geohydrologist)

Jack Thomas

Pinehaven

Box 58

Island Park, Idaho 83429

Mrs. Jack Thomas

Pinehaven

Island Park, Idaho 83429

Ryan Tibbitts

767 W. 3rd S.

Rexburg, Idaho 83440

(Student)

Greg Tourtlotte

Chester, Idaho 83421

(Conservation officer)

Gerald Vaughan

213 Pilot Av.

Bakersfleld, Ca. 93308

(Land Representative - Occidental

Geothermal Ins.)

Jennifer Whipple.

253 Spring $S t$.

Arcata, Ca.95521

(Botanist)

Calvin H. Wickham

Box 413

Ashton, Idaho 83420

(Manager, Fall River Elec, Co-op)

Ed Williams

Ricks College

Rexburg, Idaho 83440

(Teacher - Geology) 
Robert Williams

U.S. Forest Service

St. Anthony, Idaho 83445

(Planner)

Charlie Woodward

Box 91

Victor, Idaho 83455

(Geologist)

A.D. Zierold

Id. Dept. of Lands

Statehouse,

Boise, Idaho 83720

(Resource Mgmt) 
APPENDIX B

ROOSEVELT HOT SPRINGS 


\title{
$B-1$
}

\author{
UNITED STATES DEPARTMENT OF THE INTERIOR \\ BUREAU OF LAND MANAGENENT \\ UTAH STATE OFFICE \\ Post Office Box No. 11505 \\ Salt Lake City, Utah 84111
}

Notice of Geothermal Lease Sale

\section{ROOSEVELT HOT SPRINGS KGRA}

U. S. DEPARTMENT OF THE INTERIOR, Bureau of Land Management, State Office, Salt Iake City, Utah. Notice is hereby given that twelve (12) leasing units of land, totaling 23,391.13 acres within the Roosevelt Hot Springs Known Geothermal Resource Area, in Beaver County, Utah, are offered for geothermal leasing through SEALED BIDS on the terms hereinafter specified to the responsible qualified bidders of the highest cash bonus for the privilege of leasing Units 1 to 12 inclusive, pursuant to the Geothermal Steam Act of December 24, 1970 (84 Stat. 1566; U.S.C. 1001-1025) and the regulations promulgated thereunder ( 43 CFR, Group 3200). All bids must be submitted on or before 10:00 AM, MDT, July $30 \quad 1974$, to the State Director, Bureau of Land Management, P. 0 . Box 11505, Salt Lake City, Utah 84111, if by mail; or if in person to Room 8103 . Federal Building, 125 South State Street, Salt Lake City, Utah. Bids will be opened and read at that time in Room 8103 , in accordance with 43 CFR $3220.6(a)$. Bids may not be modified or withdrawn unless the modification or withdrawal is received prior to the time fixed for opening of bids. No bids received after the hour specified herein will be considered. The Government reserves the right to reject any and all bids. Separate bids must be submitted on each lease unit, and must be accompanied by a completed Form 1140-8, Equal Opportunity Compliance Report Certification, and a completed Form 1140-7, Equal Opportunity Affirmative Action Program Representation. Each bidder must submit with each bid a certified or cashier's check, bank draft, or money order payable to the Bureau of Land Management, or cash, in the amount of one-half of the amount of bid, and proof of qualifications as required by the regulations $43 \mathrm{CFR}$, Group 3200. The envelope in which the bid is submitted must be plainly marked that it is NOT TO BE OPENED BEFORE THE DATE AND HOUR SET HEREIN; and must show the lease unit number and that it is for the Roosevelt Hot Springs known Geothermal Resource Area, The successful bldder, as a condition of award, will be required to sign a certificate to the effect that the bid was arrived at by the bidder or offeror independently, and was tendered without collusion with any other bidder or offeror (Form 1140-6, Independent Price Determination Certificate). Before issuance of a lease, the successful bidder must pay the remainder of the bonus, plus the first year's annual rental. In addition, the successful bidder must furnish an acceptable lease compliance surety bond in the sum of not less than $\$ 10,000$, together with a proposed plan of operation as required by $43 \mathrm{CFR} 3210.2-1$ (d) before issuance of a lease. In 1ieu of 3 lease compliance bond for each lease, a successful bidder may furnish a bond in the amount of not less than $\$ 150,000$ for full nationwide coverage for all of said bidder's Federal geothermal. leases, or not less than $\$ 50,000$ for coverage of all of said bidder's Federal geothermal leascs in the State of Utah. The deposits of the other bidders will be returned upon acceptance of the successful bid. Bidders are warned against violation of Title 18, U.S.C. 1860, prohibiting unlawful combination or intimidation of bidders. Any bonus bid 
considered as inadequate on the basis of the estimated value of the lease unit will be rejected. Royaltles payible to the United States will be at the rate of: (a) 10 percent of the amount or value of steam or any other form of heat or energy derfved from production; (b) 5 percent of the value of any by-product derived from production under the lease, except that as to any by-product which is a mineral named in Section 1 of the Mineral Leasing Act of February 25 , 1920, as amended ( 30 U.S.C. 181), the royalty for such mineral shall be the same as provided in that Act; (c) 5 percent of the value of commercially demineralized water sold or utilized by the lessee, except that no payment of royalty will be required on such water used in plant operations for cooling or in the generation of electric energy or otherwise. Annual rental for the first through the fifth years of the lease will be at the rate of $\$ 2$ per acre or fraction thereof; for the sixth lease year, and for each year thereafter prior to production, the rental will be the amount of the rental for the preceding year, plus an additional $\$ 1$ per acre. The lands are offered in leasing units as follows:

\section{ROOSEVELT HOT SPRINGS KGRA}

\section{Leasing Unit 非 $-\quad 2,560.00$ acres}

T. 26 S., R. 9 W., SL Mer., Utah

Sec. 15, A11;

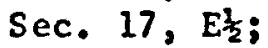

Sec. $20, E \frac{1}{2}$;

Sec. 21, All;

Sec. 22, All.

Leasing Unit \#2 $\quad 1,640.00$ acres

T. 26 . ., R. 9 W., SL Mer., Utah

Sec. 27, A11;

Sec. 28, All;

Sec. $29, E_{\frac{1}{2}}, S E_{\frac{1}{2}}^{\frac{1}{4}} S_{W \frac{1}{4}}$

Leasing Unit $\$ 3 \quad 1,920.00$ acres

T. 26 S., R. 9 W., SL Mer., Utah

Sec. 23, All;

Sec. 24, A11;

Sec. 26, All.

\section{Leasing Unit $\# 4 \quad 2,453.53$ acres}

T. $26 \mathrm{~S} .$, R. $9 \mathrm{~W}$, , SL Mer., Utah

Sec. 33, A11;

Sec. 34 , Lots $1,4,5,6,7, E_{\frac{1}{2}} N E \frac{1}{4}, N W \frac{1}{4} N E^{\frac{1}{4}}, N \frac{1}{2} N W \frac{1}{4}, S W \frac{1}{4} N W \frac{1}{4}, W_{\frac{1}{2}} S W \frac{1}{4}$;

Sec. 35, All.

T. 27 S., R. 9 W., SL Mer, Utah

Sec. 3, All;

Sec. 4, Lot 1. 
T. 26 S., R. 9 W., si Mer., Utah

Sec. 30 , Lots $1,2,3,4, E_{1}^{1} N^{\frac{1}{4}}, N^{\frac{1}{4}} S W^{\frac{2}{4}}$;

Sec. 31 , Lots $3,4, E_{\frac{2}{2}}^{\frac{1}{S}} W_{\frac{1}{4}}, S E \frac{\frac{1}{4}}{4}$.

T. 27 S., R. 9 W., SL Mer., Utah Sec. 6, All;

Sec. 7 , Lots $1,2, N E \frac{1}{4}, E_{\frac{1}{2}}^{1} N W^{\frac{2}{4}}$.

Leasing Unit \# 6

$1,939.65$ acres

T. 27 S., R. 9 W., SL Mer., Utah

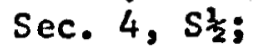

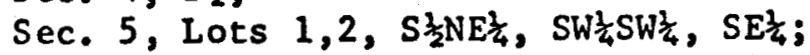

Sec. 8, A11;

Sec. $9, N \frac{1}{2}, S W \frac{1}{4}, E_{\frac{1}{2}}^{\frac{1}{2}} S E \frac{1}{4}, N W \frac{1}{4} S E_{\frac{1}{4}}$.

Leasing Unit 非 $\quad 1,961.40$ acres

T. 27 S., R. 2 W., SL Mer., Utah

Sec. 1, Al1;

Sec. 10, A11;

Sec. 11, All.

Leasing Unit 非 $\quad 2,272.50$ acres

T. 27 S., R. 9 W.; SI Mer., Utah

Sec. 17, A11;

Sec. 18 , Lots $1,2, N E \frac{1}{4}, E_{2}^{1} N_{W} \frac{1}{4}$;

Sec. 19, Al1;

Sec. 20, All.

Leasing Unit \#9 $\quad 1,920.00$ acres

T. 27 S., R. 9 W., SL Mer., Utah

Sec. 21, A11;

Sec. 28, A11;

Sec. 29, A11.

Leas ing Unit \#10

$2,560.00$ acres

T. 27 S., R. 9 W., SL Mer., Utah

Sec. 14, A11;

Sec. 15, A1:;

Sec. 22, All;

Sec. 23, All.

Leasing Unit 非11 $\quad 2,480.00$ acres

T. 27 S., R. 9 W., SL Mer., Utah

Sec. $25, E \frac{1}{2}, N W \frac{3}{4} N W \frac{1}{\frac{1}{4}}, S \frac{1}{2} N W \frac{1}{4}, S W \frac{1}{4}$;

Sec. 26, A11;

Sec. 27, A11;

Sec. $35, N \frac{1}{2}, S W \frac{1}{4}, N_{\frac{2}{2}}^{2} S E \frac{1}{4}, S^{\frac{1}{4}} S E_{\frac{1}{4}}^{\frac{2}{4}}$. 
Leasing Unit $\# 12$

T. 27 S., R. 9 W., SL Mer., Utah Sec. 9, SW $\frac{1}{4} \mathrm{SE}_{4}^{2}$

Attention is directed to the following leasing unit, which is subject to application for conversion richts (Grandfather rights) under 43 CFR 3230:

Leasing Unit 非12 Applicant: A. L. McDonald \& William L. McDonald P. 0. Box 521

Milford, Utah 84751

Four geothermal exploration drill holes have been drilled in the following locations:

(GREP \#1-7) Sec. 7, T. 27 S., R. $10 \mathrm{~W}$, ;

(GREP \#1-21) Sec. 21, T. 26 S., R. 9 W.;

(GREP \#1-24) Sec. 24, T. $26 \mathrm{~S},, \mathrm{R}, 11 \mathrm{~W}$, ; and

(GREP 非1-29) Sec. 29, T. 27 S., R. 9 W.

Lithologic logs on all four drill holes and temperature gradients on holes GREP 1 1-29, 非 $1-24$ and 1 1-7 are available for inspection at the Utah State office. This information is also available by written request to this office.

Form 1140-3, Certification of Nonsegregated Facilities, will be made a part of any lease issued, and compliance with its provisions will be required effective upon execution of the lease. Identical certifications must be obtained from proposed subcontractors prior to the award of subcontracts exceeding $\$ 10,000$ which are not exempt from the provisions of the Equal Opportunity clause.

\section{SPECIAL STIPULATIONS AND CONDITIONS}

In addition to lease terms and requirements contained in the lease form, the lessee shall comply with the following special conditions and stipulations unless they are modifled by mutual agreement of the lessee, the Supervisor and the authorized officer.

1. The lessee shall provide a complete inventory and evaluation of archaeological and historical values on lands to be disturbed or occupied. this will be prepared by a competent archaeologist, acceptable to the authorized officer, in advance of any surface disturbance.

2. A11 survey monuments, witness corners, reference monuments and bearing trees will be located by the lessee in advance of surface disturbance and protected against destruction, obliteration or damage. Any markers accidentally damaged or obliterated by the lessee or his operator must be re-established in accordance with instructions of the responsible agency at the expense of the lessee.

3. Natural drainage systems shall not be blocked. No cuts or fills shall 
be made in or near streams which will result in siltation or accumulation of water or debris.

4. The lessee shall make every possible effort to prevent control or suppress any fire on national resource lands within the operating area. Reports of uncontrolled fire must be immediately sent to the BLM District office, Fillmore, Utah.

5. The authorized offlcer may require temporary fencing of areas to alleviate hazards to humans, livestock or wildlife or to allow seedlings on rehabilitated areas to become established.

6. Existing surface waters in pipelines, storage tanks, ponds. reservoirs or streamis are not avallable for use in any activities under this lease except as may be specifically permitted by the authorized officer.

Copies of lease and bond forms, regulations, and bid forms may be obtained from the office of the State Director, Bureau of Land Management, Salt Lake City, Utah.

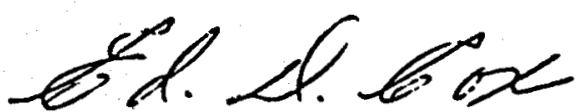

Ed. D. Cox, Chief

Branch of Realty Services 
R. 10 W.

R. 9 W.

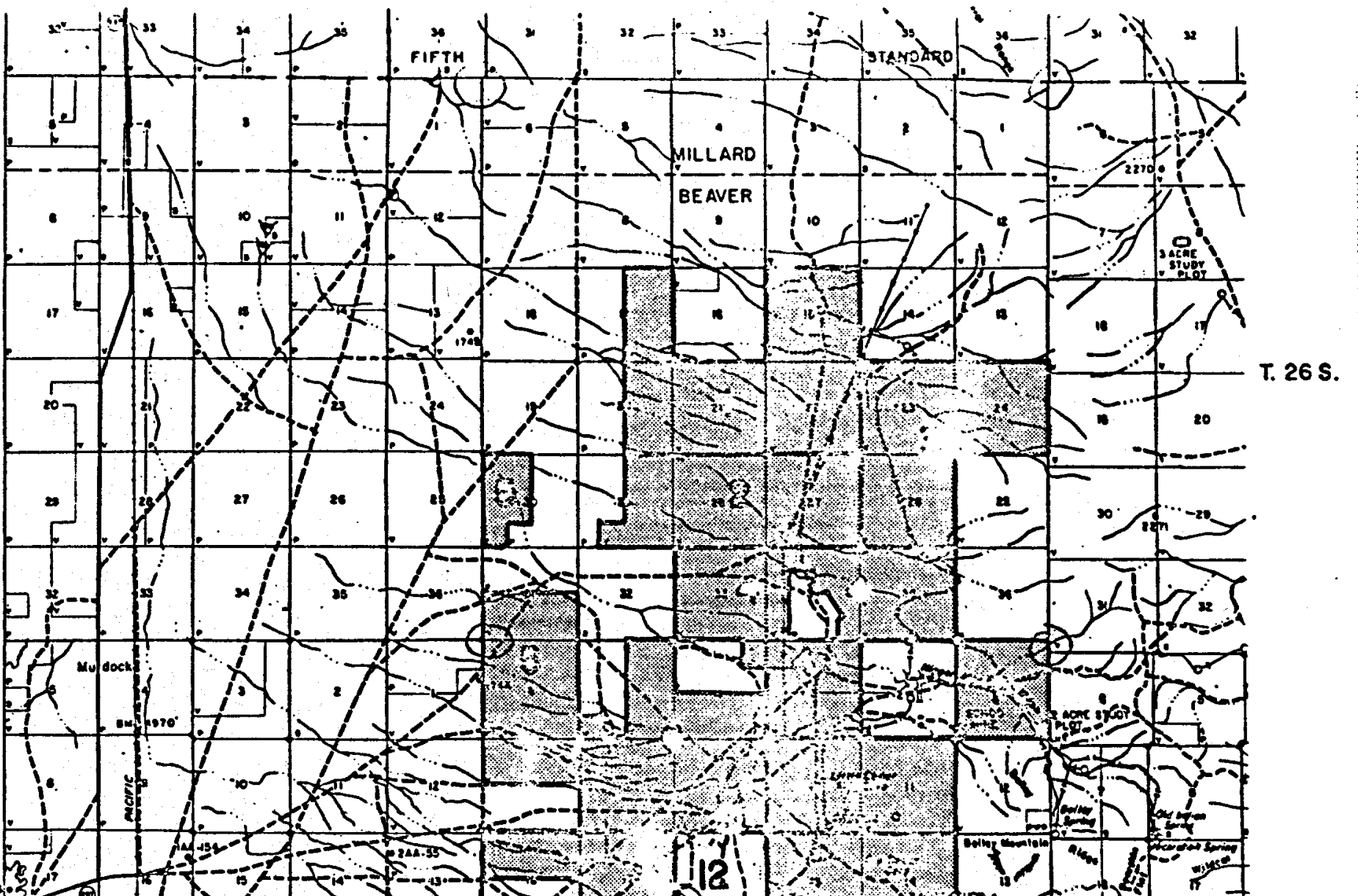

of

is

$150^{-20}$

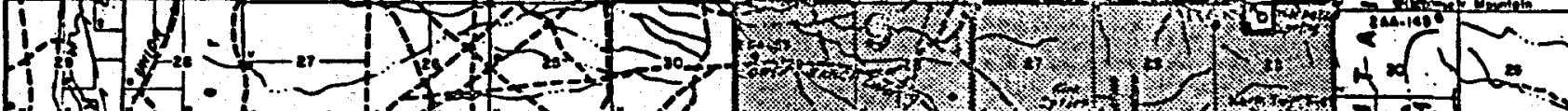

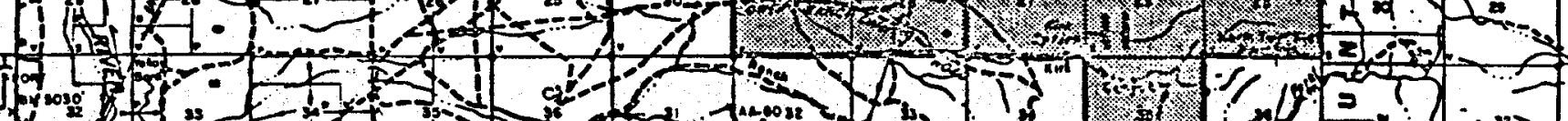
-5)

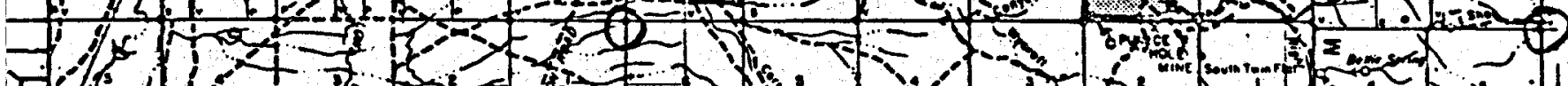

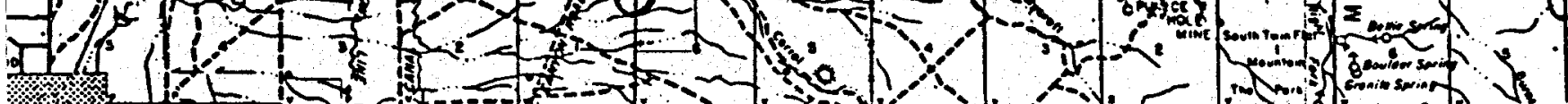
$x$

*.. $\mathrm{H}$ H UTAH GEOTHERMAL RESOURCE LEASE SALE

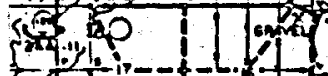

Alin.

$0.0+1.0$ SALE NO. 1

ROOSEVELT HOT SPRING KGRA

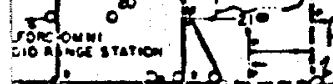

i.

2. I. I.:

I4) SALE UNITS 


\author{
SPECIAL STIPULATIONS AND CONDITIONS \\ THERMO, LUND, MONROE-JOSEPH AND ROOSEVELT KGRA'S
}

\title{
General
}

In addition to lease terms and requirements contained in the lease form, the lessee shall comply with the following special conditions and stipulations unless they are modified by mutual agreement of the lessee, the Supervisor (USGS) and the Bureau of Land Management.

\section{Special Stipulations}

1. Notwithstanding any provision of this lease to the contrary, any drilling, construction, or other operation on the leased lands that will disturb the surface thereof or otherwise affect the environment, hereinafter called "surface disturbing operation," conducted by lessee shall be subject, as set forth in this stipulation, to prior written approval of such operation by the Area Geothermal Supervisor and the Surface Management Agency and to such reasonable conditions, not inconsistent with the purposes for which this lease is issued, as the Area Geothermal Supervisor and the Surface Management Agency may require to protect the surface of the leased lands and the environment.

2. Prior to commencing any operations on the leased lands or on any lands covered by a unit or cooperative agreement, the lessee shall submit in triplicate a map and explanation of the nature of the anticipated activity and surface disturbance and obtain the approval of the Area Geothermal Supervisor, Conservation Division, Geological Survey, 345 Middlefield Road, Menlo Park, Callfornia 94025, and the appropriate Surface Management Agency.

\section{Surface Management Agency (Name and Address)}

3. Environmental analysis, as appropriate, will be made by the Geological Survey in consultation with the Surface Management Agency for the purpose of assuring proper protection of the surface, the natural resources, the environment, existing improvements, and for assuring timely reclamation of disturbed lands. Upon completion of the environmental analysis, the Area Geothermal Supervisor shall notify lessee of further conditions, if any, to which the proposed surface disturbing operations will be subject.

\section{Cultural Resources}

The lessee will comply with all existing state or federal laws pertaining to the protection of cultural and paleontological values, specifically the Historic Preservation Act of 1966: Prior to entry upon the land or disturbance of the surface thereof, inventory of all archaeological, paleontological and historical values will be made of those areas of the lease subject to development, occupancy or surface disturbance. 
The survey will be completed by a qualified archaeologist acceptable to the BLM. The results and information of this survey will be provized to the BLM and the Area Geothermal Supervisor. The lessee will be required to take such steps as necessary to preserve or avoid destruc:ion of antiquities such as relocation of proposed facilities, salvage of artifacts or other measures deemed necessary. All costs of the surve; and salvage of artifacts will be borne by the lessee and all objects of antiquity salvaged from the national resource lands will remain. the property of the U.S. Government.

Special consideration of archaeological resources will be given in leasing units 3 and 4 of the Thermo Hot Springs KGRA.

\section{Access - Roads}

(a) The use of existing roads or trails and the construction of all new roads necessary for the exploration of the lease lands shall receive approval prior to construction by the Area Geothermal Supervisor and the BLM. The BLM will determine the location and set forth the road standards and construction methods employed.

(b) Maintenance of such roads shall be the responsibility of the lessee unless otherwise specified. A regular maintenance program or upgrading of existing roads such as, but not limited to ditching, draining, culverts, gravelling, or capping of the road bed may be required.

(c) The authorized officer of the Surface Management Agency will determine the final disposition of all roads upon termination of the lessee's operations or lease and may prescribe the final conditions of abandonment.

(d) The BLM may require installation of cattle guards at fence crossings.

(e) Off-road vehicle travel in erosion hazardous areas or where vegetation would be adversely impacted will be restricted to that approved by the BLM.

\section{Water Quality}

(a) Disturbance of drainages and high erosion hazardous àreas shall be avoided. Surface construction or land disturbance activities shall not occur within any flood plain or channel of any water course except at stream crossing, designated by the Surface Management Agency. Drainages shall not be blocked nor shall the lessee cause the siltaticn or accumulation of debris in the drainage channels. 
(b) No water located on, or flowing through the public lands shall be obtained for the exploration, development or operation of the lease lands unless approved by the authorized officer of the Surface Management Agency.

(c) No drilling or extended human activity will be allowed within 400 feet of surface water in streams, reservoirs, seeps, springs, irrigation canals, etc. The distance may be reduced when specifically approved in writing by the authorized officer of the Surface Management Agency and the Area Geothermal Supervisor.

7. Rehabilitation

(a) Upon cessation of the use of all or any part of the lease surface for construction, exploration or operation, all disturbed areas will be reclaimed to a productive land use or to a state approximating former condition as approved or directed by the Area Geothermal Supervisor and the BLM.

(b) The Area Geothermal Supervisor and BLM may approve or prescribe such construction and rehabllitation methods and practices as determined necessary to achleve desired reclamation results. Reclamation is critically site specific, therefore, special stipulations may include determination of the final topography, drainage system, revegetation methods, soil treatments and amendments, stockpiling of topsoil, segregation of spoil materials, surface manipulations, waste disposal and other practices. deemed necessary to rehabilitate disturbed areas.

(c) All support facilities, structures, storage yards, and similar equipment and facilities will be removed from the national resource lands within one year of the final termination of use unless otherwise extended or directed by the Area Geothermal Supervisor: Areas occupied by such facilities wlll be rehabilitated in accordance with rehabilitation stipulations.

\section{Existing Improvements}

All existing improvements including but not 1 imited to fences, gates, cattleguards, roads, trails, pipelines, bridges, water developments, campgrounds or other improvements placed on the national resource lands to facilitate their use shall not be disturbed unless authorized by BLM. Where disturbance or use is made of such facillties, they shall be left in their orlginal or better condition. Damaged or destroyed improvements shall be replaced, restored or appropriately compensated for at the discretion of the BLM. 


\section{Cadastral Survey Corners and Monuments}

All survey monuments, witness corners, reference monuments and bearing trees must be protected against destruction, obliteration or damage. Any damaged or obllterated markers must be re-established at the lessee's expense, in accordance with accepted BLM survey practices as set forth in the Manual of Surveying Instructions. A complete record of the monumentation and the methods used in re-establishment will be furnished to the Chief, Branch of Cadastral'survey at the appropriate State Director's office, BLM.

\section{Fire Control.}

The lessee shall make reasonable effort to prevent, control or suppress any fire on forest or range lands. Reports of uncontrolled fire must be immediately sent to the District Manager. BLM.

The lessee is responsible for suppression and rehabilitation costs for any fires on the public lands caused by the negligence of his operators, employees, contractors or subcontractors.

\section{Wildife Protection}

In order to protect winter deer habitat, all exploring, drilling, and other development activity will be limited to the period from April 15 to November 30. This limitation does not apply to maintenance and operation of producing geothermal wells. Exceptions to this time limitation in any year may be altered in writing by the BLM.

Applicable only in Monroe-Joseph KGRA to leasing units: 1 (Sec. 22 W/ NWt NWtSWt, T. 25 S., R. 4 W.) , 2,3 and 4 . 

$\therefore 15686$

Exhibit " $\because$ "

\section{SPECIAL STIPULATIONS}

Timberline Lodge Area - Mt. Hood National Forest

The following spectal stipulations attached to and made a part of Geothermal Lease, OR 15686, are in addition to and not in derogation of the lease terms and requirements contained in Lease Form 3200-21. The Inssee shall comply with the following special conditions and stipulations unless they are modified by mutual agreement of the Lessee, Supervisor and Authorized Officers of the Bureau of Land Management and Forest Service.

1. The Lessee will comply with all Federal laws pertaining to the protection of archaeological, paleontological and historical values, including but not limited to the Antiquities Act (16 U.S.C. 431433) and the Historic Preservation Act of 1966. Prior to disturbance of the surface, or entry on the land for any purpose other than "casual use" (as that term is defined in 43 CFR 3209.0-5), the Lessee will be required to have a survey made of all archaeological, paleontological and historical values in those areas of the lease which the Lessee proposes for surface disturbance, occupancy, or development. The archaeologist making such survey must be acceptable to the Forest Supervisor, and must furnish to the Forest Supervisor and the Area Geothermal Supervisor a certified statement setting out the steps taken in the survey and the findings thereof 8s to the existence of any such values. If the statement indicates the existence of any such values which might be disturbed, the Lessee shall take such steps to protect and preserve those values as may be required by the Forest Supervisor and the Area Geothermal Supervisor, or by such other officer as may be designated by the Secretary of the Interlor. These steps may include protective measures such as complete avoidance of the site, relocation of proposed facilities, or salvage of the objects in accordance with applicable lews and regulations.

2. All the commerclal uses of geothermal resources for space heating, snow removal, or for any other purposes requiring transportation of geothermal flulds derived from the lands in this lease shall be confined to the Timberline Lodge Complex, unless otherwise stipulated by mutual agreement of the Lessee, the Lessor, the Forest Supervisor, and the Area Geothermal Supervisor. 
3. In addition to the definition found in Section 5 of this lease document and as defined in the regulations under 43 CFR 3000.0$5(f)$, the term "Authorized of $f$ icer" as used in this lease for the lands whose surface is managed by an agency other than the Bureau of Land Management 1s: (a) For sections 5 and 11, the Authorized Officer of the Bureau of Land Management; (b) For sections 12, 14 and 18 involving surface management responsibilities, the Authorized Officer of the surface management agency (Forest Service). 
Mt. Hood Planning Unit

Mt. Hood National Forest

The following special stipulations, attached to and made a part of serialized geothermal lease OR , are In addition to, and not in derogation of, the lease terms and requirements contained in the Lease Form 3200-21. The Lessee shall comply with the following special conditions and stipulations unless they are modified by mutual agreement of the Lessee, the Supervisor, the Surface Management Agency (USFS), and Authorized Officer:

1. The Lessee agrees not to occupy or use the surface of leased lands except for certain limited uses as authorized in writing by the Forest service, until (1) the Forest service completes the land management plan, (2) there is compliance with the National Environmental Policy Act of 1969 (42 U.S.C. 4231); (3) the stipulation is modified, supplemented or eliminated or it has been determined to retain it unchanged; and if applicable (4) Bull Run Reserve legislation provides longterm direction for geothermal activity within the reserve and the existing Court Decree is either complied with or lifted, and (5) Congress completes action on the existing zigzag Mountain Wilderness Bill.

2. To minimize the effect of surface disturbance, temperature gradient holes shall be drilled with small or medium sized truck-mounted arill rigs. . । 
APPENDIX D

MONO-LONG VALLEY 


\section{APPENDIX D-1}

June 1973 Contact by BLM to help on Programmatic E.I.S.

Sept 1973 Memo to BLM of stipulation of "No Lease" until Monoplan is complete.

Oct 1973 Request to R.0. for Geothermal funds - (denied). BLM Programmatic E.I.S. issued.

Nov 1973 Trip to Cerro Prieto, Mexico, to observe Geothermal operations.

Dec 1973 AGU Meeting - first announcement by U.S.G.S. of research findings in Long Valley.

Jan 1974 Lease sale - BLM - Long Valley.

Apr 1974 Letter to BLM - update on Monoplan - target date December 1, 1974, including E.I.S.

July 1974 Letter to R.F. on Inyo position on Geothermal.

Oct 1974 Memo to Region on delay - no evaluation by U.S.G.S. available.

Dec 1974 Memo of update to R.F. on Geothermal activity, Including proposal to meet with industry.

Jan 1975 Develop strategy with Towle as to how to proceed.

Feb 1975 Meeting with industry to outline position.

Feb 1975 Request for substantial funding for Inyo to do Geothermal activities.

Feb 1975 Response by U.S.G.S. as to potential and location of Geothermal resource.

Mar 1975 E.D. No. 4 .

Mar 1975 Memo request by R.O. to P.S.W. on air quality.

Mar 1975 Letter from R.F. to Chlef on Geothermal.

Apr 1975 Response by W.0. on budget request for Geothermal.

June 1975 Start air quality work by PSW - Tom Palmer.

June 1975 Plan of action - Geothermal.

July 1975 Contract with Clyde Kuhn - Archaeological Survey.

Aug 1975 Plan of action with BLM - decision to join BLM in E.I.S. 
Sept 1975 R.O. memo to W.O. - explains thinking on funding and frustrations.

Oct 1975 Public involvement for input to E.A. - decision to go to E.I.S.

Dec 1975 First report by Archaeologist Kuhn - first sign of trouble with contract.

Feb 1976 Memo update of critical path to September 1, 1976.

Feb 1976 Final report by Archaeologist Kuhn.

May 1976 Request and justification statement to E.R.D.A.

June 1976 Rejection of Kuhn report.

June 1976 Cooperative Agreement between Forest Service and Dept. of Energy for transfer of $\$ 37,000$ to Forest Service for assistance on Geothermal E.I.S.

July 1976 Archaeology Contract to begin with UC - Riverside.

Sept 1976 Archaeology Contract complete.

Nov 1976 Passage of National Forest Management Act.

Dec 1976 Mono Plan approved by County.

Jan 1977 Information from Cal. State Dept. of Fish and Game and Air Quality Data via Lawrence Livermore Laboratory had not been transmitted to Inyo National Forest.

Feb 1977 Information recelved from California Dept. of Fish and Game.

Oct 1977 Decision by Regional Forester, R-5, that:

1. Determination of avallability and suitability for geothermal leasing will be through the Land Management Planning process.

2. Determination of specific areas to lease will be through an Environmental Analysis Report.

Nov 1977 Land Management Planning team organized.

July 1978 Draft Land Management Plan E.S. sent to E.P.A. This includes alternatives dealing with a major issue concerning geothermal leasing.

July 1978 Continue geothermal leasing E.A.R. process which began July 1976.

Oct 1978 File final E.S. of LMP with E.P.A.

Nov 1978 Complete geothermal EAR and decision for leasing. 


\section{$D-2$}

SUMMARY TABLE - Analysis of Implementation Effects

\begin{tabular}{|c|c|c|c|c|c|c|}
\hline \multirow{2}{*}{ ENVIRONMENTAL CHANGES } & \multicolumn{6}{|c|}{ ALTERNATIVES } \\
\hline & $\mathbf{I}$ & II & III & IV & $\mathbf{v}$ & VI \\
\hline Physical and Biologic & & & $\oplus$ & & & \\
\hline Social & C & O & P & & & c \\
\hline Economic & & & 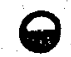 & $\theta$ & $\mathrm{C}$ & $C$ \\
\hline ENVIRONMENTAL SUMMARY & $\Omega$ & & $\oplus$ & 8 & & 8 \\
\hline
\end{tabular}

KEY $Q=$ Most significant beneficial changes

$\delta=$ significant beneficlal changes

$\oiint=$ Least significant beneficial changes

$O=$ Insignificant beneficial changes

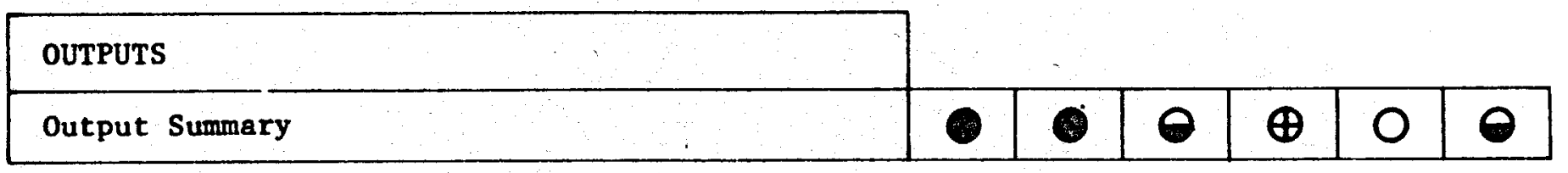

KEY $=$ Most significant output yield

$Q=$ significant output yield

$\oiint=$ Least significant output yield

$O=$ Insignificant output yield

\begin{tabular}{|l|l|l|l|l|l|l|l|}
\hline Costs & \multicolumn{7}{|l|}{$\mid$} \\
\hline Cost summary & $\oplus$ & 0 & 0 & $\oplus$ & 0 & $\oplus$ \\
\hline
\end{tabular}

KEY $Q=$ Lowest costs

$=$ Low costs

$\oiint=$ Moderate costs

$\mathrm{O}=\mathrm{High} \cos t s$

\section{OVERALL \\ ANALYSIS \\ SUMMARY}

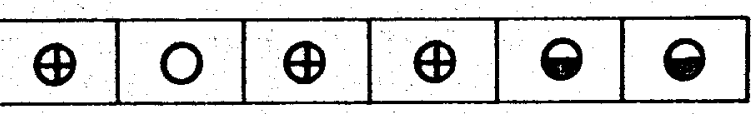

KEY $\quad=$ Highest overall analysis summary rating

$8=$ High overall analysis summary rating

$\oiint$ - Moderate overa11 analys is sumary rating

. Low overall analysis sumary rating 
CRITERION 1 - Dealing with Issues of Major Concern

\begin{tabular}{|c|c|c|c|c|c|c|}
\hline \multirow{2}{*}{ ISSUES } & \multicolumn{6}{|c|}{ ALTERNATIVES } \\
\hline & I & II & III & IV & V & VI \\
\hline $\begin{array}{l}\text { RECREATION DEVELOPMENT } \\
\text { Providing quality recreation opportunities, both } \\
\text { winter and summer, commensurate with public } \\
\text { demand and capability of the land to accomodate } \\
\text { such activity }\end{array}$ & & & & & & \\
\hline $\begin{array}{l}\text { GEOTHERMAL DEVELOPMENT } \\
\text { Providing suitable lands for geothermal devel- } \\
\text { opment which are commensurate with maintaining } \\
\text { other resource values }\end{array}$ & & & $\oplus$ & & & \\
\hline \multirow{3}{*}{$\begin{array}{l}\text { MONOPLAN } \\
\text { Acceptance of the Monoplan by the Forest Service } \\
\text { ("REGIONAL" and "URBAN" portions of the Monoplan } \\
\text { considered separately) }\end{array}$} & \multicolumn{6}{|c|}{ "REGIONAL" } \\
\hline & & $\theta$ & & & $\oplus$ & \\
\hline & \multicolumn{6}{|c|}{ "URBAN" } \\
\hline $\begin{array}{l}\text { JUNE LAKE LOOP GENERAL PLAN } \\
\text { Acceptance of the June Lake Loop General Plan } \\
\text { by the Forest Service }\end{array}$ & & & & & & \\
\hline ISSUES SUMMARY & & $\oplus$ & 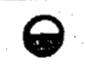 & & & \\
\hline
\end{tabular}

KEY $Q=$ Most significant dealing with issues of major concern

$\gamma=$ Significant dealing with issues of major concern

$\oiint=$ Least significant dealing with issues of major concern

- Insignificant dealing with issues of major concern 


\begin{tabular}{|c|c|c|c|c|c|c|}
\hline \multirow{2}{*}{ RPA GOAL FOR RANGE* } & \multicolumn{6}{|c|}{ ALTERNATIVES } \\
\hline & $\mathbf{I}$ & II & III & IV & v & VI \\
\hline $\begin{array}{l}\text { "Emphasize management practices and development } \\
\text { that Increase red meat supply, to the extent } \\
\text { benefits are commensurate with costs" }\end{array}$ & e & & & & $\bigoplus$ & \\
\hline RPA GOALS FOR TIMBER* & & & & & & \\
\hline $\begin{array}{l}\text { "Use intensive management to provide a moderate } \\
\text { Increase in timber supplies on National Forest } \\
\text { System lands to the extent that benefits are } \\
\text { commensurate with costs" }\end{array}$ & & & & & & \\
\hline $\begin{array}{l}\text { "Discourage diversion of prime timberlands to } \\
\text { other use" }\end{array}$ & & & & & & \\
\hline TIMBER SUMMARY & & & & & & \\
\hline
\end{tabular}

RPA GOAL FOR WATER*

"Selectively Improve water supply, commensurate with benefits"

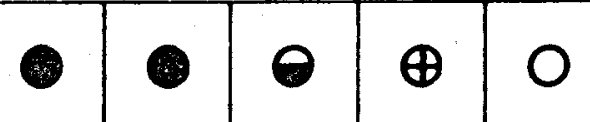

RPA GOAL FOR MINERALS*

"Improve cooperation, coordination, and planning of mineral extraction activities by fully

Integrating them with other resources, opportunItles and needs"
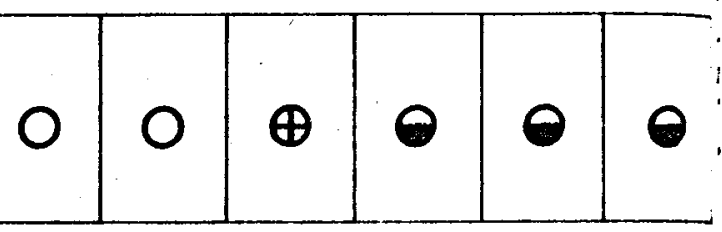

\section{GOAL FOR GEOTHERMAL**}

Make those lands avallable for geothermal development which have been Identifled as possessing the greatest potential
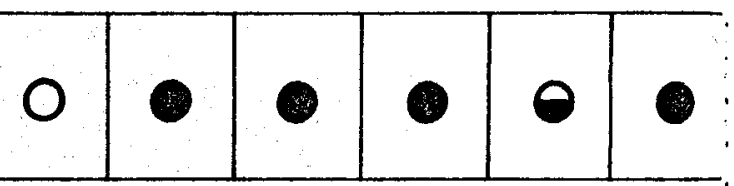

RPA GOAL FOR HUMAN AND COMMUNITY DEVELOPMENT*

"Provide a moderate level of employment opportunltles for special employment groups such as youth, older Americans, and the disadvantaged"

TOTAL GOAL SUMMARY

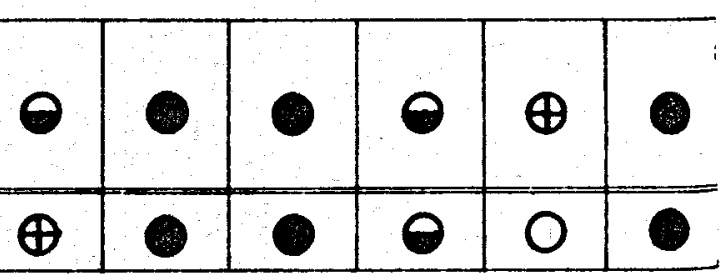

* Only applicable and pertinent RPA goals are considered.

** Not an RPA goal, but Included here because of the importance of geothermal considerations in the MMPU.

KEY = Most significant contribution to RPA goal attainment

$Q=$ Significant contribution to RPA goal attainment

$\Phi=$ Least significant contribution to RPA goal attainment

= Insignificant contribution to RPA goal attalnment 
CRITERION 3 - Ylelding Outputs for Contributing to RPA Target Attainment

\begin{tabular}{|c|c|c|c|c|c|c|}
\hline \multirow{2}{*}{ OUTPUT PRODUCING ELEMENT } & \multicolumn{6}{|c|}{ ALTERNATIVES } \\
\hline & $\mathbf{I}$ & II & III & IV & $\mathbf{v}$ & VI \\
\hline Recreation (RVD at developed sites) & & & & (2) & & \\
\hline Recreation (RVD at dispersed areas) & & & $\oplus$ & Q & O & \\
\hline Recreation (RVD at VIS sites) & & & $\oplus$ & Q & $\boldsymbol{\theta}$ & \\
\hline Wilderness (RVD of wilderness use) & & & & & & \\
\hline Geothermal (Acres available for development) & & & & $\oplus$ & & \\
\hline Range (AUM produced) & & & & $\theta$ & & \\
\hline Timber Products (MMBF produced) & & & & $\oplus$ & & \\
\hline OUTPUT SUMMARY & & & & $\boldsymbol{\oplus}$ & $\mathbf{O}$ & \\
\hline
\end{tabular}

KEY $\quad=$ Most significant contribution to target attainment

$Q=$ significant contribution to target attainment

$\oiint=$ Least significant contribution to target attainment

$\mathrm{O}=$ Insignificant contribution to target attainment

CRITERION 4 - Passing Tests of Feasibility

\begin{tabular}{|c|c|c|c|c|c|c|}
\hline \multirow{2}{*}{ TESTS } & \multicolumn{6}{|c|}{ ALTERNATIVES } \\
\hline & $\mathbf{I}$ & II & III & IV & $\mathbf{v}$ & VI \\
\hline $\begin{array}{l}\text { LEGAL } \\
\text { Can the alternative plan be implemented within } \\
\text { the constraints of current law, rules and } \\
\text { regulations? }\end{array}$ & & & & & & \\
\hline $\begin{array}{l}\text { TECHNICAl } \\
\text { Can the alternative plan be carried out under } \\
\text { current technology or w11l new technology have } \\
\text { to be developed? }\end{array}$ & & & & & & \\
\hline $\begin{array}{l}\text { FINANCIAL } \\
\text { Can sufficlent funds be reasonably expected to } \\
\text { implement this alternative plan? }\end{array}$ & & $\boldsymbol{\oplus}$ & & & & \\
\hline $\begin{array}{l}\text { POLITICAL } \\
\text { Will this alternative plan be supported by the } \\
\text { general public and local governmental agencies? }\end{array}$ & & & & & & \\
\hline FEASIBILITY SUMMARY & & $\oplus$ & & & & \\
\hline
\end{tabular}

KEY

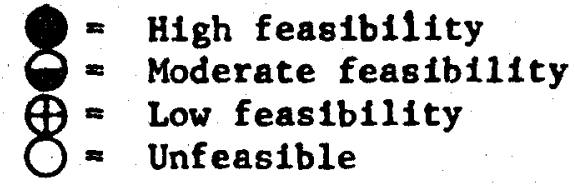


Results of the overall evaluation considering all criteria are summarized on the the following table:

$$
\text { SUMAARY TABLE - Results of Evaluation }
$$

\begin{tabular}{|c|c|c|c|c|c|c|}
\hline \multirow{2}{*}{ EVALUATION CRITERIA } & \multicolumn{6}{|c|}{ ALTERNATIVES } \\
\hline & $\mathbf{I}$ & II & III & IV & $\mathbf{v}$ & VI \\
\hline 1. Dealing with issues of major concern & & $\oplus$ & & & & \\
\hline 2. Contributing to RPA Goal Attainment & $\theta$ & & & & & \\
\hline $\begin{array}{l}\text { 3. Ylelding Outputs for Contributing to RPA } \\
\text { Target Attainment }\end{array}$ & & & & $\oplus$ & & \\
\hline 4. Passing Tests of Feasibility & & 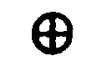 & & & & \\
\hline $\begin{array}{l}\text { 5. Resulting in the Least Adverse Environmental } \\
\text { Effects on the Physical and Blological } \\
\text { Environment }\end{array}$ & & & $\oplus$ & & & \\
\hline $\begin{array}{l}\text { 6. Resulting in the Most Beneficial Changes in } \\
\text { the Social Environment }\end{array}$ & & & & & & \\
\hline 7. Resulting in the Highest Economic Growth & & & & $\oplus$ & & \\
\hline OVERALL EVALUATION SUMMARY & & $\oplus$ & & & & \\
\hline
\end{tabular}

KEY TO OVERALL EVALUATION

= Most significant response to evaluation criteria

= Significant response to evaluation criteria

$\oiint$ - Least significant response to evaluation criteria

8 - Insignificant response to evaluation criteria 
Alternative I

Alternative II

Alternative III

Alternative IV

Alternative $V$

Alternative VI
The strongest response of Alternative I to the evaluation criteria is yielding outputs and contributing to economic growth. There is also a strong response to dealing with issues. A weak response is shown for RPA goal attainment. This al ternative shows the weakest response to creating social benefits, reducing potential adverse environmental effects and passing tests of feasibility. The alternative rated lowest of any other alternative in legal feasibility. Although this older plan (1971) was prepared in keeping with the existing law at that time (Multiple Use-Sustained Yield Act of 1960), it lacks the "capability" and "suitability" determinations which are now a requirement of a more recent law, (National Forest Management Act of 1976). For this reason, Alternative I was given a low mark in legal feasibility.

The strongest response of Alternative II is in contributing to RPA goal attainment, yielding outputs, and economic growth. A weak response is shown for dealing with issues and passing tests of feasibility. The reasons for the low mark in feasibility are the degree of development and related costs of implementation, which are the highest among alternatives. This al ternative shows the weakest response to reducing potential adverse environmental effects and creating social benefits.

The strongest response of Alternative III is in contributing to RPA goal attainment and passing tests of feasibility. There is also a strong response to dealing with issues, yielding outputs, economic growth and creating social benefits. This al ternative shows weak response to reducing potential adverse environmental effects.

The strongest response of Alternative IV is in dealing with issues, passing tests of feasibility, and creating social benefits. There is also a strong response to RPA goal attainment and posing the least adverse environmental effects. This al ternative shows a comparatively weak contribution to yielding outputs and achieving the highest economic growth.

The strongest response of Alternative $V$ is in posing the least adverse environmental effects and creating social benefits. There is also a strong response to passing tests of feasibility. Alternative $V$ is weaker than any other al ternative in dealing with issues, contributing to RPA goal attainment, yielding outputs and contributing to economic growth.

The strongest response of Alternative $V I$ is in dealing with issues, contributing to RPA goal attainment and passing tests of feasibility. There is also a strong response to yielding outputs, reducing potential adverse environmental effects, creating social benefits and contributing to economic growth. This al ternative shows no responses on the weak side of the evaluation spectrum. 


\section{IDENTIFICATION OF THE PREFERRED ALTERNATIVES}

Identification is based on results of the alternative analysis, evaluation, and professional judgement which considers public demands.

The following table summarizes these identification factors:

\begin{tabular}{|c|c|c|c|c|c|c|}
\hline \multirow{2}{*}{ IDENTIFICATION FACTORS } & \multicolumn{6}{|c|}{ ALTERNATIVES } \\
\hline & $\mathbf{I}$ & II & III & IV & $\mathbf{v}$ & VI \\
\hline $\begin{array}{c}\text { Results of Analysis (From summary table in } \\
\text { Analysis section) }\end{array}$ & $\oplus$ & & $\theta$ & $\Theta$ & & \\
\hline $\begin{array}{c}\text { Results of Evaluation (From summary table in } \\
\text { Evaluation section) }\end{array}$ & & $\oplus$ & & & & \\
\hline Professional Judgement Considering Public Demands & $\oplus$ & O & $\boldsymbol{\theta}$ & Q & $\mathbf{O}$ & \\
\hline SUMMARY & $\boldsymbol{\oplus}$ & 0 & Q & 8 & $\oplus$ & \\
\hline
\end{tabular}

KEY

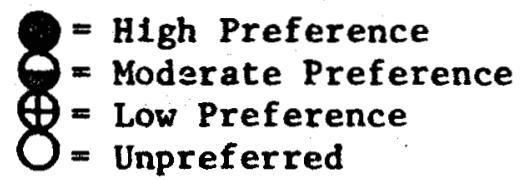

ALTERNATIVE I - Ranks low on the preference scale as a result of the analysis and professional judgement. This alternative also shows an unpreferred rating for evaluation results.

ALTERNATIVE II - Ranks low on the preference scale as a result of the evaluation. This alternative also shows unpreferred ratings for analysis and professional judgement.

ALTERNATIVE III - Ranks high on the preference scale as a result of the evaluation, but shows low preference ratings for analysis results and professional judgement.

ALTERNATIVE IV - Ranks high on the preference scale as a result of the evaluation and shows moderate preference ratings for professional Judgement, but shows a low preference rating for analysis results.

ALTERNATIVE V - Ranks moderate on the preference scale as a result of the analysis, but shows unpreferred ratings for evaluation results and professional judgement.

ALTERNAmIVE VI - Ranks high on the preference scale as a result of the evaluation and professional fudgement. This alternative also shows a moderate rating for analysis results.

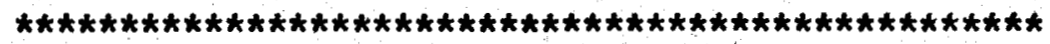

ALTERNATIVE VI - Presents the most balanced response to all criteria and shows the highest identification factor rating among all alternatives considered. It is also identified as the preferred alternative. 
APPENDIX E

COSO HOT SPRINGS 


\section{DEPARTMENT OF THE NAVY}

NAVAL WEAPONS CENTER

- china lake. california 93555

IN REPLY REFEA TO:

26/RBW:1da

$131-78 / 2$

11 May 1978

Ed Hastey, State Director

United States Department of the Interior

Bureau of Land Management

State Office

Federal Office Building

2800 Cottage Way

Sacramento, California 95825

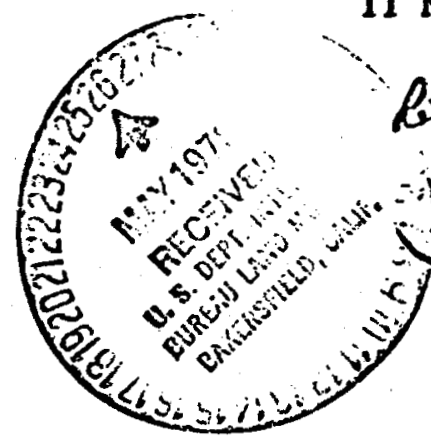

\section{Dear Ed:}

To] $\mid \overline{0} / \overline{0.0}$ ex 2 so $\therefore$

$\therefore$

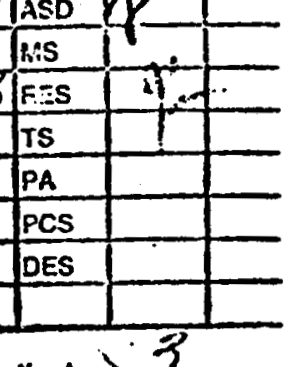

in the BLM/NWC MOU on Coso geothermal development.

The unanticipated workload resulting from Coso Hot Springs being placed on the National Register of Historic Places has resulted in a delay in finalizing the constraints.

Although RADM Harris has not given final approval, the enclosed constraints are the result of concerted staff effort to develop a workable and effective package. While we are obtaining the approval of RADM Harris, it would be beneficial to obtain your informal concurrence and/or comments on the proposed addition to the MOU. If you desire, I will be glad to meet with you to discuss these constraints.

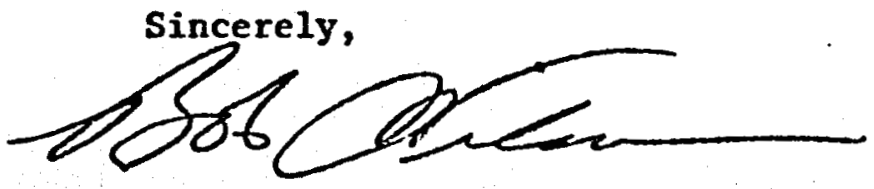

\section{R. B. HILSON}

Enclosure:

(1) Navy Constraints on Geothermal Operations on Navy Lands

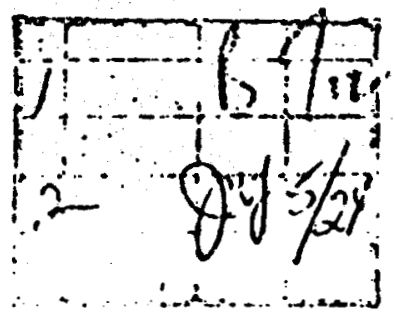




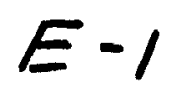

\author{
Navy Constraints on Geothermal Operations \\ on NWC Lands
}

\title{
1. General
}

Constraints will be placed on geothermal operations within the boundaries of the Naval Weapons Center to ensure the safe and economical development and production of those geothermal resources within the NWC boundary and ensure that any leasing, development and production does not conflict with the mission of NWC.

\section{Administrative Responsibility}

The Commander, NWC, is the responsible agent of the Federal Government for the utilization of the land and airspace of NWC. As such, the Commander, NWC, is responsible for the protection of the health and safety of all personnel, military and civilian, within the confines of NWC, and is responsible for the continuing preservation of the ability of NWC to perform its mission of Air Weapons RDT\&E.

\section{Access}

Access to the NWC is a privilege granted by Commander, NWC. Exercise of this priviledge requires adherence to NWC traffic regulations, check in/check out procedures, radiation control measures, environmental controls, area access limitations, and electronic emission controls and such other published administrative regulations as appropriate. Access shall be on a not-to-interfere basis with NWC test schedules, and shall be limited to that specific lease block or area being explored, developed or produced. Access schedules shall be established on a weekly basis with NWC. NWC shall provide for emergency access for reasons of geothermal safety or other drilling incidents requiring uninterupted short term access to a specific site or geothermal operation. Experlence to date shows in any given month, unscheduled daylight downtime will not regularly exceed $10 \%$ and unscheduled nighttime downtime will not regularly exceed $2 \%$. Access shall require that for each lease holder, one responsible contact point shall at all times know who is present on NWC lands, and this contact point shall be reachable at all times in event evacuation is ordered.

\section{Security}

The mission of the NWC is such that visitors cannot be granted access to NWC lands without going through NWC security procedures. All non-citizen visits must be arranged through NWC with a minimum notice of 48 hours for non-commist-bloc visitors. The latter will be considered on a case by case basis. The accessible areas and routes to and from work areas. within lease blocks shall be approved by NWC. 


\section{Environmental}

All vehicular traffic shall be limited to routes approved by NWC. NWC retains the right to suspend any operation judged by the Center to present an imminent threat to the environment. During all operations, all federal, state and local environmental requirements shall be rigorously observed. No components of the environment shall be unnecessarily disturbed. NWC shall have the right to impose those emmission standards required to protect the Center's mission.

\section{Sites and Routes}

Power plant sites, drill pad sites and pipe line routes will be selected subject to NWC approval to ensure such sites will have a minimum impact on NWC range operations. All site plans shall be submitted to NWC for review and approval.

\section{Shelters}

Lease operators shall have the option of either removing his employees from NWC upon request or retiring to NWC approved personnel shelters provided by the contractor during those times when the NWC mission requires personnel protection at the work site.

\section{Radioactive Sources}

No radioactive sources shall be brought onto NWC until appropriate Navy permits have been obtained. These permits will be issued once NWC has verified the license of the operator to be valid for the proposed effort and approved written standard procedures for use and for handling lost or damaged sources.

\section{Injuries and Accidents}

All disabling injuries occuring on NWC land will be reported within 24 hours to NWC. NWC will retain the right to suspend any operation judged by NWC to present an imminent danger to any personnel on NWC property or to government property.

\section{Electronic Radiation}

Electronic emissions will not be permitted without prior review and authorization by the NWC. Periods of emission will be coordinated with the Center and, at times, the Center may require electronic emission silence for periods of up to four hours.

\section{Plant Protection}

All well-heads shall be reveted to a degree acceptable to NWC; all wells shall be fitted with an approved below ground flow limiter; all pipe lines. with automatic flow limiters as approved by NWC and all power 
plants equipped with a hardened control room approved for continuous occupancy during NWC tests.

\section{Information}

All information on incidents involving NWC equipment and/or personnel with the geothermal operators will be released to the public by NWC or jointly by NWC and the geothermal operator. Particular attention will be given to information concerning incidents that have the potential for high public interest. Any serious injury or fatality and any geothermal blowout will be reported at once to NWC.

\section{Military/Government Property}

All military and government property found on the land surface or embedded in the land shall be left in place. NWC shall be informed of the presence of all suspected or potentially hazardous material immediately and NWC personnel will inspect and remove such material in a timely manner. In case of doubt NWC is to be called for an inspection.

\section{Data Exchange}

Data "on flow, chemistry of fluids and reservoir conditions and structure shall be provided to NWC with such data to remain proprietary for a mutually agreed time, in no case to exceed 10 years.

\section{5: ' Legal Jurisdiction}

Law enforcement on NWC lands will remain the responsibility of NWC. The use of geothermal operator employees in a guard function or the contracting by the geothermal operator for security guards on NWC lands will be subject to review and approval by NWC.

\section{Right of Inspection}

WWC shall have the right of inspection at all times to ensure and verify compliance with these constraints. 


\section{$E-2$}

Coso Geothermal EIS

Preparation Schedule
Request for proposals (RFP) to public

Preproposal conference and tour

RFP Closes

Contract Award

Draft ES distributed to public

End public review

Final ES to public

Leasing decision made

Lease Sale - issuance of noncompetitive leases
$4 / 7 / 78$

$4 / 18-20 / 78$

$5 / 19 / 78$

$9 / 8 / 78$

$3 / 13 / 80$

$5 / 8 / 80$

$10 / 28 / 80$

$11 / 25 / 80$

$1 / 20 / 81$ 
$E-3$

Preparation Plan

Contract for the Coo Geothermal Environmental Statement

Bureau of Land Management

Bakersfield District office

Bakersfield, California

February 17, 1978

Revised: March 24, 1978

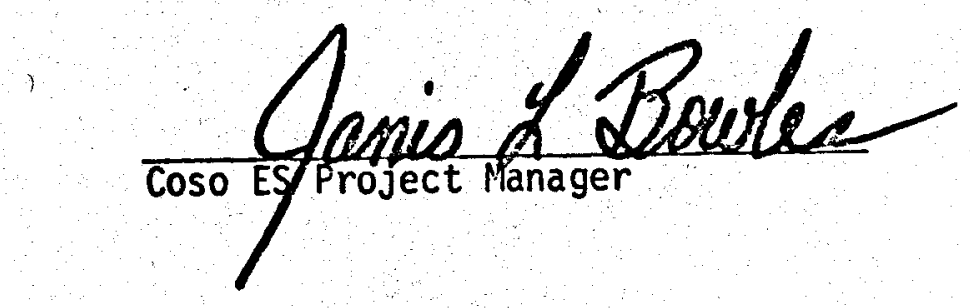


Coso Geothermal ES

Contract Preparation Plan

\section{A. Purpose of Action}

The action to be assessed by the Environmental Statement (ES) is to lease, develop, and utilize geothermal resources in and around the coso known Geothermal Resource Area. The purpose of the action is to provide electrical energy to the California power grid and to the Navy at the China Lake Naval Weapons Center (NWC). The Navy wants 25 mw to power the NWC and thus have relative independence from future potential power shortages. The rest of the power would be put into the grid and most probabily be utilized in the southern California area.

\section{B. Statement Level}

The Washington Office has given approval for preparation of an ES. The ES will be based on a quantitative geothermal development model of probably 2560 acres which will provide predictable and quantifiable impact assumptions when applied to the Coso Geothermal Study Area (CGSA). The geothermal development model will be based upon the anticipated geothermal potential of the CGSA and will quantify acres disturbed by each activity within each stage of development; roads, pipelines, drillpads; number of wells needed to power a plant, number of people employed within each stage, etc. The model will be multiplied to cover the CGSA. The resources within the CGSA will be inventoried and assessed to indicate various sensitivities and unique qualities. The development model will be applied to the sensitivity classifications, and impacts will be deduced, indicating areas where resource conflicts/ impacts are of high, medium and low significance.

\section{Study Area}

The Coso Geothermal Study Area is centered on the Coso Known Geothermal Resource Area. It includes 80,640 acres (126 sq. miles) centered on public lands administered on BLM and on lands both withdrawn and acquired by the Navy in the China Lake Naval Weapons Center (NWC). Of the total, 30,080 acres $(47 \mathrm{sq}$. mi.) are on public lands, 47,640 acres $(74.5$ sq. mi.) are withdrawn by the Navy (PLO 431) and approximately 2,999 acres ( $4.7 \mathrm{sq}$. mi.) are acquired Navy lands (see map 1, map 2). The study area reflects geothermal potential, the KGRA boundaries, and noncompetitive lease applications.

\section{Scope of the Environmental Statement}

\section{Proposed Action}

The proposed action is to lease 80,640 acres of federally administered land for development and utilization of the potential geothermal resources in and adjacent to the Coso KGRA. The leasing would occur on 


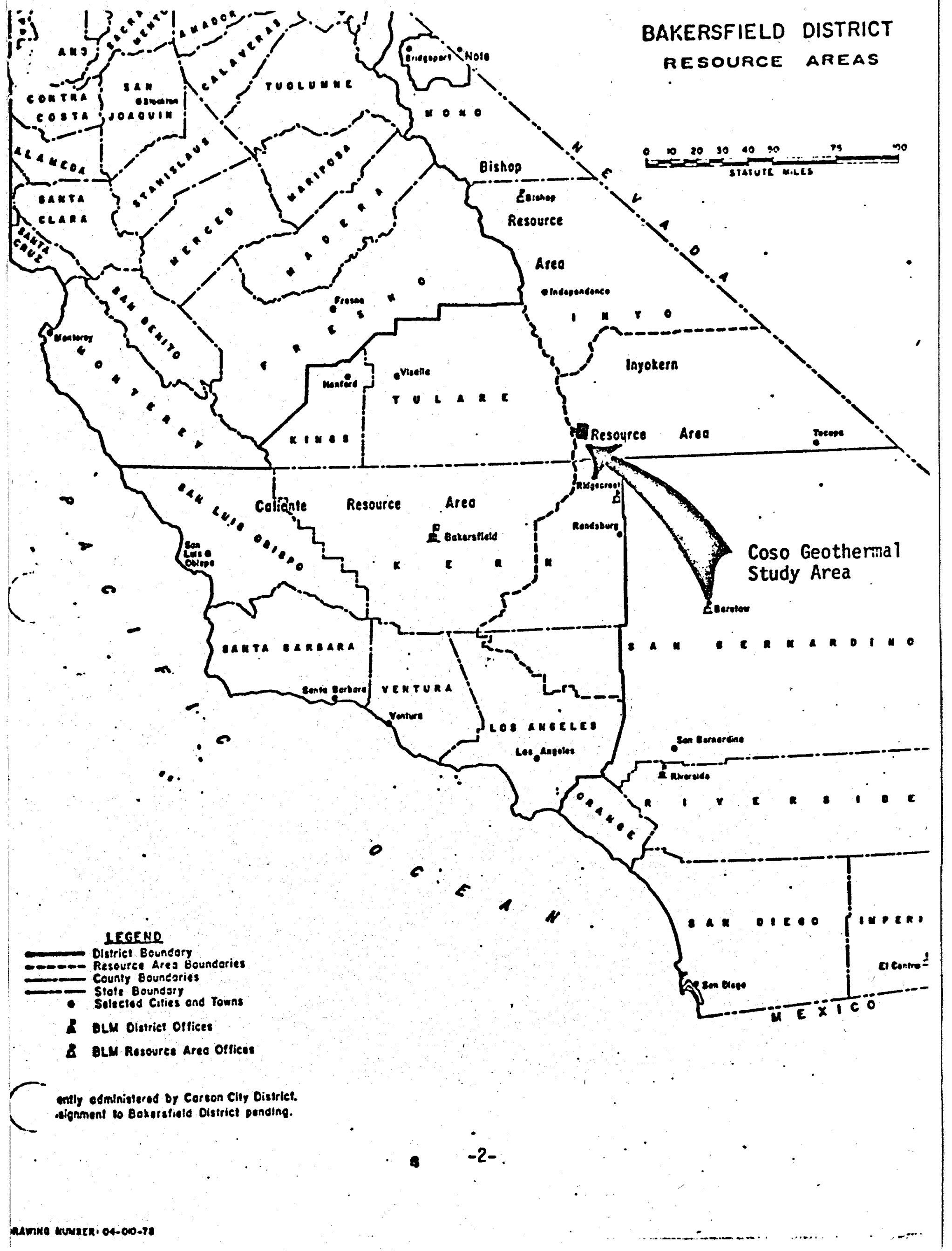




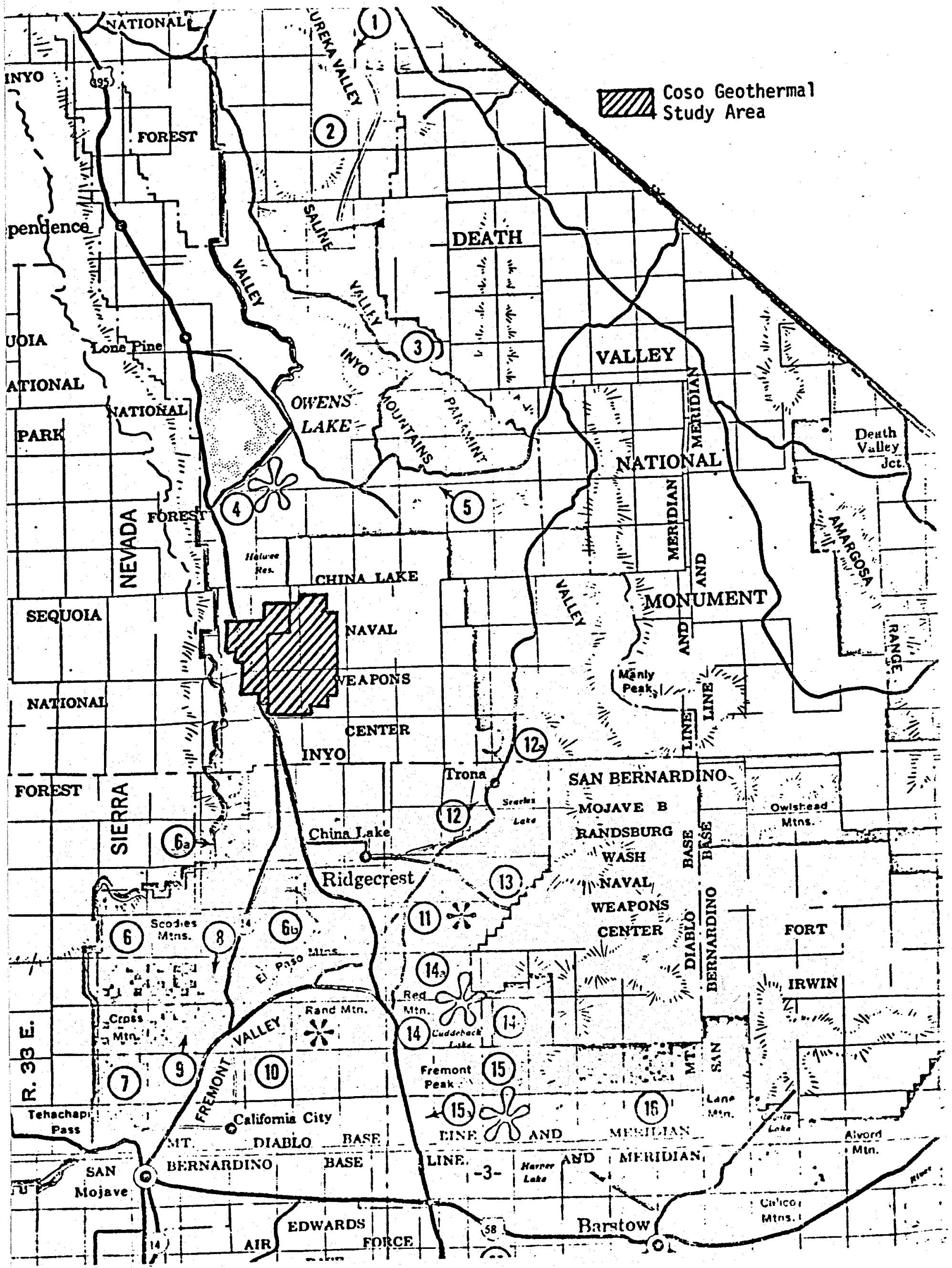


public lands administered by BLM and on lands both withdrawn and acquired by the Navy in the Naval Weapons Center.

a. Components and Stages of Geothermal Development. Although implementation of the specific action of leasing involves onty technical administrative actions, the result of leasing is a commitment to lease development through energy production. Developing the leases will have a direct impact on the natural and socio-economic environment. Therefore, this analysis deals primarily with the effects of actual geothermal development through energy production. Activities within development can be divided into five stages.

1.) Preliminary exploration. Preliminary exploration includes non-intensive uses of the land such as airborne exploration, geologic and topographic mapping, geochemical and geophysical surveys, water analyses and temperature studies, and shallow $\left(500^{\prime}+\right)$ temperature gradient holes. Some of these prel iminary exploration activities may continue through the production stage, generaliy in adjacent areas where further leases and development are anticipated.

The discrete operations are:
a) Air traffic
b) Off-road foot traffic
c) vehicular use of existing roads and trails
d) Off-road light vehicle use
e) Possible trail construction (very short distances) for temperature probe holes. Note that in practically all cases, temperature probe holes are drilled on existing roads and trails, and normally require no longer than a couple of days to complete.
f) Drilling small-diameter holes from a truck-mounted drill rig.
g) Abandonment of test holes.

2.) Exploration drilling. This is the drilling of the first few wells to determine the existence and extent of the resource.

The discrete operations are:
a) Road construction
b) Drill site construction, includes drill pad and disposal sump
c) Truck and other vehicle travel
d) Drilling
e) Well testing
f) Waste disposal, possibiy into reinjection wells
g) Well venting or bleeding
h) Abandonment

3.) Field development. This is continued drilling to prove and develop enough reserves to supply a generating plant - possibly 10 to 25 wells per section. The discrete operations are the same as 
exploration drilling but much more intensive. In addition, there are the following activities.

a) Power or utilization plant construction. This includes plants on or off-lease, and main, secondary and/or byproduct production plants.

b) Pipeline construction

c) Electric transmission line construction

4.) Production of resource (generally steam and electricity). This is continued field development plus eventual full scale operation and maintenance of facilities. The discrete operations are the same as in exploration drilling and field development, plus maintenance of existing facilities.

5.) Total close out of operations. Takes place after geothermal resources can no longer be economically extracted from the reservoir. Geothermal dry steam reservoir technology has not advanced to a stage where a reasonable economic limit can be predicted. Fields may last up to 100 years. For planning purposes, 50 years will be used, which is roughly the steam plant amortization period. Hot water fields may last indefinitely. Theoretically, with normal technological advancement the resource could last indefinitely. Close out would probably be a gradual process, occurring at differing times in various parts of the field.

The discrete operations are:
a) Abandonment of wells
b) Remoyal of surface installations and equipment
c) Surface reclamation and restoration

b. Related Actions. The statement will briefly describe those off-lease actions. related to the proposed action. These include granting rights-of-way for transmission lines and access roads, adding to the regional electrical transmission corridors and using the geothermal resources in other potential ways ranging from chemical production facilities or agribusiness to space heating. The statement will not analyse the impacts of the related actions except where some may occur in al ternatives.

\section{Possible Alternatives to the Proposed Action}

a. Decline to lease lands under consideration (No Action).

b. Lease all lands under consideration but those the development of which could create significant resource or socio-economic conflicts or impacts.

c. Lease all lands under consideration with a "no surface entry and/or disturbance stipulation on areas containing sensitive resources. This would be possible only where such lands could be developed by plant drilling from adjacent leases or private holdings. 
d. Any combination of the above alternatives applied to specific lease tracts or even to areas within a specific lease. Each combination would be developed as a specific alternative.

3. Agency Involvement

The Bureau of Land Management is the leasing agency for geothermal resources on all federal lands (Geothermal Steam Act, 1970). The Department of Navy, through the Naval Weapons Center will have approval of all stipulations on tracts offered for lease on withdrawn and acquired lands within their jurisdiction. The Naval Weapons Center will review the various drafts of the statement as they are developed.

The U. S. Geological Survey and the U.S. Fish and Wildlife Service will be consulted as stated in the CSO Instruction Memorandum 76-13, Tripartite Memorandum of Understanding on Cooperative Procedures in the Geothermal Program.

The following are agencies which have jurisdiction and/or expertise and which will be consulted.

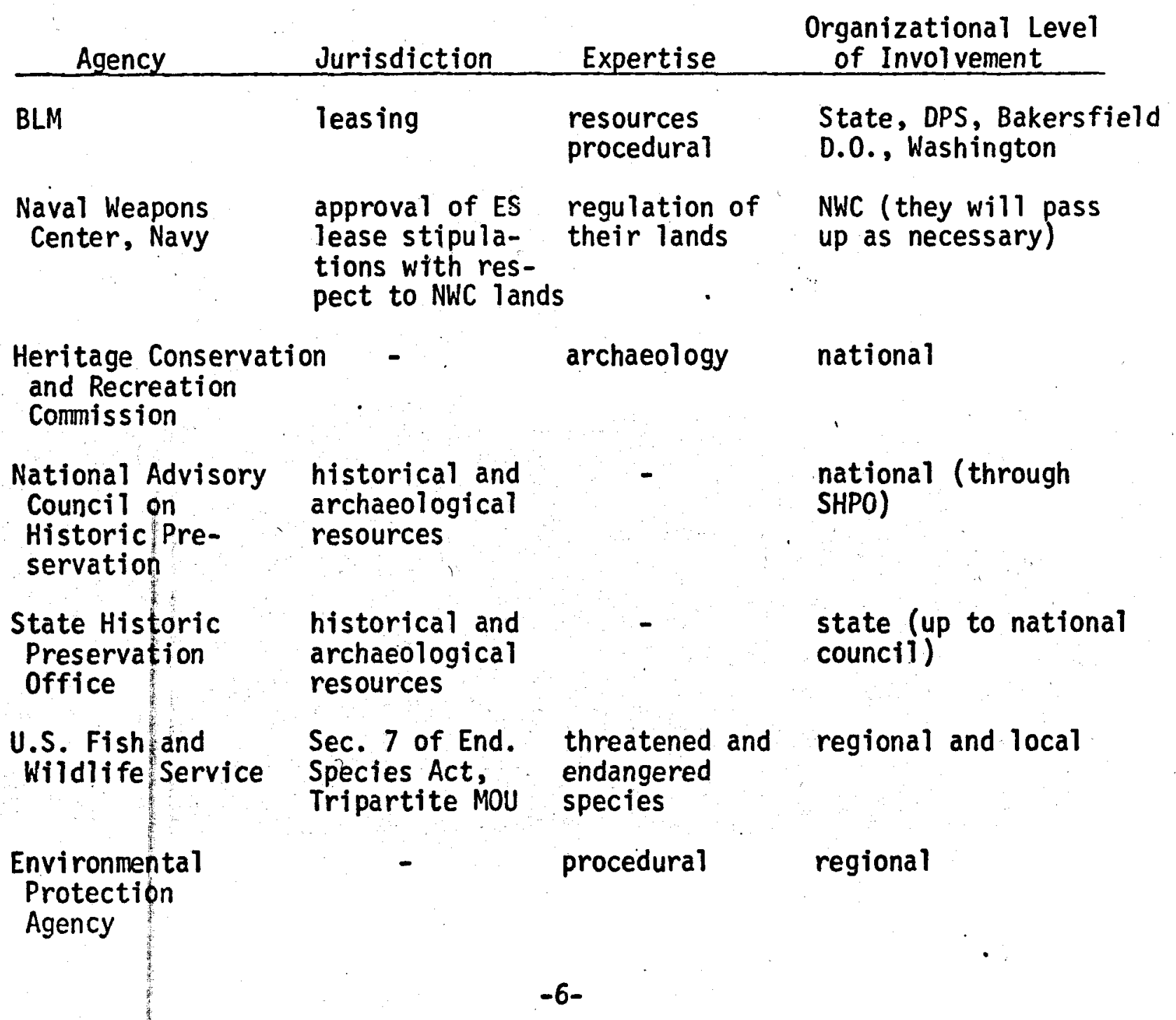




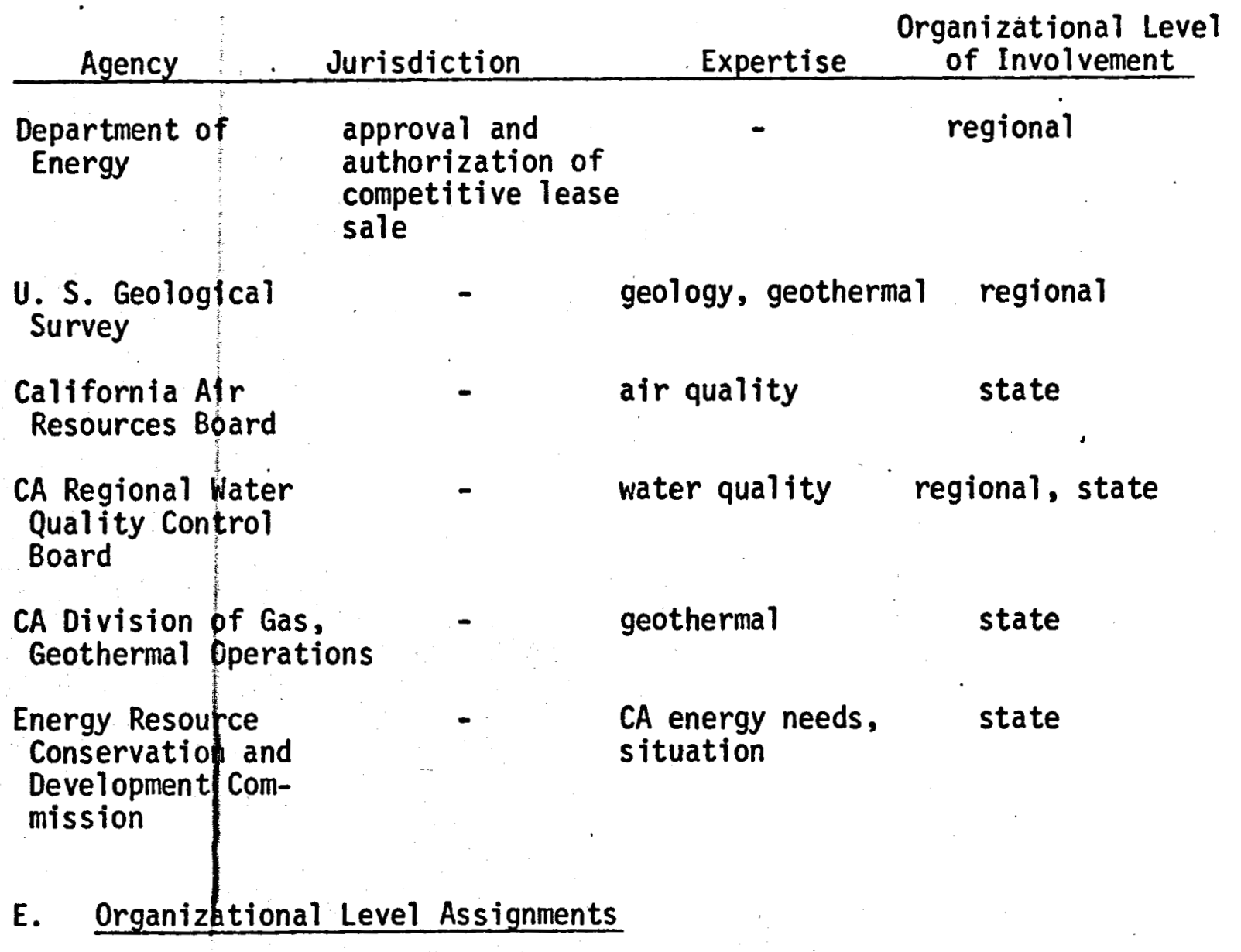

1. Organizational Level

The Environmental Statement will be contracted from the Bakersfield Office by the Denver Service Center Procurement Office. Russell Fromholtz will be the Contracting Officer from DSC. Final approval of the ES will be at the Departmental level.

\section{COAR and TPEC Team}

The Bakersfipld District Environmental Coordinator, Janis Bowles, is the Procurement Request (PR) team leader, and the Technical Proposals Evaluation Committee (TPEC) chairperson. After the contract is awarded she will function as the Contracting Officers Authorized Representative (COAR) and Project Manager.

The rest of the TPEC is composed of ten (10) persons; four (4) from the District Resources staff, one (1) from the Ridgecrest Resource Area, one (1) from the Riverside District and four (4) from the California State office. TPEC organization is shown in Figure 1. 
Figure 1

TPEC Organization

Janis Bowles

COAR/Project Manager

Ridgecrest

Resource Area

Jeff Aardah1
Bakersfield
District Resources

Helen Clough

Bert Hart

Tim Salt

Barry Phillips
California Riverside

State Office District

Roald Bendixen Dudley Smith

Torun Almere

Doug Kleinsmith

Marty Townsend

All personnel on the TPEC will manage their schedules so that when Coso duties are scheduled, there will be no conflicts. All persons must give the Coso ES project their first priority through contract award and prework conferences. In the subsequent review process, somewhat more leeway will be all owable except that review schedules will not slip. The less frequent team meetings during this phase will be more easily scheduled to accomodate the team members work loads.

The TPEC team is basically composed of one specialist per resource. Each specialist will be responsible for reviewing the Technical Proposal (s) to evaluate the handling of that particular resource, and in some cases, one or two closely related resources. The Contracting Officer and the COAR will be responsib?e for evaluating the Technical Proposal(s) for management adequacy.

The Technical Proposals Evaluation Committee is as listed.

\section{Personnel}

Russ Fromholiz

Janis Bowles

Dudley Smith

Roald Bendixen

$c_{1} c_{2}$ - Marty Townsend?

Bert Hart

Jeff Aardahl

Helen Clough

Tim Salt

Barry Phillips

Torun Almer

Doug Kleinsmith
Component

Contracting Officer

COAR Team Leader

Air Quality/Climatolugy

Geology, geologic hazards

Soils, hydrology

Vegetation (and livestock

$\&$ feral horses/burros)

Wildi ife

Cultura1/Historical Resources

Noise, overall submission

Land Uses

Socio-economics

ES technique
Office

Denver Service Center Bakersfield

Riverside

State Office

State Office

Bakersfield

Ridgecrest

Bakersfield

Bakersfield

Bakersfield

State Office

State Office

\section{Review Procedures for Deliverabies from Contractor}

The COAR will coordinate all Bureau and Navy reviews, and all review comments will be transmitted through the COAR. The TPEC will review 
all interim chapters from the contractor. Individual chapters may be reviewed by appropriate California State Office (CSO) personnel when their advice is needed; these will be transmitted to and from CSO through the COAR and the CSO TPEC members. Upon completion, Chapter 1 will be transmitted to CSO and WO Upland Minerals Environmental Assessement Staff (731), which will distribute copies to w0 and Departmental reviewers. All reviewers will then convene in Bakersfield to jointly prepare review comments and propose necessary changes. The PDES will also be reviewed by COAR, TPEC, CSO, WO, etc. following the same procedures as used for review of Chapter 1. The Departmental Solicitors Office will also review at several stages. The Naval Weapons Center will review certain of the . drafts; they will be especially concerned with mitigation measures and subsequent stipulations to prevent interference with their mission. Figure 2 shows the anticipated reviewing offices at each stage of submission.

\section{Proposed Contractor and Bureau Responsibilities}

The DSC Contracting officer and the TPEC will be responsible for conducting the evaluations to choose the contractor. This will include managing the pre-proposal conference and tour as well as the prework conference folloiwng contract award. The Bakersfield District will advise other agencies of the impending project and invite input. The District will conduct a tour for USFWS and USGS in accordance with the Tripartite Memorandum of Understanding on Geothermal. The Public Affairs Staff in the district will release news stories and arrange for two public meetings in the preliminary stages to explain the program, and two public hearings during public review of the DES.

The contractor will be responsible for collecting all information and conducting field work. The contractor will attend scheduled periodic meetings with the COAR and will submit all deliverables as specified in the contract. The contractor will make all suggested changes for the subsequent submissions. The contractor will be responsible for insuring that all submissions are coherent and edited; gramatically correct, and free from typographical errors. The graphics may be neat draft in the interim chapter submissions and in the PDES stage, but will be final in subsequent submissions.

The Bureau (all offices) and the Naval Weapons Center are responsible (through the COAR) for timely review and comments. After the cameraready draft and final ES's are submitted and approved for printing through OEPR, the Bureau will print either through GPO or NWC printing facilities. Which printer to be used will be determined by the printing load of the NWC at the time that the GPO would normally be contacted.

The public and other agencies are responsible for meeting comment deadiines. Comments will be received by the Bakersfield District Office. The policy questions will be answered by the Bureau. The informational questions will be answered by the contractor. The District will submit 
Figure 2. Review Steps in ES Process.

\begin{tabular}{|c|c|c|c|c|}
\hline $\begin{array}{c}1 . \\
\text { Chapter }\end{array}$ & & ${ }^{2}{ }^{2}$ Interim Chapters & $\begin{array}{l}3 . \\
\text { PDES } \\
\end{array}$ & $\begin{array}{l}4 . \\
\text { Compliance Review }\end{array}$ \\
\hline $\begin{array}{l}\text { COAR } \\
\text { TPEC } \\
\text { SO } \\
\text { WO } \\
\text { OEPR } \\
\text { (Solic }\end{array}$ & tor) & $\begin{array}{l}\text { COAR } \\
\text { TPEC }\end{array}$ & $\begin{array}{l}\text { COAR } \\
\text { TPEC } \\
\text { SO } \\
\text { WO } \\
\text { NWC }\end{array}$ & $\begin{array}{l}\text { COAR } \\
\text { TPEC } \\
\text { WO }\end{array}$ \\
\hline DES & & $\begin{array}{l}6 . \\
\text { Revised and Camera } \\
\text { Ready DES, copy to } \\
\text { OEPR }\end{array}$ & $\begin{array}{c}7 . \\
\text { Published } \\
\text { DES }\end{array}$ & $\begin{array}{r}8 . \\
\text { PFES } \\
\end{array}$ \\
\hline $\begin{array}{l}\text { OEPR (1s } \\
\text { review } \\
\text { clearan } \\
\text { print) }\end{array}$ & or & $\begin{array}{l}\text { COAR } \\
\text { WO (to) } \\
\text { OEPR (ciearance } \\
\text { to print) }\end{array}$ & public & $\begin{array}{l}\text { COAR } \\
\text { TPEC } \\
\text { SO } \\
\text { WO } \\
\text { NWC }\end{array}$ \\
\hline
\end{tabular}

11.

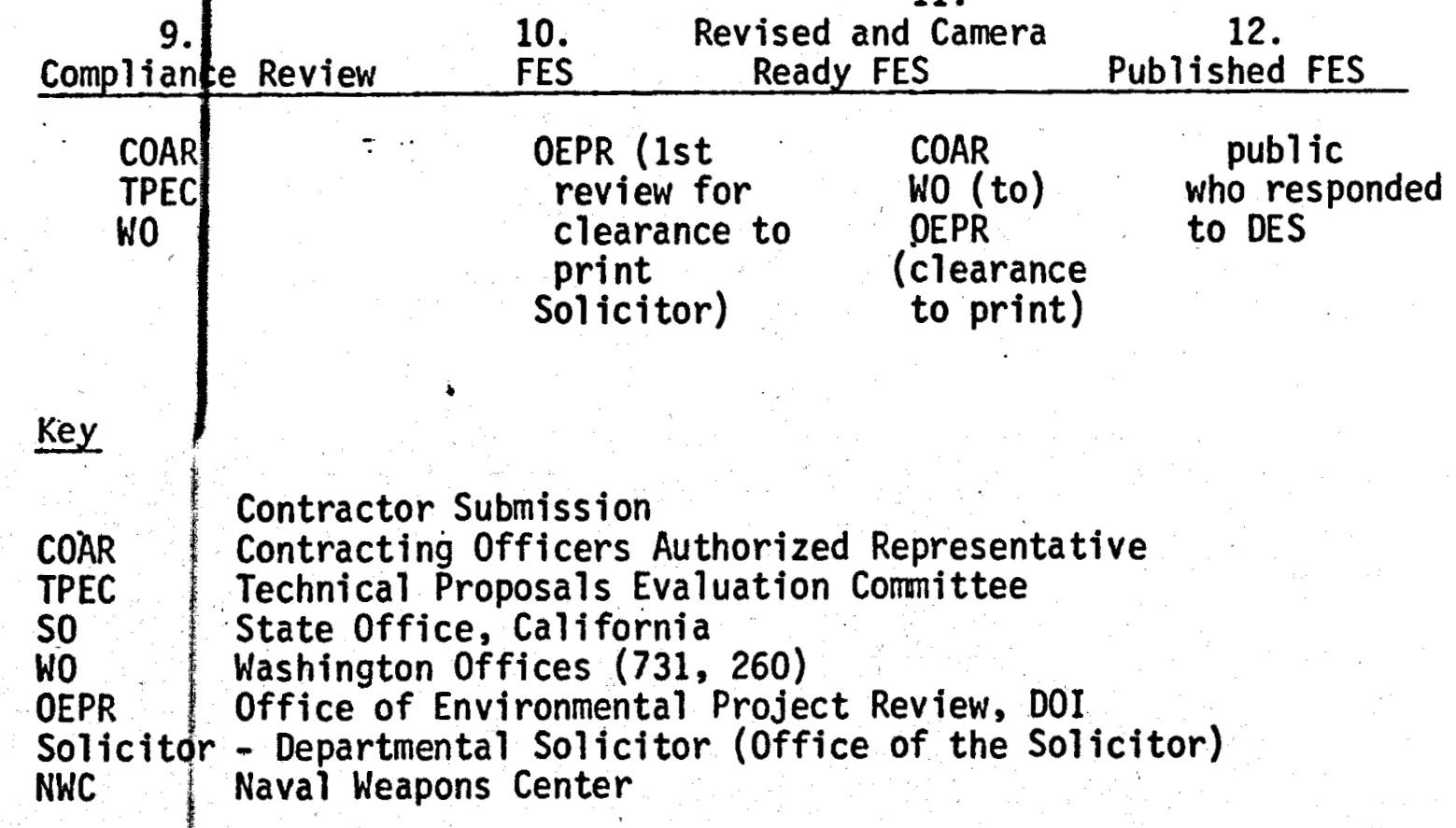


all comments and answers to those which are answered by BLM to the contractor. The contractor will address and compile in the PFES all comments, and make textual changes as appropriate.

The Bureau will make final payment to the contractor when all obligations of the contractor have been fulfilled.

\section{Discussion of Potential Problems}

a. The Technical Proposals received by the bidders on the Coso RFP may very well run over the $\$ 500,000$ allotted to the contractor. A possible solution is additional funding in later fiscal years of the project schedule.

b. The Bakersfield District TPEC members will have program conflicts in the coming years.

1.) Benton-Owens Valley inventory in FY 78

2) Benton-Owens Valley URA 1-4 MFP 1-2 in FY 79, and $\mathrm{ES}$ in FY $80,81$.

3) Bodie/Coleville PU inventory in FY 79, URA 1-4, MFP $1-2$ in FY 80.

4). Kernville PU inventory in FY 80 . All of the above projects will be led by the same Resources staff players as are in the TPEC team.

5) The TPEC members will also be coordinating with the Desert Plan Staff in the URA-MFP stage in late FY 78-79.

c. There appear to be roadless areas of over 5,000 acres within the public lands portion of the Coso Geothermal Study Area. The presence of roadless areas within the CGSA will complicate mitigation measures and lease stipulations. Definitive guidance will be necessary to insure adequate consideration of wilderness potential.

\section{F. Statement Outline}

The following statement outline is anticipated to be the basis upon which the contractor will add or delete. At this time, we cannot anticipate how the eventual contractor will propose to organize the document, especially the analys is of impacts. One of the points upon which contract award will be made will be the proposed outline submitted in each bidder Technical Proposal. Consequently, the outline in this section goes no further than the basic headings after Chapter 2.

\section{Table of Contents}

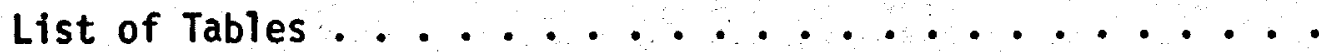

List of Figures 
List of Maps

Introduction

I. PROPOSED ACTION

A. Purpose

B. Regulatory Constraints ............

C. Geothermal Development Model ..........

1. Stages of Implementation .........

2. Lease Size and Project Facilities.......

3. Surface Disturbance . . . . . . . . .

4. Fluid Production and Associated Wastes

D. Interrelationships

II. DESCRIPTION OF THE EXISTING ENVIRONMENT

A. Existing Environment ............

1. Air Quality/Cl imatology ..........

a. Quaitity ...........

b. Climatology ............

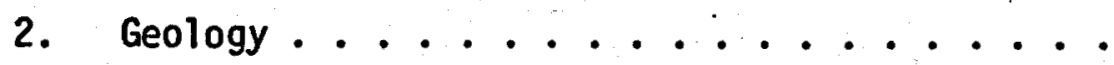
a. Local Topography and Geology ......
b. Geologic Hazards
c. Geothermal Potential
d. Economic Mineral Commodities other than

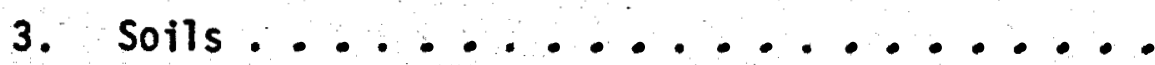

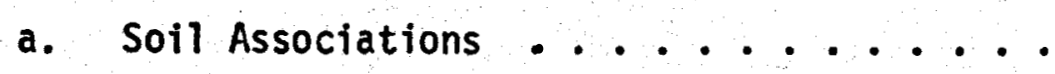

b. Soil Interpretive Ratings

4. Water.

1

a. Hydrologic Cycle 
b. Surface water ...........

c. Ground water .............

d. Influence of Geologic Structure on Surface and Ground Water............

e. Recharge and Movement of Ground Water ...

f. Ground Water Storage ..........

g. Water Quality Surface and Ground ......

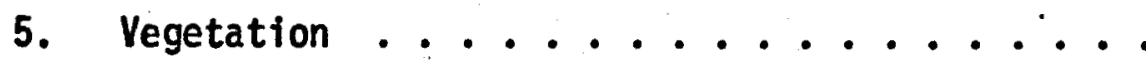

a. Vegetative Polygons (plant associations) and associated species ...........

1. Aquatic/riparian

2. terrestrial

b. Sensitive Habitats and Associated Species.

c. Threatened and Endangered Species ....

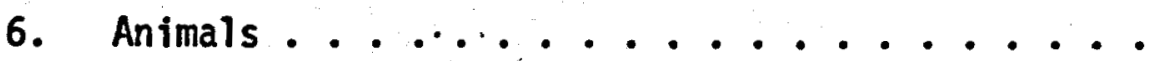

a. Habitat Types and Associated Species ....

b. Endangered, Threatened and Significant Species

c. Sensitive Habitats and Associated Species.

d. Domestic livestock ...........

e. Feral Horses and Burros .........

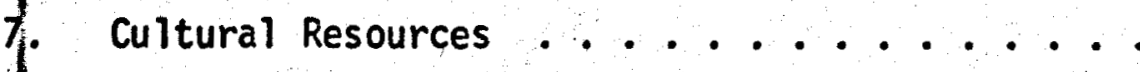

a. Background (Prehistoric Ethnographic and Historic)

b. Field Survey strategy ..........

c. Results of Inventory ..........

*Above three sections abbreviated forms of 106 Cultural Resources Compliance Report. 
d. Cultural Resources Sensitivity ......

8. Visual Resources .............

*To be prepared by District and submitted to contractor for inclusion

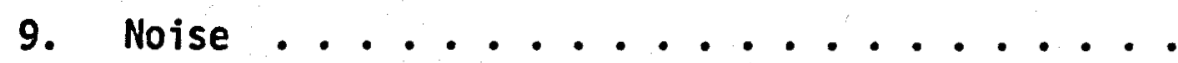

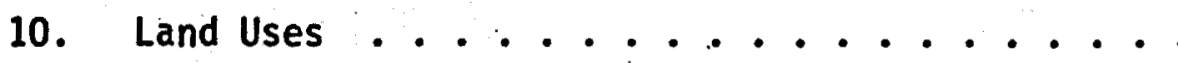
a. Land Status .............
b. Naval Weapons Center military uses .....
c. Recreation
d. Livestock
e. Mineral Resources (resource base and use)..
f. Wilderness .............
* to be prepared by District and submitted to contractor for inclusion. Contractor will propose mitigating measures.

g. Land use plans, controls, constraints (Federal, State, Local) ............

h. Other

11. Transportation Networks (types and use)

a. Electrical Transmission Corridors ......

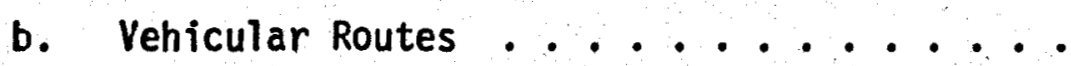

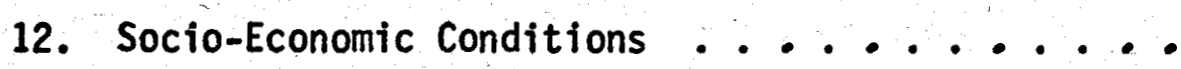

a. Population Characteristics ........

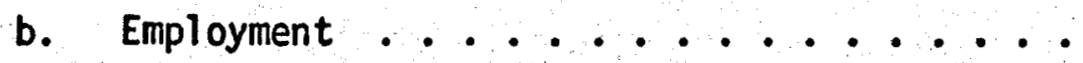

c. Income . . . . . . . . . . .

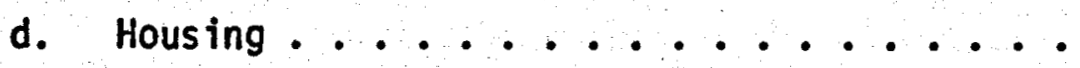

e. Education

f. Land Ownership and Use 
g. Socio-Cultural values .........

h. Public Attitudes and Expectations re: proposal ............

i. Infrastructure ...........

1) Police, fire protection .......

2) Utility services-gas, electricity, water, sewage, solid waste ......

3) Health system/Mental health .....

4) Education system ..........

5) Social services ..........

6) Community facilities-parks, recreation, organizations, "cultural" .......

j. Public finance and tax base facilities...

k. Social well-being (citizen perception) ...

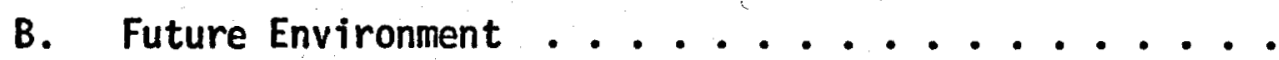

(same categories as Existing Environment where changes are expected to occur)

III. THE ENVIRONMENTAL IMPACTS OF THE PROPOSED. ACTION

A.- Assumption and Analys is Guidelines

B. Impacts from Geothermal Development Model when applied

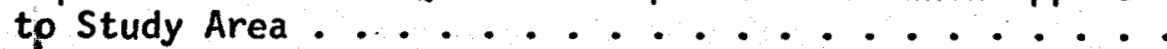

1. Air Quality

2) Geology

3. Soils

4. Water

5. Vegetation

6. Animals

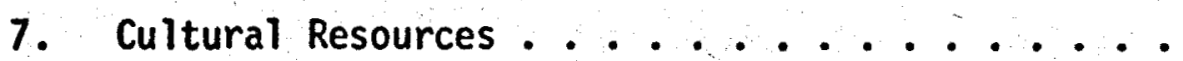

8. Visual Resources ............. 


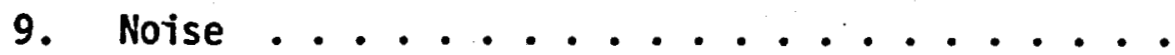

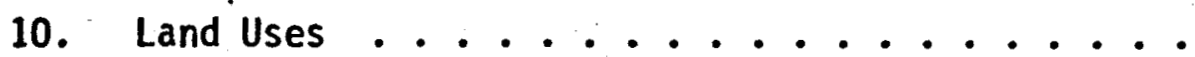

11. Socio-Economic Conditions ..........

IV. MITIGATION MEASURES NOT INCLUDED IN THE PROPOSED ACTION ...

V. ADVERSE IMPACTS WHICH CANNOT BE AVOIDED SHOULD THE PROPOSAL BE IMPLEMENTED .................

VI. RELATIONSHIP BETWEEN LOCAL SHORT-TERM USES AND MANS

ENVIRONMENT AND THE MAINTENANCE AND ENHANCEMENT OF LONG-TERM

PRODUCTIVITY $\ldots \ldots$

VII. IRREVERSIBLE AND IRRETRIEVABLE COMMITMENTS OF RESOURCES

WHICH WOULD BE INVOLVED IN THE PROPOSED ACTION SHOULD IT

BE IMPLEMENTED .................

VIII ALTERNATIVES TO THE PROPOSED ACTION ...........

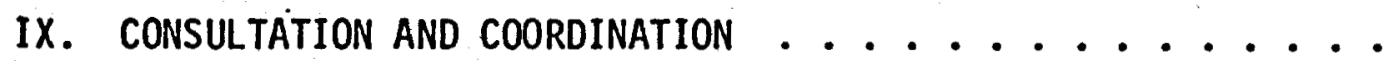

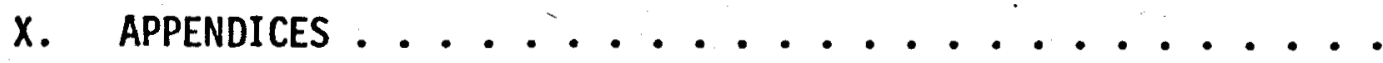

G. Preparation Schedule

Calendar

days/weeks Deadlines

1. Revised (SO, WO review) Preparation Plan to State Director

$2 / 10 / 78$

2. Preparation Plan Sent to Washington Office

1 week $2 / 17 / 78$

3. Washington Office Approves Preparation Plan

1 week $2 / 24 / 78$

4. Procurement Request (revised) sent to so

1 weeks $3 / 3 / 78$

5. State Office approves PR sends to DSC

1 week $3 / 10 / 78$

6. Work on Request for Proposals (RFP) culminates and RFP issued by BSC.

7. Pre-proposals conference

after 2 weeks 2 days

8. RFP closes

6 weeks

$5 / 19 / 78$

9. Tech. Proposals evaluations end, Contract 16 weeks Award

$9 / 8 / 78$ 
10. Prework conference

11. Contractor Submits Chapter 1

12. DO, SO, WO, OEPR, geothermal Solicitor Navy complete Chapter 1 review

13. Data collection and submission of interim chapters

14. Contractor submits, PDES

15. DO, SO, WO, Navy complete PDES review

16. Contractor Submits revised PDES

17. DO, SO, Wo compliance review of revised PDES 1 week

18. WO sends PDES to OEPR (Solicitor)

19. OEPR (Solicitor) completes PDES review

20. Contractor finishes revision and submits camera-ready DES to COAR

21, OEPR gives ciearance to print

22. COAR submits camera-ready DES to GPO

23. DES printed and distributed

24. End public review

25. Contractor Submits PFES

26. DO, SO, WO, Navy complete PFES review

27. Contractor submits revised PFES

28. DO, SO, WO compliance review of revised PFES

29. Wo sends PFES to OEPR

30. OEPR completes PFES review

31. Contractor finishes revision and submits camera-ready FES to COAR

32. OEPR gives clearance to print
2 weeks 9/19-22/78

1 month $10 / 20 / 78$

2 weeks 10/3/78

up to $19 / 22 / 78-$

year $9 / 21 / 79$

$9 / 21 / 79$

2 weeks 10/5/79

6 weeks $11 / 16 / 79$

1 day $11 / 23 / 79$

2 weeks $12 / 7 / 79$

3 weeks $12 / 28 / 79$

10 days $1 / 7 / 80$

3 days $\quad 1 \neq 10 / 80$

7 weeks $2 / 28 / 80$

8 , weeks $4 / 24 / 80$

6 weeks $6 / 5 / 80$

1 week $6 / 12 / 80$

2 weeks $6 / 26 / 80$

1 week $7 / 3 / 80$

4 days $\quad 7 / 7 / 80$

1 week $7 / 14 / 80$

2 weeks $7 / 28 / 80$

1 week $8 / 4 / 80$ 
33. COAR submits camera ready FES to printer

34. FES printed and distributed

35. DO and SO prepare Program Decision Option Document

36. State Director's decision

37. Lease Sale (1st $\frac{1}{2}$ FY 81) and issuance of non-competitive leạses
1 day $8 / 5 / 80$

7 weeks $4 / 23 / 80$

2 weeks $10 / 7 / 80$

2 weeks 10/21/80

8 weeks $12 / 16 / 80$

\section{H. Public Invol vement Arrangeinents}

The following public involvement arrangements are being planned. Their occurrance will be incoroporated into the appropriate steps of the preparation schedule.

1. Between Step 5-6. Agencies listed in 0.2 of this plan will be notified by letter. They will be requested to give input they feel would be helpful. Certain agencies will be invited to participate in an orientation tour of the Coso Geothermal Study Area provided for USGS and USFWS per Tripartite MOU.

2. Between Step 6-8. General media release discussing Coso Geothermal ES, proposed contract, etc.

3. Step 7. Pre-proposal conference for bidders. This will be arranged to take place at the Naval Weapons Center in Ridgecrest. An agenda will be developed to cover points which the bidders may not ask. The conference will be followed by an orientation tour of the coso Geothermal Study Area for those bidders so inclined.

4. Between Step 9-13. A media release will generally discuss the award of contract and commencement of work, etc.

5. Between Step 9-13. A geothermal awareness program will be initiated at this point. It will include the following:

Pine.

a. Two public meetings, probably in Ridgecrest and Lone

b. Newsletter mailing. Coso will be discussed in the District Newsletters (to public and internal).

printed.

c. A brochure on geothermal resources will be developed and

d. Television appearances will be arranged for general news purposes. 
tations:

e. The Coso project will be integrated into district presen-

f. The general awareness media releases will be developed periodically throughout this time.

6. Between Step 23-24. The Draft Environmental Statement will be distributed, and a general media release will describe how interested persons may obtain a copy.

7. Between Step 23-24. The DES distibution will be discussed in the District Newsletters. Two public hearings on the DES will be held.

8. Between Step 34-37. Media releases on FES distribution, State Director's decision, and lease sale. 